\title{
A Synthetic Approach to Dimetallated Arenes Using Flow Microreactors and the Switchable Application to
}

Chemoselective Cross-Coupling Reactions

Yosuke Ashikari, Tomoko Kawaguchi, Kyoko Mandai, Yoko Aizawa, and Aiichiro Nagaki*

index

1. General Remarks

2. Halogen-Lithium Exchange Reaction of 4-Bromophenylboronic Acid Pinacol Ester Followed by Reaction of Tri-n-Butylthin Chloride in a Flow Microreactor (Negative Control)

3. Generation of Lithium Arylboron-ate Complex 4 in a Flow Microreactor

4. Reactions of Lithium Arylboron-ate Complexes in a Flow Microreactor

5. Cross Coupling Reactions of Bimetallic Arenes

6. Synthetic Utility of Stannyl Biphenyl 11 and Boryl Biphenyl 12.

7. References

8. ${ }^{1} \mathrm{H}$ and ${ }^{13} \mathrm{C}$ NMR Spectra

\section{General Remarks.}

Abbreviations. atmospheric pressure chemical ionization (APCI), approximately (approx.), aqueous (aq.), aryl (Ar), boron trifluoride ethyl diether complex $\left(\mathrm{BF}_{3} \cdot \mathrm{OEt}_{2}\right)$, broad (br), butyl $(\mathrm{Bu})$, degrees Celsius $\left({ }^{\circ} \mathrm{C}\right)$, calculated $($ calcd), deuteritated chloroform $\left(\mathrm{CDCl}_{3}\right)$, centimeter(s) $(\mathrm{cm})$, doublet (d), dimethyl sulfoxide (DMSO), deuteritated dimethyl sulfoxide (DMSO- $\left.d_{6}\right)$, 1,1'bis(diphenylphosphino)ferrocene (dppf), electron ionization (EI), equivalent (equiv or eq), electrospray ionization (ESI), ethyl acetate (EtOAc), gram(s) (g), gas chromatography (GC), hour(s) (h), high resolution mass-spectrometry (HRMS), hertz (Hz), isopropyl ( $i \operatorname{Pr}$ ), coupling constant $(J)$, length of tubes $(\mathrm{L})$, liter(s) $(\mathrm{L})$, mol $\mathrm{L}^{-1}$ of molar concentration $(\mathrm{M})$, multiplet $(\mathrm{m})$, methyl $(\mathrm{Me})$, metallic atom (Met), deuteritated methanol (methanol- $\left.d_{4}\right)$, milligram(s) (mg), megahertz (MHz), minute(s) (min), milliliter(s) $(\mathrm{mL})$, millimole $(\mathrm{s})(\mathrm{mmol})$, mole(s) (mol), normal $(n), \mathrm{mol} \mathrm{L}^{-1}$ of equivalent concentration $(\mathrm{N})$, nuclear magnetic resonance $(\mathrm{NMR})$, para (p), dichloro-[1,3-bis(diisopropylpenyl)-2-imidazolidinyliden]-(3-Chloropyridyl)palladium (II) (PEPPSI-SIPr), pinacol boranyl group (pinB), tetramethylethylenedioxy group (pin), parts per million (ppm), polytetrafluoro-ethylene or Teflon (PTFE), quartet $(\mathrm{q})$, retention factor for TLC $\left(R_{\mathrm{f}}\right)$, room temperature $\left(25 \pm 3{ }^{\circ} \mathrm{C}\right.$, rt), secondary $(s$ or $s e c)$, second(s) $(\mathrm{s})$, singlet $(\mathrm{s})$, saturated (sat.), septet (sept), triplet ( $\mathrm{t})$, tertiary ( $t$ or tert), tri- $n$-butylammonium fluoride (TBAF), 1,1,2,2-tetrachloroethane (TCE), tetrahydrofuran (THF), thin layer chromatography (TLC), tetramethylsilane (TMS), residence time of microtube reactor $\mathrm{Rn}\left(t^{\mathrm{Rn}}\right)$, volume ratio of two solvents $(\mathrm{v} / \mathrm{v})$, chemical shift in ppm downfield from TMS $(\delta)$, inner diameter of tubes and mixers $(\phi)$, microliter(s) $(\mu \mathrm{L})$, micrometer(s) $(\mu \mathrm{m})$.

General. ${ }^{1} \mathrm{H}$ and ${ }^{13} \mathrm{C}$ NMR spectra were recorded in on Varian MERCURY plus-400 $\left({ }^{1} \mathrm{H} 400 \mathrm{MHz},{ }^{13} \mathrm{C} 100 \mathrm{MHz}\right)$, or on JEOL ECA-600P spectrometer $\left({ }^{1} \mathrm{H} 600 \mathrm{MHz},{ }^{13} \mathrm{C} 150 \mathrm{MHz}\right)$. Chemical shifts are recorded using TMS (0.0 ppm) or solvent (DMSO: 2.50 ppm) signals as an internal standard for ${ }^{1} \mathrm{H} N M R$, and methin signal of $\mathrm{CHCl}_{3}$ for ${ }^{13} \mathrm{C}$ NMR (77.0 ppm) unless otherwise noted. Because of a quadrupolar moment of naturally-occurring boron isotopes $\left({ }^{10} \mathrm{~B}\right.$ and $\left.{ }^{11} \mathrm{~B}\right),{ }^{13} \mathrm{C}$ NMR signal of a carbon directly attached to a boron atom becomes significantly broad, and often becomes invisible in the chart. ${ }^{[1]}{ }^{11} \mathrm{~B}$ NMR spectra were recorded on JEOL ECA-500P spectrometer (160 MHz) using $\mathrm{BF}_{3} \cdot \mathrm{OEt}_{2}$ in $\mathrm{CDCl}_{3}$ as an external standard ( $\left.0.0 \mathrm{ppm}\right)$. For ${ }^{11} \mathrm{~B}$ NMR analyses, 
a quartz NMR tube was used. NMR yields were calculated by ${ }^{1} \mathrm{H}$ NMR analyses using TCE as an internal standard. GC analysis was performed on a SHIMADZU GC-2014 gas chromatograph equipped with a flame ionization detector using a fused silica capillary column (column, CBP1; $0.22 \mathrm{~mm}$ x $25 \mathrm{~m}$ ). GC yields were calculated by GC analyses with $n$-tetradecane as an internal standard using calibration lines derived from commercial or isolated compounds with the internal standards. Mass spectra were obtained on Thermo Fisher Scientific EXACTIVE plus (ESI and APCI) and JEOL JMS-700 (EI). Merck pre-coated silica gel F 254 plates (thickness $0.25 \mathrm{~mm}$ ) were used for TLC analyses. Flash chromatography was carried out on a silica gel (Kanto Chem. Co., Silica Gel N, spherical, neutral, 40-100 $\mu \mathrm{m})$. All batch reactions were carried out in a flame-dried glassware under argon atmosphere unless otherwise noted.

Flow Synthesis. Stainless steel (SUS304) T-shaped micromixers with inner diameter of $500 \mu \mathrm{m}$ and $250 \mu \mathrm{m}$ were manufactured by Sanko Seiki Co., Inc. Stainless steel (SUS316) microtube reactors with $1000 \mu \mathrm{m}$ inner diameter were purchased from GL Sciences. PTFE tube with inner diameter of $1000 \mu \mathrm{m}$ was purchased from ISIS Co, Ltd. The syringe pumps (Harvard Model PHD 2000 or PHD ULTRA) equipped with gastight syringes (purchased from SGE) were used for introduction of the solutions into the micromixer systems via stainless steel fittings (GL Sciences, 1/16 OUW). Flow microreactor system is composed with stainless steel pre-cooling units (P1, P2, etc.), stainless steel microtube reactors (R1, R2, etc.), T-shaped micromixers (M1, M2, etc.), and, if necessary, PTFE tube with inner diameter of $1000 \mu \mathrm{m}$. The solution of $n$-butyllithium and sec-butyllithium was prepared by dilution of those commercial solution with dehydrated $n$-hexane.

Materials. Dehydrated THF and $n$-hexane were purchased from FUJIFILM Wako Pure Chemical Corporation, and were used without further purification. A solution of sec-butyllithium (in cyclohexane and $n$-hexane, $1.03 \mathrm{M}$ ) was purchased from Kanto Chemical Co., Inc. and stored at $-20^{\circ} \mathrm{C}$. A solution of zinc chloride (in THF, 1.0 M) was purchased from FUJIFILM Wako, and was diluted with dry THF. 2-(4-Bromophenyl)-4,4,5,5-tetramethyl-1,3,2-dioxaborolane (1), 1,4-dibromobenzene (3a), 1,3dibromobenzene (3b), 1,3,5-tribromobenzene (3c), 2,5-dibromothiophene (3e), 2,3-dibromopyridine (3f), 2,5-dibromopyridine (3g), 2,2'-dibromobiphenyl (3h), B(OiPr)pin, $\mathrm{B}(\mathrm{O} i \mathrm{Pr})_{3}, \mathrm{~B}(\mathrm{OMe})_{3} \mathrm{Bu}_{3} \mathrm{SnCl}$, 1,4-benzenediboronic acid bis(pinacol) ester (9a-B), 1,3benzenediboronic acid bis(pinacol) ester (9b-B), biphenyl (15), 4-cyanobiphenyl (17), and aryl iodides were purchased from commercial suppliers. tert-butyl 3,5-dibromobenzoate (3d) was synthesized according to the reported procedure. ${ }^{[2]}$

\section{Halogen-Lithium Exchange Reaction of 4-Bromophenylboronic Acid Pinacol Ester Followed by Reaction of Tri- $n$-Butylthin Chloride in a Flow Microreactor (Negative Control).}
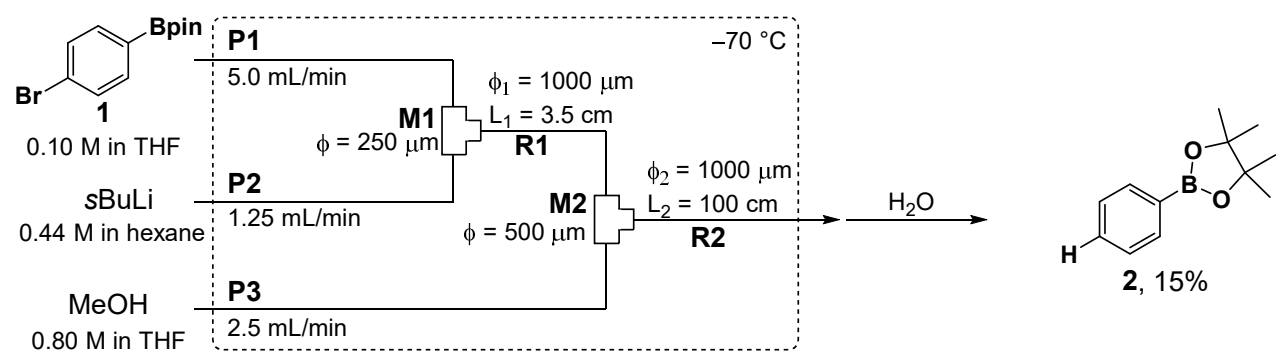

A flow microreactor system consisting of two T-shaped micromixers (M1 and M2), two microtube reactors (R1 and R2), and three pre-cooling units $(\mathbf{P} 1(\mathrm{~L}=100 \mathrm{~cm}), \mathbf{P 2}(50 \mathrm{~cm})$ and $\mathbf{P 3}(50 \mathrm{~cm}))$ was used in a cooling bath at $-70{ }^{\circ} \mathrm{C}$. A solution of $4-$ bromophenylboronic acid pinacol ester $(1,0.10 \mathrm{M}$ in THF, flow rate: $5.0 \mathrm{~mL} / \mathrm{min})$ and a solution of $s$ BuLi $(0.44 \mathrm{M}$ in hexane, flow rate: $1.25 \mathrm{~mL} / \mathrm{min})$ were introduced to $\mathbf{M 1}(\phi=250 \mu \mathrm{m})$ using syringe pumps, and the mixture was passed through R1 $(3.5 \mathrm{~cm}$, residence time $\left.t^{\mathrm{R} 1}=0.26 \mathrm{~s}\right)$. The resulting solution was introduced to $\mathbf{M} 2(\phi=500 \mu \mathrm{m})$, where a solution of methanol $(0.80 \mathrm{M}$ in THF) was also introduced (flow rate: $2.50 \mathrm{~mL} / \mathrm{min})$. The resulting solution was passed through $\mathbf{R 2}(\phi=1000 \mu \mathrm{m}, \mathrm{L}=100 \mathrm{~cm}$, 
residence time $=5.4 \mathrm{~s}$ ). After a steady state was reached, the product solution was collected for 30 seconds. To the aliquot, sat. $\mathrm{NH}_{4} \mathrm{Cl}$ aq., EtOAc, and $n$-tetradecane were added, and then the organic phase was analyzed by GC, which indicated the yield of phenylboronic acid pinacol ester (2) was $15 \%$ and conversion of 1 was $83 \%$.

\section{Generation of Lithium Arylboron-ate Complex 4 in a Flow Microreactor.}

3-1. Halogen-Lithium Exchange Reaction of 1,4-Dibromobenzene (3a) Followed by the Reaction with triisopropyl borate in the Flow Microreactor System

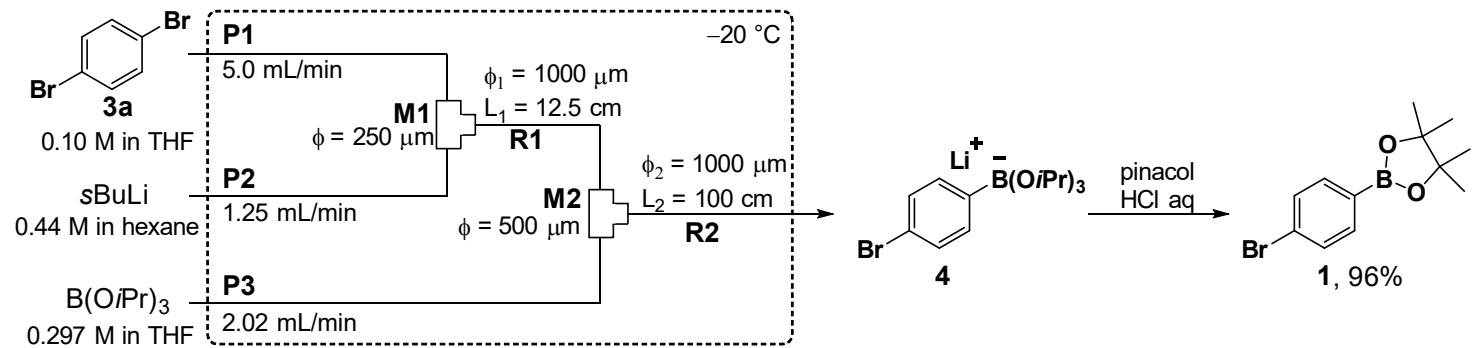

A flow microreactor system consisting of two T-shaped micromixers (M1 and M2), two microtube reactors (R1 and R2), and three pre-cooling units $(\mathbf{P 1}(100 \mathrm{~cm}), \mathbf{P 2}(50 \mathrm{~cm})$ and $\mathbf{P 3}(50 \mathrm{~cm}))$ was used in a cooling bath at $-20^{\circ} \mathrm{C}$. A solution of 1,4 -dibromobenzene (3a, $0.10 \mathrm{M}$ in THF, flow rate: $5.0 \mathrm{~mL} / \mathrm{min})$ and a solution of $s \mathrm{BuLi}(0.44 \mathrm{M}$ in hexane, flow rate: $1.25 \mathrm{~mL} / \mathrm{min})$ were introduced to $\mathbf{M 1}(\phi=250 \mu \mathrm{m})$ using syringe pumps, and the mixture was passed through $\mathbf{R} 1\left(12.5 \mathrm{~cm}\right.$, residence time $\left.t^{\mathrm{R} 1}=0.90 \mathrm{~s}\right)$. The resulting solution was introduced to $\mathbf{M} 2(\phi=500 \mu \mathrm{m})$, where a solution of triisopropyl borate $(0.297 \mathrm{M}$ in THF) was also introduced (flow rate: $2.02 \mathrm{~mL} / \mathrm{min})$. The resulting solution was passed through $\mathbf{R} 2\left(\phi=1000 \mu \mathrm{m}, \mathrm{L}=100 \mathrm{~cm}, t^{\mathrm{R} 2}=5.7 \mathrm{~s}\right)$. After a steady state was reached, the product solution (lithium triisopropyl 4-bromophenylborate, 4) was taken into a $100 \mathrm{~mL}$ round-bottomed flask. An

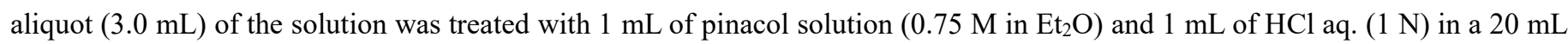
round-bottomed flask. The reaction mixture was stirred at r.t. for $30 \mathrm{~min}$. The GC analysis indicated 4-bromobenzeneboronic acid pinacol ester (1) was obtained in 96\% yield ( $n$-tetradecane was used as an internal standard).

\section{3-2. ${ }^{11 B}$ NMR analyses of Arylboron-ate Complex 4.}

The aliquot of the solution of $4(3.5 \mathrm{~mL}, 0.2 \mathrm{mmol})$ was concentrated under reduced pressure. Thus-obtained white solid was dissolved in $0.7 \mathrm{~mL}$ of methanol- $d_{4}$, and the solution was analyzed by ${ }^{11} \mathrm{~B} \mathrm{NMR}$, which showed a singlet peak on $4.7 \mathrm{ppm}$.

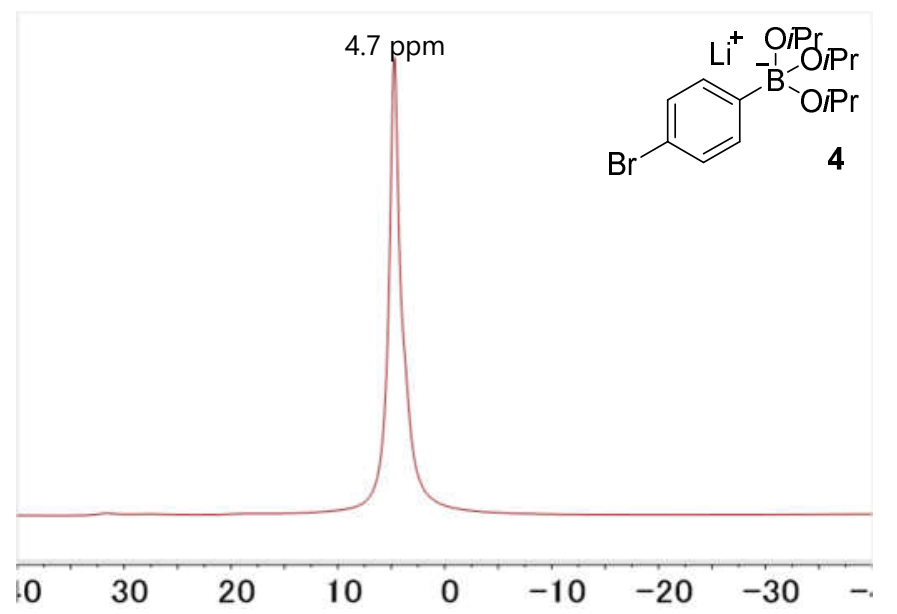

${ }^{11} \mathrm{~B}$ NMR spectrum of lithium triisopropyl 4bromophenylborate (4) (160 MHz, $\left.\mathrm{CD}_{3} \mathrm{OD}\right)$

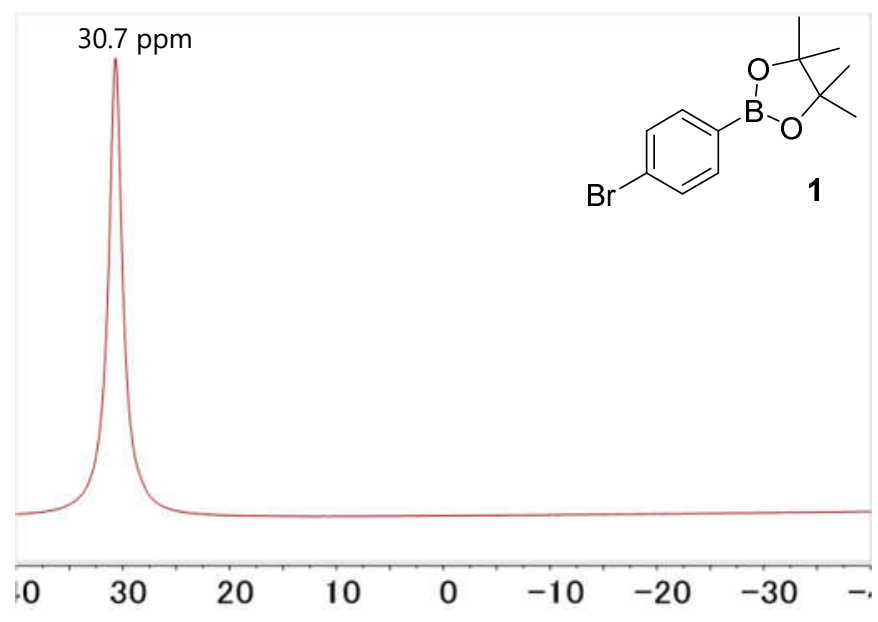

${ }^{11} \mathrm{~B}$ NMR spectrum of 4-bromophenylboronic acid pinacol ester (1) (160 MHz, $\left.\mathrm{CD}_{3} \mathrm{OD}\right)$ 


\section{Reactions of Lithium Arylboron-ate Complexes in a Flow Microreactor.}

4-1. Halogen-Lithium Exchange Reaction of Lithium Arylboron-ate Complex 4 Followed by the Reaction with Methanol in a Batch Reactor.

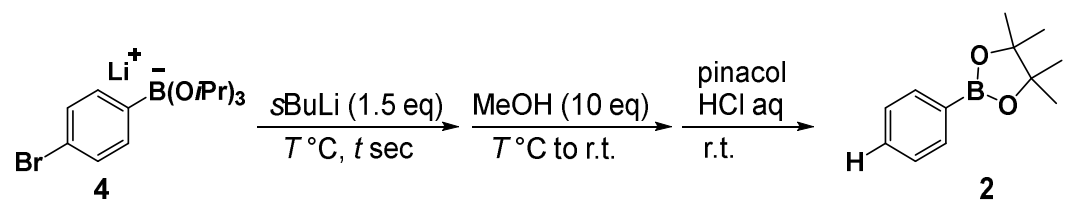

The solution of 4 was collected in a flame dried $20 \mathrm{~mL}$ round-bottomed-flask for 30 seconds (approx. $4.1 \mathrm{~mL}, 0.25 \mathrm{mmol}$. See section 3 of SI), and was stirred at $T^{\circ} \mathrm{C}\left(0,-50\right.$, or $\left.-70^{\circ} \mathrm{C}\right)$. To the solution, $0.85 \mathrm{~mL}$ of sec-BuLi $(0.44 \mathrm{M}$ in hexane and cyclohexane, $1.5 \mathrm{eq})$ was added rapidly. After $t$ seconds ( $10 \mathrm{or} 60 \mathrm{sec}), 100 \mu \mathrm{L}$ of methanol $(10 \mathrm{eq})$ was added at same temperature, and then the mixture was allowed to be warmed to room temperature. After stirring at room temperature for 30 minutes, and the reaction mixture was then treated with $1 \mathrm{~mL}$ of $1 \mathrm{~N} \mathrm{HCl}$ and $1 \mathrm{~mL}$ of pinacol solution $\left(0.8 \mathrm{M}^{2} \mathrm{Et}_{2} \mathrm{O}\right)$. After addition of EtOAc $(2 \mathrm{~mL})$, brine $(2 \mathrm{~mL})$, $n$-tetradecane (internal standard), the organic phase was analyzed by GC to determine the yields of 2 . The result is summarized in Table S-1.

Table $\mathbf{S}$-1. Synthesis of phenylboronic acid pinacol ester (5) from 1,4-dibromobenzene (3a) using a batch system

\begin{tabular}{ccc}
$T^{\circ} \mathrm{C}$ & $t=10(\mathrm{sec})$ & $t=60 \mathrm{sec}$ \\
\hline 0 & 16 & 20 \\
-50 & 23 & 29 \\
-70 & 33 & 30
\end{tabular}

\section{4-2. Halogen-Lithium Exchange Reaction of Lithium Arylboron-ate Complex 4 Followed by the Reaction with} Methanol in the Flow Microreactor System

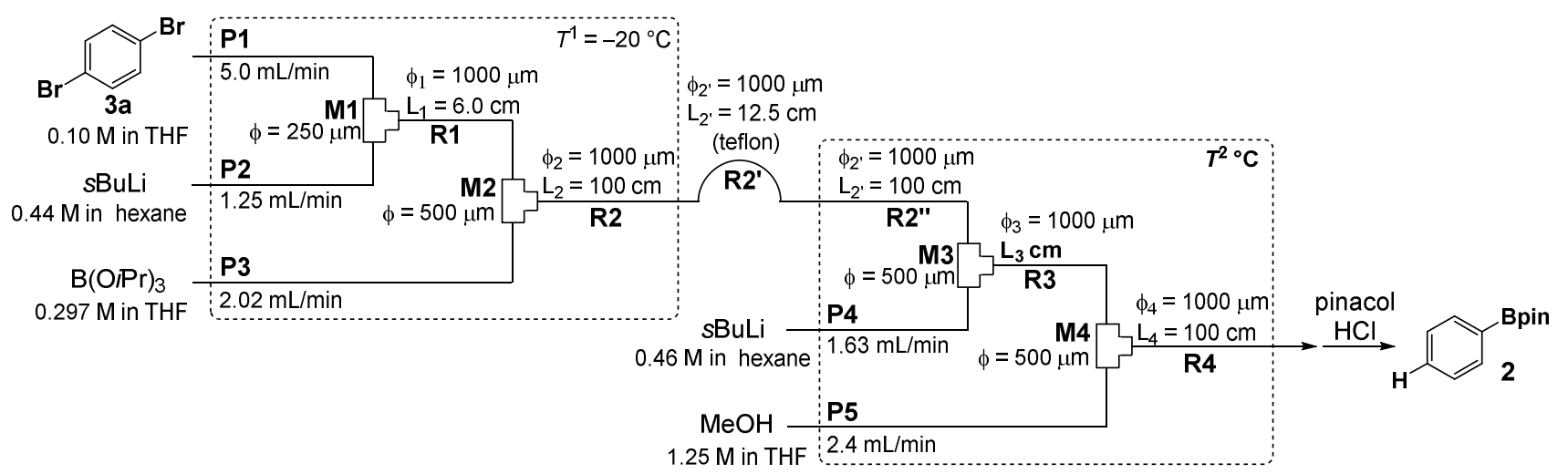

An integrated flow microreactor system consisting of four T-shaped micromixers (M1, M2, M3 and M4), microtube reactors (R1, R2, R2", R3, and R4), and five pre-cooling units (P1 $(100 \mathrm{~cm}), \mathbf{P} 2(50 \mathrm{~cm}), \mathbf{P 3}(50 \mathrm{~cm}), \mathbf{P 4}(50 \mathrm{~cm})$, and P5 (100 cm)) was used. The part of the flow microreactor system composed with P1, P2, P3, M1, M2, R1, and R2 was cooled at $-20{ }^{\circ} \mathrm{C}$ and the part composed with P4, P5, M3, M4, R2", R3, and R4 was cooled at $T^{2}{ }^{\circ} \mathrm{C}$. The reactors in different cooling baths were connected by a PTFE tube R2' $(12.5 \mathrm{~cm})$. A solution of 1,4-dibromobenzene (3a, $0.10 \mathrm{M}$ in THF, flow rate: $5.0 \mathrm{~mL} / \mathrm{min}) \mathrm{and}$ a solution of sec-BuLi (0.44 M in hexane, flow rate: $1.25 \mathrm{~mL} / \mathrm{min})$ were introduced into $\mathbf{M 1}(\phi=250 \mu \mathrm{m})$ by syringe pumps, and the mixture was passed through $\mathbf{R} 1\left(6 \mathrm{~cm}, t^{\mathrm{R} 1}=0.45 \mathrm{~s}\right)$. The solution of monolithiated arenes (flow rate: $\left.6.25 \mathrm{~mL} / \mathrm{min}\right)$ and a solution of B $(\mathrm{O} i \mathrm{Pr})_{3}$ $(0.297 \mathrm{M}$ in THF, flow rate: $2.02 \mathrm{~mL} / \mathrm{min})$ were introduced to $\mathbf{M} 2(\phi=500 \mu \mathrm{m})$, and the mixture was passed through $\mathbf{R} 2(100 \mathrm{~cm}$, $t^{\mathrm{R} 2}=5.7 \mathrm{~s}$ ). The solution of boron-ate complex (flow rate: $8.27 \mathrm{~mL} / \mathrm{min}$ ) was passed through R2' $\left(12.5 \mathrm{~cm}, t^{\mathrm{R} 2^{\prime}}=0.71 \mathrm{~s}\right)$ and $\mathbf{R 2}{ }^{\prime \prime}$ $\left(100 \mathrm{~cm}, t^{\mathrm{R} 2 "}=5.7 \mathrm{~s}\right)$. Then, the solution of boron-ate complex and a solution of sec-BuLi $(0.46 \mathrm{M}$ in hexane, flow rate: 1.63 
$\mathrm{mL} / \mathrm{min})$ were mixed in $\mathbf{M 3}(\phi=500 \mu \mathrm{m})$, and the mixture was passed through $\mathbf{R 3}\left(\mathrm{L}_{3} \mathrm{~cm}\right)$. The resulting solution was introduced to $\mathrm{M} 4(\phi=500 \mu \mathrm{m})$ where a solution of $\mathrm{MeOH}(1.25 \mathrm{M}$ in THF, flow rate: $2.4 \mathrm{~mL} / \mathrm{min})$ was introduced, and the mixture was passed through $\mathbf{R 4}\left(100 \mathrm{~cm}, t^{\mathrm{R} 4}=3.8 \mathrm{~s}\right)$. After a steady state was reached, an aliquot of the product solution was collected for 30 seconds. The aliquot was treated with $1 \mathrm{ml}$ of $1 \mathrm{~N} \mathrm{HCl}$ aq. and $0.8 \mathrm{ml}$ of pinacol solution $\left(0.3 \mathrm{M}\right.$ in $\left.\mathrm{Et}_{2} \mathrm{O}\right)$, and the mixture was stirred at r.t. for $30 \mathrm{~min}$ to be converted to phenylboronic acid pinacol ester (2). After addition of EtOAc ( $2 \mathrm{~mL})$, brine (2 mL), and $n$-tetradecane, the organic phase was analyzed by GC to determine the yields of $\mathbf{5}$. The result is summarized in Table S-2.

Table S-2. Synthesis of phenylboronic acid pinacol ester (5) from 1,4-dibromobenzene (3a) using the integrated flow microreactor system

\begin{tabular}{|c|c|c|c|c|c|c|c|}
\hline$T^{2}\left({ }^{\circ} \mathrm{C}\right)$ & $\mathrm{L}_{3}(\mathrm{~cm})$ & $t^{\mathrm{R} 3}(\mathrm{~s})$ & Yield of 5 (\%) & $T^{2}\left({ }^{\circ} \mathrm{C}\right)$ & $\mathrm{L}_{3}(\mathrm{~cm})$ & $t^{\mathrm{R} 3}(\mathrm{~s})$ & Yield of $5(\%)$ \\
\hline \multirow[t]{6}{*}{0} & 3 & 0.14 & 24 & -50 & 3 & 0.14 & 27 \\
\hline & 6 & 0.29 & 42 & & 6 & 0.29 & 44 \\
\hline & 25 & 1.19 & 23 & & 25 & 1.19 & 67 \\
\hline & 50 & 2.38 & 16 & & 50 & 2.38 & 66 \\
\hline & 100 & 4.76 & 6 & & 100 & 4.76 & 64 \\
\hline & 200 & 9.52 & 2 & & 200 & 9.52 & 60 \\
\hline \multirow[t]{6}{*}{-20} & 3 & 0.14 & 37 & -70 & 3 & 0.14 & 24 \\
\hline & 6 & 0.29 & 49 & & 6 & 0.29 & 40 \\
\hline & 25 & 1.19 & 59 & & 25 & 1.19 & 71 \\
\hline & 50 & 2.38 & 57 & & 50 & 2.38 & 70 \\
\hline & 100 & 4.76 & 15 & & 100 & 4.76 & 71 \\
\hline & 200 & 9.52 & 6 & & 200 & 9.52 & 72 \\
\hline
\end{tabular}

\section{4-3. Halogen-Lithium Exchange Reaction of Lithium Arylboron-ate Complex 4 Followed by the Reaction with} Electrophiles in the Flow Microreactor System

Typical Procedure for the Reaction of Borylated Aryllithiums with Electrophiles.

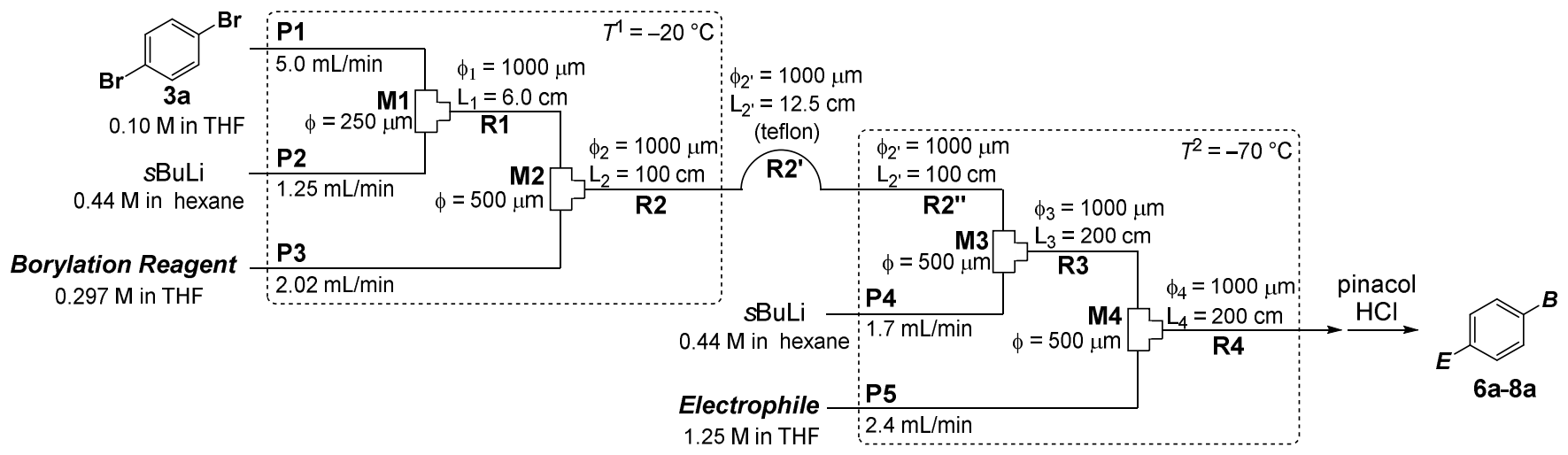

An integrated flow microreactor system consisting of four T-shaped micromixers (M1, M2, M3 and M4), microtube reactors (R1, R2, R2", R3, and R4), and five pre-cooling units (P1 (100 cm), P2 (50 cm), P3 (50 cm), P4 (50 cm), and P5 (100 cm)) was used. The part of the flow microreactor system composed with P1, P2, P3, M1, M2, R1, and R2 was cooled at $-20{ }^{\circ} \mathrm{C}$ and the part composed with P4, P5, M3, M4, R2", R3, and R4 was cooled at $-70{ }^{\circ} \mathrm{C}$. A solution of dibromoarene 3 (0.10 M in THF, flow rate: $5.0 \mathrm{~mL} / \mathrm{min})$ and a solution of $\mathrm{sec}-\mathrm{BuLi}(0.44 \mathrm{M}$ in hexane, flow rate: $1.25 \mathrm{~mL} / \mathrm{min})$ were introduced into $\mathbf{M 1}(\phi=250 \mu \mathrm{m})$ by syringe pumps, and the mixture was passed through $\mathbf{R} 1\left(6 \mathrm{~cm},-20^{\circ} \mathrm{C}, t^{\mathrm{R} 1}=0.45 \mathrm{~s}\right)$. The solution of monolithiated aryls (flow rate: $6.25 \mathrm{~mL} / \mathrm{min})$ and a solution of borylation reagent $\left(\mathrm{B}(\mathrm{O} i \mathrm{Pr})_{3}\right.$ or $\mathrm{B}(\mathrm{O} i \operatorname{Pr})$ pin, $0.297 \mathrm{M}$ in $\mathrm{THF}$, flow rate: $\left.2.02 \mathrm{~mL} / \mathrm{min}\right) \mathrm{were}$ 
introduced to $\mathbf{M} 2(\phi=500 \mu \mathrm{m})$, and the mixture was passed through $\mathbf{R} 2\left(100 \mathrm{~cm},-20{ }^{\circ} \mathrm{C}, t^{\mathrm{R} 2}=5.7 \mathrm{~s}\right)$. The solution of boron-ate complex (flow rate: $8.27 \mathrm{~mL} / \mathrm{min})$ was passed through $\mathbf{R 2}$ ' $\left(12.5 \mathrm{~cm}, t^{\mathrm{R} 2}=0.71 \mathrm{~s}\right)$ and $\mathbf{R 2}$ " $\left(100 \mathrm{~cm}, t^{\mathrm{R} 2}=5.7 \mathrm{~s}\right)$, and was cooled to $-70^{\circ} \mathrm{C}$. Then, the solution of boron-ate complex and a solution of sec-BuLi $(0.44 \mathrm{M}$ in hexane, flow rate: $1.7 \mathrm{~mL} / \mathrm{min}) \mathrm{were}$ mixed in M3 $(\phi=500 \mu \mathrm{m})$, and the mixture was passed through $\mathbf{R 3}(200 \mathrm{~cm})$. The resulting solution was introduced to M4 $(\phi=$ $500 \mu \mathrm{m})$ where a solution of electrophile $(0.675 \mathrm{M}$ in THF, flow rate: $2.4 \mathrm{~mL} / \mathrm{min})$ was added, and the mixture was passed through R4 (200 cm). After a steady state was reached (typically 90 seconds), an aliquot of the product solution was collected for 30 seconds, or the solution was collected in a flame-dried round-bottomed-flask. The aliquot derived from $\mathrm{B}(\mathrm{O} i \mathrm{Pr})_{3}$ was treated with $1 \mathrm{ml}$ of 1 $\mathrm{N} \mathrm{HCl}$ aq. and $1 \mathrm{ml}$ of pinacol solution $\left(0.3 \mathrm{M}\right.$ in $\left.\mathrm{Et}_{2} \mathrm{O}\right)$, and the mixture was stirred at r.t. for 30 min to converted a triisopropoxy borate moiety to a pinacolboranyl group, whereas the aliquot derived from 2-isopropoxy-4,4,5,5-tetramethyl-1,3,2-dioxaborolane $\left(\mathrm{B}(\mathrm{O} i \mathrm{Pr})\right.$ pin) was treated with $\mathrm{NH}_{4} \mathrm{Cl}$ aq. After addition of EtOAc $(2 \mathrm{~mL})$ and brine $(2 \mathrm{~mL}), n$-tetradecane was added, and the organic phase was analyzed by GC to determine the yields of products, and was purified by flash chromatography.<smiles>CC1(C)OB(c2ccc(Cl)cc2)OC1(C)C</smiles><smiles>CC1(C)OB(c2ccc(I)cc2)OC1(C)C</smiles><smiles>CC1(C)OB(c2ccc(C(O)c3ccccc3)cc2)OC1(C)C</smiles>

4-Chlorophenylboronic acid pinacol ester (6a). The reaction solution derived from 1,4dibromobenzene (3a), triisopropyl borate, and hexachloroethane was collected for 30 seconds. The aliquot was analyzed by GC after working-up, and the yield was indicated as $78 \%$. The GC peak was identical with that of the commercial one.

4-Iodophenylboronic acid pinacol ester (7a). The reaction solution derived from 1,4dibromobenzene (3a), triisopropyl borate, and iodine was collected for 30 seconds. The aliquot was analyzed by GC after working-up, and the yield was indicated as 93\%. The GC peak was identical with that of the commercial one.

4-(4,4,5,5-Tetramethyl-1,3,2-dioxaborolan-2-yl)benzhydrol (8a). The reaction solution derived from 1,4-dibromobenzene (3a), 2-isopropoxy-4,4,5,5-tetramethyl-1,3,2-dioxaborolane, and benzaldehyde was collected for 30 seconds. The aliquot was analyzed by GC after workingup, and the yield was indicated as $80 \% ;{ }^{1} \mathrm{H}$ NMR (400 MHz, $\left.\mathrm{CDCl}_{3}\right) \delta 1,32(\mathrm{~s}, 12 \mathrm{H}), 5.82$ (s, $1 \mathrm{H}), 7.22-7.26(\mathrm{~m}, 1 \mathrm{H}), 7.29-7.39(\mathrm{~m}, 6 \mathrm{H}), 7.78(\mathrm{~d}, J=8.4 \mathrm{~Hz}, 2 \mathrm{H}) ;{ }^{13} \mathrm{C} \mathrm{NMR}(100 \mathrm{MHz}$, $\left.\mathrm{CDCl}_{3}\right) \delta 24.8,76.1,83.7,125.7,126.5,127.5,128.4,134.9,143.6,146.8$ (one carbon attached to $\mathrm{B}$ atom is not visible); HRMS (ESI) calcd for $\mathrm{C}_{19} \mathrm{H}_{23} \mathrm{BO}_{3} \mathrm{Na}\left[\mathrm{M}+\mathrm{Na}^{+}\right]$: 333.1632 , found 333.1635 .

\section{4-4. Halogen-Lithium Exchange Reaction of Lithium Arylboron-ate Complex 4 Followed by the Reaction with} Metalation Reagents in the Flow Microreactor System. Typical Procedure for Synthesizing Bi-Metallic Arenes.

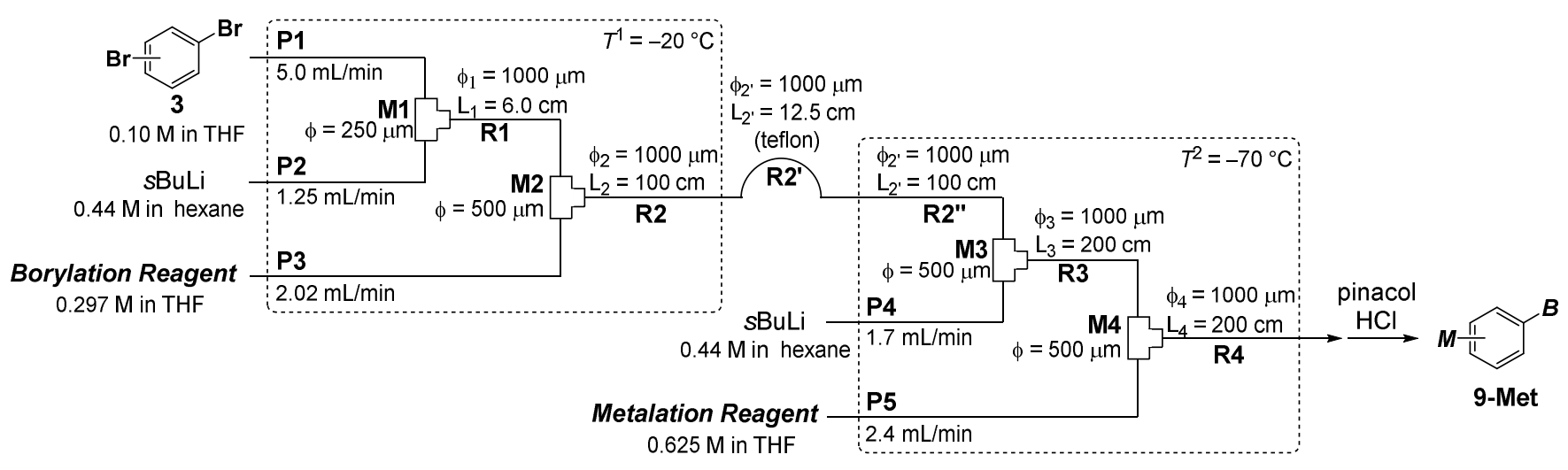


An integrated flow microreactor system consisting of four T-shaped micromixers (M1, M2, M3 and M4), microtube reactors (R1, R2, R2", R3, and R4), and five pre-cooling units (P1 $(100 \mathrm{~cm}), \mathbf{P 2}(50 \mathrm{~cm}), \mathbf{P 3}(50 \mathrm{~cm}), \mathbf{P 4}(50 \mathrm{~cm})$, and P5 (100 cm)) was used. The part of the flow microreactor system composed with P1, P2, P3, M1, M2, R1, and R2 was cooled at $-20{ }^{\circ} \mathrm{C}$ and the part composed with P4, P5, M3, M4, R2", R3, and R4 was cooled at $-70{ }^{\circ} \mathrm{C}$. A solution of dibromoarenes 3 (0.10 M in THF, flow rate: $5.0 \mathrm{~mL} / \mathrm{min})$ and a solution of $\sec -\operatorname{BuLi}(0.44 \mathrm{M}$ in hexane, flow rate: $1.25 \mathrm{~mL} / \mathrm{min})$ were introduced into $\mathbf{M 1}(\phi=250 \mu \mathrm{m})$ by syringe pumps, and the mixture was passed through $\mathbf{R} 1\left(6 \mathrm{~cm},-20^{\circ} \mathrm{C}, t^{\mathrm{R} 1}=0.45 \mathrm{~s}\right)$. The solution of monolithiated arenes (flow rate: $6.25 \mathrm{~mL} / \mathrm{min})$ and a solution of borylation reagent $\left(\mathrm{B}(\mathrm{O} i \mathrm{Pr})_{3}\right.$ or $\mathrm{B}(\mathrm{O} i \operatorname{Pr})$ pin, $0.297 \mathrm{M}$ in $\mathrm{THF}$, flow rate: $\left.2.02 \mathrm{~mL} / \mathrm{min}\right) \mathrm{were}$ introduced to $\mathbf{M} 2(\phi=500 \mu \mathrm{m})$, and the mixture was passed through $\mathbf{R 2}\left(100 \mathrm{~cm},-20{ }^{\circ} \mathrm{C}, t^{\mathrm{R} 2}=5.7 \mathrm{~s}\right)$. The solution of boron-ate complex (flow rate: $8.27 \mathrm{~mL} / \mathrm{min})$ was passed through $\mathbf{R 2}$ ' $\left(12.5 \mathrm{~cm}, t^{\mathrm{R} 2}=0.71 \mathrm{~s}\right)$ and $\mathbf{R 2}$ " $\left(100 \mathrm{~cm}, t^{\mathrm{R} 2}\right.$ " $\left.=5.7 \mathrm{~s}\right)$, and was cooled to $-70{ }^{\circ} \mathrm{C}$. Then, the solution of boron-ate complex and a solution of $\mathrm{sec}$-BuLi (0.46 $\mathrm{M}$ in hexane, flow rate: $\left.1.63 \mathrm{~mL} / \mathrm{min}\right) \mathrm{were}$ mixed in $\mathbf{M 3}(\phi=500 \mu \mathrm{m})$, and the mixture was passed through $\mathbf{R 3}(200 \mathrm{~cm})$. The resulting solution of $\mathbf{5 a - L i}$ was introduced to M4 $(\phi=500 \mu \mathrm{m})$ where a solution of metalation reagent $(0.625 \mathrm{M}$ in THF, flow rate: $2.4 \mathrm{~mL} / \mathrm{min})$ was added, and the mixture was passed through R4 (200 cm). After a steady state was reached (typically 90 seconds), an aliquot of the product solution was collected for 30 seconds, or the solution was collected in a flame-dried round-bottomed-flask. The aliquot derived from $\mathrm{B}(\mathrm{O} i \mathrm{Pr})_{3}$ was treated with $1 \mathrm{ml}$ of $1 \mathrm{~N} \mathrm{HCl}$ aq. and $1 \mathrm{ml}$ of pinacol solution $\left(0.3 \mathrm{M}\right.$ in $\left.\mathrm{Et}_{2} \mathrm{O}\right)$, and the mixture was stirred at r.t. for 30 min to converted triisopropoxy borate moiety to pinacolboranyl group, whereas the aliquot derived from $\mathrm{B}(\mathrm{O} i \mathrm{Pr})$ pin was treated with $\mathrm{NH}_{4} \mathrm{Cl}$ aq. $\mathrm{After}$ addition of EtOAc $(2 \mathrm{~mL})$ and brine $(2 \mathrm{~mL}), n$-tetradecane was added, and the organic phase was analyzed by GC to determine the yields of product 9-Met, and was purified by flash chromatography.
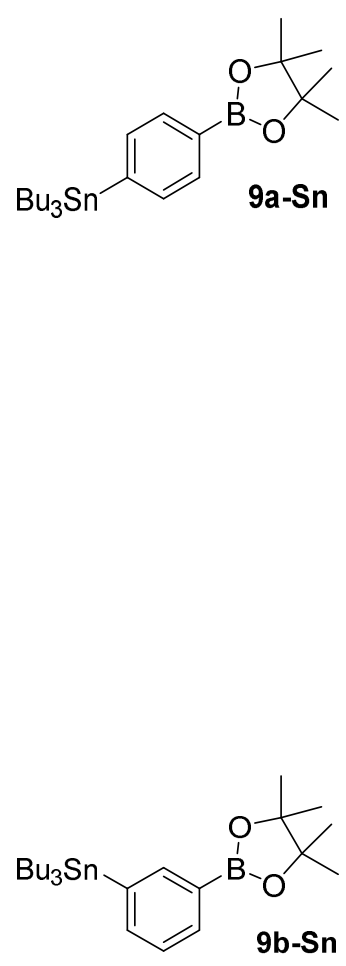

4-Tri-n-butylstannylphenylboronic acid pinacol ester (9a-Sn, Table 1, entry 1-3. For entry $\left.1, \mathrm{~L}_{1}=12.5 \mathrm{~cm}, t^{\mathrm{R} 1}=0.93 \mathrm{~s}\right)$. The reaction solution was obtained from the reaction of $1,4-$ dibromobenzene (3a), triisopropyl borate, and tri- $n$-butylstannyl chloride, and collected in a $100 \mathrm{~mL}$ round-bottomed flask. The aliquot $(3 \mathrm{~mL})$ was analyzed by $\mathrm{GC}$ after working-up, and the yield was indicated as $77 \%$, or the aliquot $(6 \mathrm{~mL})$ was purified by flash chromatography using 1-3\% EtOAc/hexane as an eluent to obtain the title compound in $75 \%$ yield $(89.8 \mathrm{mg}$, $0.182 \mathrm{mmol}$ ); Colorless oil. TLC $\mathrm{R}_{f} 0.18$ (hexane/EtOAc 50:1): ${ }^{1} \mathrm{H}$ NMR (400 MHz, $\left.\mathrm{CDCl}_{3}\right) \delta$ $0.87(\mathrm{t}, J=7.2 \mathrm{~Hz}, 9 \mathrm{H}), 1.05$ (dd, $J=8.0,8.0 \mathrm{~Hz}, 6 \mathrm{H}), 1.27-1.36$ (m, $6 \mathrm{H}), 1.34$ (s, $12 \mathrm{H})$, 1.49-1.57 (m, $6 \mathrm{H}), 7.48(\mathrm{~d}, J=6.8 \mathrm{~Hz}, 2 \mathrm{H}), 7.74(\mathrm{~d}, J=6.8 \mathrm{~Hz}, 2 \mathrm{H}) ;{ }^{13} \mathrm{C} \mathrm{NMR}(100 \mathrm{MHz}$, $\mathrm{CDCl}_{3}$ ) $\delta 9.5,13.7,24.8,27.4,29.1,83.7,133.8,135.9,146.5$ (one carbon attached to $\mathrm{B}$ atom is not visible); HRMS (ESI) calcd for $\mathrm{C}_{24} \mathrm{H}_{43} \mathrm{BO}_{2} \mathrm{SnNa}\left[\mathrm{M}+\mathrm{Na}^{+}\right]$: 517.2270, found 517.2276.

3-Tri-n-butylstannylphenylboronic acid pinacol ester (9b-Sn, Table 1, entry 4 and 5). The reaction solution derived from 1,3-dibromobenzene (3b), triisopropyl borate, and tri- $n$ butylstannyl chloride was collected for 30 seconds. The aliquot was analyzed by GC after working-up, and the yield was indicated as 69\%; Colorless oil. TLC $\mathrm{R}_{f} 0.19$ (hexane/EtOAc 50:1): ${ }^{1} \mathrm{H}$ NMR (400 MHz, $\left.\mathrm{CDCl}_{3}\right) \delta 0.88(\mathrm{t}, J=7.2 \mathrm{~Hz}, 9 \mathrm{H}), 1.06(\mathrm{dd}, J=8.0,8.0 \mathrm{~Hz}, 6 \mathrm{H})$, 1.34 (s, 12 H), 1.28-1.37 (m, 6 H), 1.49-1.59 (m, 6 H), 7.32 (dt, J=0.8, 7.6 Hz, 1 H), 7.55 (dt, $J=1.2,7.2 \mathrm{~Hz}, 1 \mathrm{H}), 7.74(\mathrm{dt}, J=1.2,7.2 \mathrm{~Hz}, 1 \mathrm{H}), 7.88(\mathrm{~s}, 1 \mathrm{H}) ;{ }^{13} \mathrm{C} \mathrm{NMR}\left(100 \mathrm{MHz}, \mathrm{CDCl}_{3}\right)$ $\delta 9.5,13.7,24.9,27.4,29.1,83.6,127.2,134.4,139.4,141.1,142.8$ (one carbon attached to B atom is not visible); HRMS (ESI) calcd for $\mathrm{C}_{24} \mathrm{H}_{43} \mathrm{BO}_{2} \mathrm{SnNa}\left[\mathrm{M}+\mathrm{Na}^{+}\right]$: 517.2270, found 517.2271. 
<smiles>CC(C)(C)[SnH2]c1cc(Br)cc(B2OC(C)(C)C(C)(C)O2)c1</smiles><smiles>CCCCc1cc(B2OC(C)(C)C(C)(C)O2)cc(C(=O)OC(C)(C)C)c1</smiles>

3-Bromo-5-tri-n-butylstannylphenylboronic acid pinacol ester (9c-Sn, Table 1, entry 6). The reaction solution derived from 1,3,5-tribromobenzene (3c), triisopropyl borate, and tri- $n$ butylstannyl chloride was collected for 30 seconds. The aliquot was analyzed by GC after working-up, and the yield was indicated as 92\%; TLC $\mathrm{R}_{f} 0.59$ (hexane/EtOAc 50:1): ${ }^{1} \mathrm{H}$ NMR $\left(400 \mathrm{MHz}, \mathrm{CDCl}_{3}\right) \delta 0.89(\mathrm{t}, J=7.6 \mathrm{~Hz}, 9 \mathrm{H}), 1.07(\mathrm{dd}, J=8.0,8.0 \mathrm{~Hz}, 6 \mathrm{H}), 1.28-1.37(\mathrm{~m}, 6$ H), $1.34(\mathrm{~s}, 12 \mathrm{H}), 1.43-1.61(\mathrm{~m}, 6 \mathrm{H}), 7.63$ (d, $J=0.8,2.0 \mathrm{~Hz}, 1 \mathrm{H}), 7.76(\mathrm{dd}, J=0.8,0.8 \mathrm{~Hz}$, $1 \mathrm{H}), 7.85(\mathrm{dd}, J=0.8,2.0 \mathrm{~Hz}, 1 \mathrm{H}) ;{ }^{13} \mathrm{C} \mathrm{NMR}\left(100 \mathrm{MHz}, \mathrm{CDCl}_{3}\right) \delta$ 9.7, 13.7, 24.8, 27.3, 29.0, 84.0, 123.2, 136.9, 140.8, 141.3, 144.5 (one carbon attached to B atom is not visible); HRMS (ESI) calcd for $\mathrm{C}_{24} \mathrm{H}_{42} \mathrm{BBrO}_{2} \mathrm{SnNa}\left[\mathrm{M}+\mathrm{Na}^{+}\right]$: 595.1375, found 595.1370.

3-tert-Butoxycarbonyl-5-tri-n-butylstannylphenylboronic acid pinacol ester (9d-Sn, Table 1, entry 7). The reaction solution derived from tert-butyl 3,5-dibromobenzoate (3d), triisopropyl borate, and tri- $n$-butylstannyl chloride was collected for 30 seconds. The aliquot was analyzed by GC after working-up, and the yield was indicated as $80 \%$; Colorless oil. TLC $\mathrm{R}_{f} 0.47$ (hexane/EtOAc 10:1): ${ }^{1} \mathrm{H}$ NMR $\left(400 \mathrm{MHz}, \mathrm{CDCl}_{3}\right) \delta 0.90(\mathrm{t}, J=7.6 \mathrm{~Hz}, 9 \mathrm{H}), 1.11(\mathrm{dd}, J=$ 8.0, 8.0 Hz, 6 H), 1.34-1.39 (m, 18 H), 1.52-1.60 (m, 6 H), 1.61 (s, 9 H), 8.04 (dd, J = 1.2, 2.0 $\mathrm{Hz}, 1 \mathrm{H}), 8.20-8.21(\mathrm{~m}, 1 \mathrm{H}), 8.32-8.34(\mathrm{~m}, 1 \mathrm{H}) ;{ }^{13} \mathrm{C} \mathrm{NMR}\left(100 \mathrm{MHz}, \mathrm{CDCl}_{3}\right) \delta$ 9.8, 13.9, 25.1, 27.6, 28.4, 29.3, 80.9, 84.1, 130.7, 135.5, 140.2, 141.5, 147.0, 166.6 (one carbon attached to $\mathrm{B}$ atom is not visible); HRMS (ESI) calcd for $\mathrm{C}_{29} \mathrm{H}_{51} \mathrm{BO}_{4} \mathrm{SnNa}\left[\mathrm{M}+\mathrm{Na}^{+}\right]$: 617.2795 , found 617.2783 .

5-Tri-n-butylstannyl-2-thiopheneboronic acid pinacol ester (9e-Sn, Table 1, entry 8). The reaction solution derived from 2,5-dibromothiophene (3e), triisopropyl borate, and tri- $n$ butylstannyl chloride was collected for 30 seconds. The aliquot was analyzed by GC after working-up, and the yield was indicated as 58\%; Colorless oil. TLC $\mathrm{R}_{f} 0.20$ (hexane/EtOAc 10:1): ${ }^{1} \mathrm{H}$ NMR (400 MHz, $\left.\mathrm{CDCl}_{3}\right) \delta 0.89$ (t, $\left.J=7.2 \mathrm{~Hz}, 9 \mathrm{H}\right), 1.09-1.13(\mathrm{~m}, 6 \mathrm{H}), 1.28-1.37$ (m, $6 \mathrm{H}), 1.35(\mathrm{~s}, 12 \mathrm{H}), 1.46-1.68(\mathrm{~m}, 6 \mathrm{H}), 7.28(\mathrm{~d}, J=3.2 \mathrm{~Hz}, 1 \mathrm{H}), 7.78(\mathrm{~d}, J=3.2 \mathrm{~Hz}, 1$ $\mathrm{H}) ;{ }^{13} \mathrm{C}$ NMR $\left(100 \mathrm{MHz}, \mathrm{CDCl}_{3}\right) \delta 10.8,13.6,24.7,27.2,28.9,83.9,136.3,137.6,145.5$ (one carbon attached to $\mathrm{B}$ atom is not visible); HRMS (ESI) calcd for $\mathrm{C}_{22} \mathrm{H}_{41} \mathrm{BO}_{2} \mathrm{SSnNa}\left[\mathrm{M}+\mathrm{Na}^{+}\right]$: 523.1834, found 523.1822 .

2-Tri-n-butylstannylpyridin-3-boronic acid pinacol ester (9f-Sn, Table 1, entry 9). The reaction $\left(\mathrm{L}_{2}=200 \mathrm{~cm}, 3.0\right.$ eq. of second $\left.s \mathrm{BuLi}\right)$ was performed with 2,3-dibromopyridine (3f), 2-isopropoxy-4,4,5,5-tetramethyl-1,3,2-dioxaborolane, and tri- $n$-butylstannyl chloride (5.0 eq). The aliquot collected in 30 seconds was analyzed by GC after working-up, and the yield was indicated as 51\%; Pale yellow oil. TLC $\mathrm{R}_{f} 0.85\left(\mathrm{CHCl}_{3} / \mathrm{MeOH} 10: 1\right):{ }^{1} \mathrm{H}$ NMR (400 MHz, $\left.\mathrm{CDCl}_{3}\right) \delta 0.86(\mathrm{t}, J=7.6 \mathrm{~Hz}, 9 \mathrm{H}), 1.13(\mathrm{dd}, J=8.0,8.0 \mathrm{~Hz}, 6 \mathrm{H}), 1.31$ (sextet, $J=7.6 \mathrm{~Hz}, 6$ H), 1.35 (s, 12 H), 1.49-1.59 (m, 6 H), 7.10 (dd, $J=5.2,7.6 \mathrm{~Hz}, 1 \mathrm{H}), 7.99$ (dd, $J=2.0,7.6 \mathrm{~Hz}$, $1 \mathrm{H}), 8.75(\mathrm{dd}, J=2.0,5.2 \mathrm{~Hz}, 1 \mathrm{H}) ;{ }^{13} \mathrm{C} \mathrm{NMR}\left(100 \mathrm{MHz}, \mathrm{CDCl}_{3}\right) \delta 11.5,13.8,24.8,27.5,29.2$, $84.1,120.9,140.9,151.4,182.1$ (one carbon attached to B atom is not visible); HRMS (ESI) calcd for $\mathrm{C}_{23} \mathrm{H}_{42} \mathrm{BNO}_{2} \mathrm{SnNa}\left[\mathrm{M}+\mathrm{Na}^{+}\right]$: 518.2223, found 518.2221. 


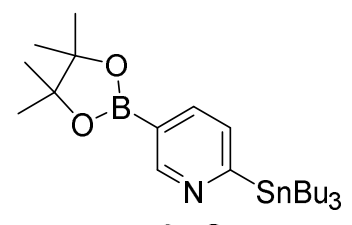

9g-Sn

2-Tri-n-butylstannylpyridin-5-boronic acid pinacol ester (9g-Sn, Table 1, entry 10). The reaction $\left(\mathrm{L}_{2}=200 \mathrm{~cm}, 3.0\right.$ eq. of second $\left.s \mathrm{BuLi}\right)$ was performed with 2,5-dibromopyridine (3g), 2-isopropoxy-4,4,5,5-tetramethyl-1,3,2-dioxaborolane, and tri- $n$-butylstannyl chloride (5.0 eq). The aliquot collected in 30 seconds was analyzed by GC after working-up, and the yield was indicated as 48\%; Colorless oil. TLC $\mathrm{R}_{f} 0.42\left(\mathrm{CHCl}_{3} / \mathrm{MeOH} 10: 1\right):{ }^{1} \mathrm{H} \mathrm{NMR}\left(400 \mathrm{MHz}, \mathrm{CDCl}_{3}\right)$ $\delta 0.87(\mathrm{t}, J=7.6 \mathrm{~Hz}, 9 \mathrm{H}), 1.12(\mathrm{~m}, 6 \mathrm{H}), 1.27-1.36(\mathrm{~m}, 6 \mathrm{H}), 1.34$ (s, $12 \mathrm{H}), 1.51-1.59(\mathrm{~m}, 6$ H), $7.41(\mathrm{dd}, J=0.8,7.2 \mathrm{~Hz}, 1 \mathrm{H}), 7.84(\mathrm{dd}, J=1.6,7.6 \mathrm{~Hz}, 1 \mathrm{H}), 9.03$ (dd, $J=0.8,1.6 \mathrm{~Hz}, 1$ $\mathrm{H}) ;{ }^{13} \mathrm{C}$ NMR $\left(100 \mathrm{MHz}, \mathrm{CDCl}_{3}\right) \delta 9.8,13.7,24.8,27.3,29.0,84.0,131.8,139.0,155.5,177.7$ (one carbon attached to $\mathrm{B}$ atom is not visible); HRMS (ESI) calcd for $\mathrm{C}_{23} \mathrm{H}_{43} \mathrm{BNO}_{2} \mathrm{SnNa}$ $\left[\mathrm{M}+\mathrm{H}^{+}\right]:$496.2403, found 496.2411.

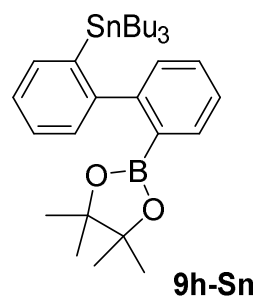

2'-Tri-n-butylstannylbiphenyl-2-boronic acid pinacol ester (9h-Sn, Table 1, entry 11). The reaction solution derived from 2,2'-dibromobiphenyl (3h), 2-isopropoxy-4,4,5,5-tetramethyl1,3,2-dioxaborolane, and tri- $n$-butylstannyl chloride was collected for 30 seconds. The aliquot was analyzed by GC after working-up, and the yield was indicated as 73\%; Colorless oil. TLC $\mathrm{R}_{f} 0.52$ (hexane/EtOAc 10:1): ${ }^{1} \mathrm{H}$ NMR $\left(400 \mathrm{MHz}, \mathrm{CDCl}_{3}\right) \delta 0.67$ (dd, $\left.J=8.0,8.0 \mathrm{~Hz}, 6 \mathrm{H}\right)$, $0.82(\mathrm{t}, J=7.2 \mathrm{~Hz}, 9 \mathrm{H}), 1.08(\mathrm{br}, \mathrm{d}, J=8.0 \mathrm{~Hz}, 12 \mathrm{H}), 1.21(\mathrm{tq}, J=7.2,7.2 \mathrm{~Hz}, 6 \mathrm{H}), 1.27-$ $1.36(\mathrm{~m}, 6 \mathrm{H}), 7.15-7.26(\mathrm{~m}, 4 \mathrm{H}), 7.31(\mathrm{ddd}, J=1.2,7.2,7.2 \mathrm{~Hz}, 1 \mathrm{H}), 7.39(\mathrm{ddd}, J=1.6,7.2$, $7.2 \mathrm{~Hz}, 1 \mathrm{H}), 7.46(\mathrm{dd}, J=1.6,6.8 \mathrm{~Hz}, 1 \mathrm{H}), 7.71(\mathrm{dd}, J=1.6,7.2 \mathrm{~Hz}, 1 \mathrm{H}) ;{ }^{13} \mathrm{C}$ NMR $(100$ $\left.\mathrm{MHz}, \mathrm{CDCl}_{3}\right) \delta 10.2,13.6,24.3$ and 24.7 (rotameric), 27.4, 28.9, 83.2, 125.7, 126.2, 12.6, 129.2, $129.5,129.6,134.2,135.8,141.7,150.9,151.3$ (one carbon attached to B atom is not visible); HRMS (ESI) calcd for $\mathrm{C}_{30} \mathrm{H}_{47} \mathrm{BO}_{2} \mathrm{SnNa}\left[\mathrm{M}+\mathrm{Na}^{+}\right]$: 593.2583, found 593.2573.

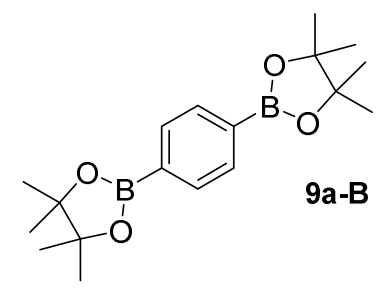

1,4-Benzenediboronic acid bis(pinacol) ester (9a-B, Table 1, entry 12). The reaction solution derived from 1,4-dibromobenzene (3a) and isopropoxyboronic acid pinacol ester (as both borylation and metalation reagent) was collected for 30 seconds. The aliquot was analyzed by GC after working-up, and the yield was indicated as $68 \%$. The GC peak was identical with that of the commercial one.

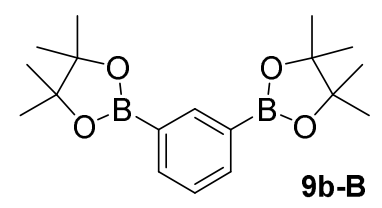

1,3-Benzenediboronic Acid Bis(pinacol) Ester (9b-B, Table 1, entry 13). The reaction solution derived from 1,3-dibromobenzene (3b) and isopropoxyboronic acid pinacol ester (as both borylation and metalation reagent) was collected for 30 seconds. The aliquot was analyzed by GC after working-up, and the yield was indicated as $66 \%$. The GC peak was identical with that of the commercial one.

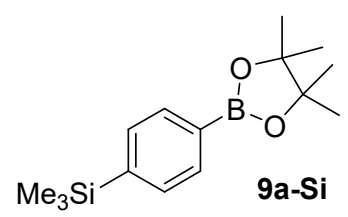

4-Trimethylphenylboronic acid pinacol ester (9a-Si, Table 1, entry 14). The reaction solution derived from 1,4-dibromobenzene (3a), triisopropyl borate, and trimethylsilyl chloride was collected for 30 seconds. The aliquot was analyzed by GC after working-up, and the yield was indicated as 78\%; White solid. TLC $\mathrm{R}_{f} 0.22$ (hexane/EtOAc 10:1): ${ }^{1} \mathrm{H}$ NMR (400 MHz, $\mathrm{CDCl}_{3}$ ) $\delta 0.27$ (s, $9 \mathrm{H}), 1.34$ (s, $12 \mathrm{H}), 7.53$ (d, $J=8.0 \mathrm{~Hz}, 2 \mathrm{H}), 7.79$ (d, $J=8.0 \mathrm{~Hz}, 2 \mathrm{H})$. The NMR spectrum was in a good agreement with the reported one. ${ }^{[3]}$ 


\section{4-5. Flow Synthesis for Zn-B Bimetallic Arenes and their Transformation.}

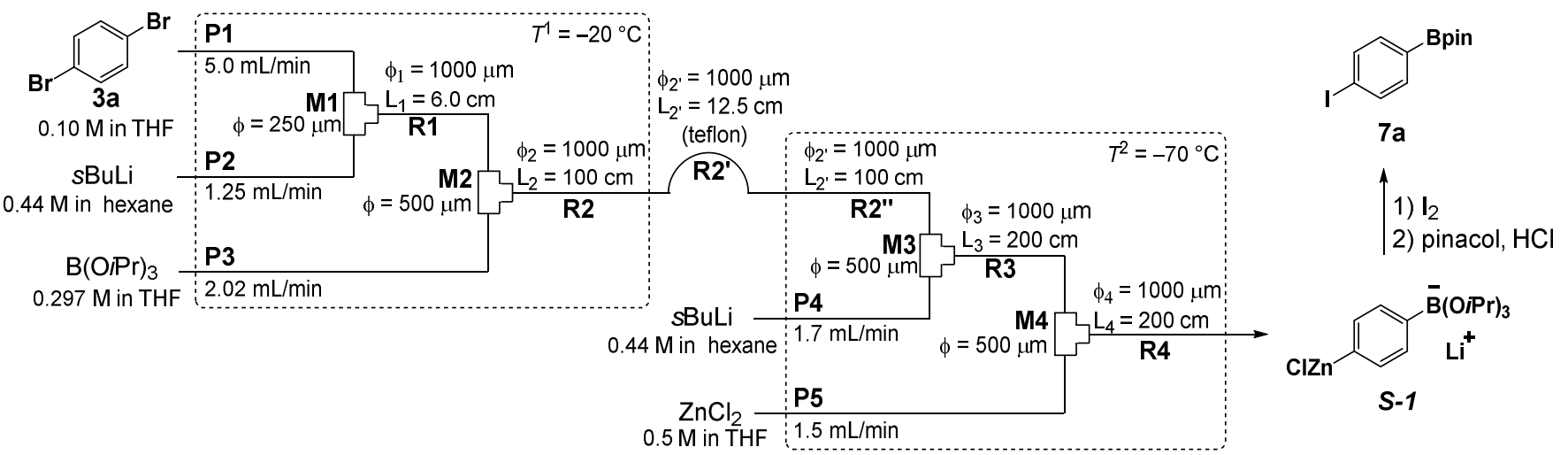

An integrated flow microreactor system consisting of four T-shaped micromixers (M1, M2, M3 and M4), microtube reactors (R1, R2, R2", R3, and R4), and five pre-cooling units (P1 (100 cm), P2 (50 cm), P3 (50 cm), P4 (50 cm), and P5 (100 cm)) was used. The part of the flow microreactor system composed with P1, P2, P3, M1, M2, R1, and R2 was cooled at $-20{ }^{\circ} \mathrm{C}$ and the part composed with P4, P5, M3, M4, R2", R3, and R4 was cooled at $-70^{\circ} \mathrm{C}$. Those two parts were connected by PTFE tube R2' $(12.5 \mathrm{~cm})$. A solution of dibromoarenes $3(0.10 \mathrm{M}$ in THF, flow rate: $5.0 \mathrm{~mL} / \mathrm{min})$ and a solution of $\mathrm{sec}$-BuLi $(0.44 \mathrm{M}$ in hexane, flow rate: $1.25 \mathrm{~mL} / \mathrm{min})$ were introduced into $\mathbf{M 1}(\phi=250 \mu \mathrm{m})$ by syringe pumps, and the mixture was passed through $\mathbf{R} 1(6 \mathrm{~cm}$, $\left.-20{ }^{\circ} \mathrm{C}, t^{\mathrm{R} 1}=0.45 \mathrm{~s}\right)$. The solution of monolithiated aryls (flow rate: $\left.6.25 \mathrm{~mL} / \mathrm{min}\right)$ and a solution of $\mathrm{B}(\mathrm{O} i \operatorname{Pr})_{3}(0.297 \mathrm{M}$ in THF, flow rate: $2.02 \mathrm{~mL} / \mathrm{min})$ were introduced to $\mathbf{M} 2(\phi=500 \mu \mathrm{m})$, and the mixture was passed through $\mathbf{R 2}\left(100 \mathrm{~cm},-20{ }^{\circ} \mathrm{C}, t^{\mathrm{R} 2}=5.7\right.$ s). The solution of boron-ate complex (flow rate: $8.27 \mathrm{~mL} / \mathrm{min})$ was passed through $\mathbf{R 2}^{\prime}\left(12.5 \mathrm{~cm}, t^{\mathrm{R} 2}=0.71 \mathrm{~s}\right)$ and $\mathbf{R 2}$ ” $(100 \mathrm{~cm}$, $\left.t^{\mathrm{R} 2 "}=5.7 \mathrm{~s}\right)$, and was cooled to $-70^{\circ} \mathrm{C}$. Then, the solution of boron-ate complex and a solution of sec-BuLi $(0.44 \mathrm{M}$ in hexane, flow rate: $1.7 \mathrm{~mL} / \mathrm{min})$ were mixed in $\mathbf{M} 3(\phi=500 \mu \mathrm{m})$, and the mixture was passed through $\mathbf{R 3}(200 \mathrm{~cm})$. The resulting solution was introduced to $\mathbf{M} 4(\phi=500 \mu \mathrm{m})$ where a solution of electrophile $(0.5 \mathrm{M}$ in THF, flow rate: $1.5 \mathrm{~mL} / \mathrm{min})$ was added, and the mixture was passed through R4 (200 cm). After a steady state was reached (90 seconds), the solution was collected in a flame-dried roundbottomed-flask as the solution of $\boldsymbol{Z n}-\boldsymbol{B}$ bimetallic arenes. To the aliquot $(3.0 \mathrm{~mL}, 0.131 \mathrm{mmol})$ of the solution, was added iodine (230 mg, $0.91 \mathrm{mmol})$. The mixture was stirred at room temperature for 2 hours, and then was treated with pinacol and $\mathrm{HCl}$. The yield of 7a was determined by GC analysis (68\%).

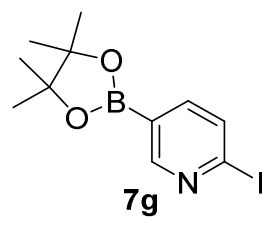

2-Iodopyridyl-5-boronic acid pinacol ester (7g). The reaction was performed with R2 (200 $\mathrm{cm})$ and isopropoxyboronic acid pinacol ester (1.2 eq), followed by the reaction with iodine (300 mg). The mixture was washed with $\mathrm{Na}_{2} \mathrm{~S}_{2} \mathrm{O}_{3}$ aq and the solution was analyzed by GC to determine the yield (56\%); White solid: ${ }^{1} \mathrm{H}$ NMR (400 MHz, $\left.\mathrm{CDCl}_{3}\right) \delta 1.34$ (s, $\left.12 \mathrm{H}\right), 7.65$ (dd, $J=2.0,8.0 \mathrm{~Hz}, 1 \mathrm{H}), 7.74(\mathrm{dd}, J=0.8,8.0 \mathrm{~Hz}, 2 \mathrm{H}), 8.65(\mathrm{dd}, J=0.8,2.0 \mathrm{~Hz}, 1 \mathrm{H}) ;{ }^{13} \mathrm{C} \mathrm{NMR}$ $\left(100 \mathrm{MHz} \mathrm{CDCl}_{3}\right) \delta 24.8,84.5,122.0,134.4,143.3,156.2$ (one carbon attached to $\mathrm{B}$ atom is not visible); HRMS (ESI) calcd for $\mathrm{C}_{11} \mathrm{H}_{16} \mathrm{BINO}_{2}\left[\mathrm{M}+\mathrm{Ha}^{+}\right]$: 332.0313 , found 332.0318 .

\section{4-6. ${ }^{11}$ B NMR analyses of Sn-B Bimetallic Benzene S-2.}

Before working-up, the aliquot $(6.9 \mathrm{~mL})$ of the reaction solution of 9a-Sn (e.g. 0.029 M) was concentrated under reduced pressure. Thus-obtained white solid (lithium triisopropyl 4-tri- $n$-butylstannylphenylborate, $\boldsymbol{S}$-2, approx. $0.2 \mathrm{mmol}$ ) was dissolved in $0.7 \mathrm{~mL}$ of methanol- $d_{4}$, and the solution was analyzed by ${ }^{11} \mathrm{~B}$ NMR, which showed two singlet peaks on 5.2 and $3.2 \mathrm{ppm}$. 


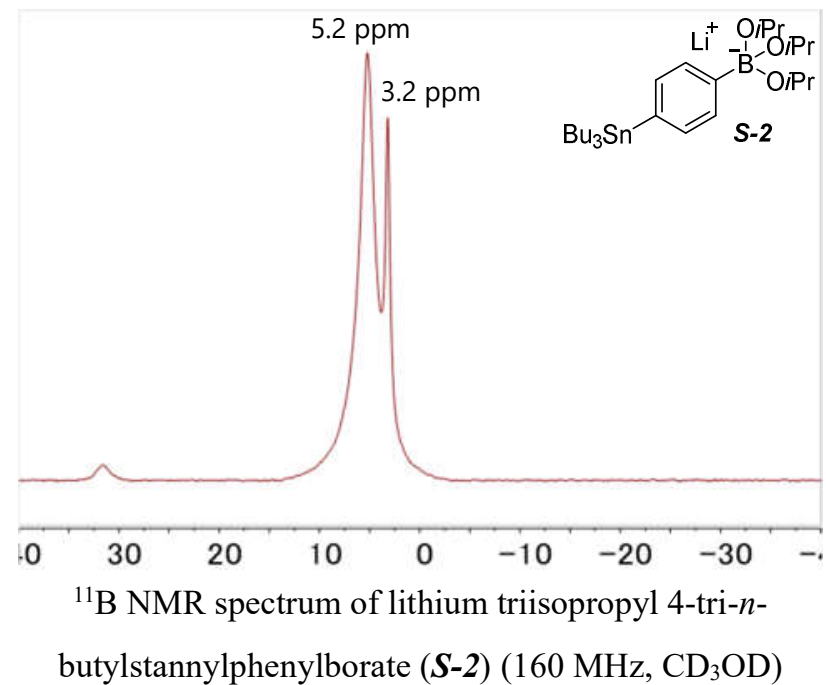

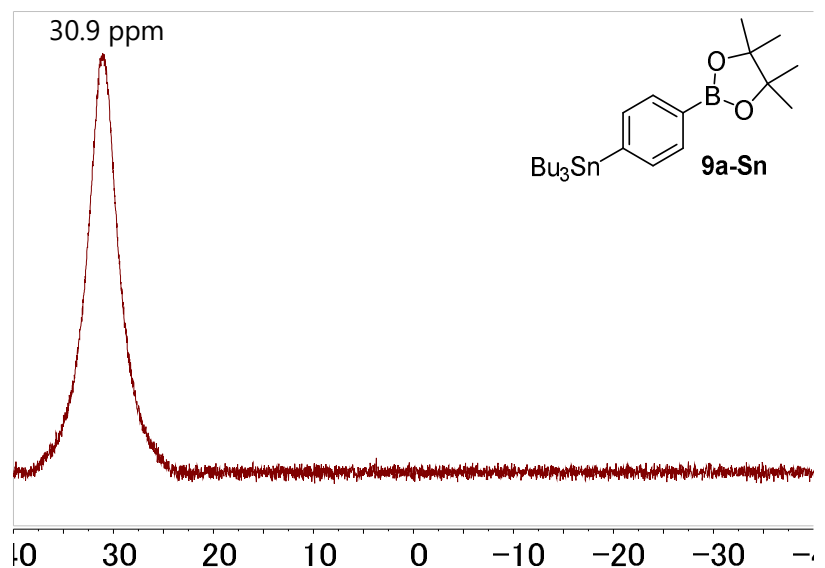

${ }^{11} \mathrm{~B}$ NMR spectrum of 4-tri- $n$-butylstannylphenylboronic acid pinacol ester (9a-Sn) (160 MHz, $\left.\mathrm{CD}_{3} \mathrm{OD}\right)$

\section{Cross Coupling Reactions of Bimetallic Arenes.}

\section{5-1. Optimization of Cross Coupling Reactions of Sn-B Bimetallic Benzene 5a-Sn.}<smiles>CC(C)(C)Oc1ccc(-c2ccc(-c3ccc(C(C)(C)C)cc3)cc2)cc1</smiles>

The aliquot (6.9 mL) of the reaction solution of $\boldsymbol{S n}$ - B bimetallic benzene (e.g. 0.029 M, same procedure for 4-4 before working-up of $\mathrm{HCl}$ with pinacol) was concentrated under reduced pressure. The resulting solid (approx. $0.2 \mathrm{mmol}$ ) was dissolved in $1 \mathrm{~mL}$ of $\mathrm{EtOH} / \mathrm{H}_{2} \mathrm{O}(50 / 50 \mathrm{v} / \mathrm{v}$, degassed by argon), and was added 4-iodobenzonitrile $(\mathbf{1 0}, 0.20 \mathrm{mmol})$ and Pd catalysts $(0.01 \mathrm{or} 0.02 \mathrm{mmol})$. The mixture was stirred at $50{ }^{\circ} \mathrm{C}$ under argon atmosphere for 4 hours, then was allowed to be cooled to room temperature. The solutions were treated with $1 \mathrm{~mL}$ of $1 \mathrm{~N} \mathrm{HCl}$ aq. with $1 \mathrm{~mL}$ of pinacol solution $\left(0.75 \mathrm{M} \mathrm{in} \mathrm{Et}_{2} \mathrm{O}\right)$, and were stirred for 30 minutes at room temperature. After addition of EtOAc $(2 \mathrm{~mL})$, brine $(2 \mathrm{~mL})$, and $n$-tetradecane as an internal standard, the organic phase was analyzed by GC to determine the product yields. In Table 2, entry 6, the product (11) was isolated by flash chromatography. The results are summarized in Table S-3.<smiles>CCCCc1ccc(-c2ccc(C#N)cc2)cc1</smiles><smiles>CC1(C)OB(c2ccc(-c3ccc(C#N)cc3)cc2)OC1(C)C</smiles>

4-Tri-n-butylstannyl-4'-cyanobiphenyl (11). Colorless oil. TLC R 0.76 (hexane/EtOAc 10:1): ${ }^{1} \mathrm{H}$ NMR (400 MHz, $\left.\mathrm{CDCl}_{3}\right) \delta 0.90(\mathrm{t}, J=7.2 \mathrm{~Hz}, 9 \mathrm{H}), 1.09$ (dd, $\left.J=8.0,8.0 \mathrm{~Hz}, 6 \mathrm{H}\right)$, 1.35 (tq, $J=7.2,7.2 \mathrm{~Hz}, 6 \mathrm{H}), 1.53-1.60(\mathrm{~m}, 6 \mathrm{H}), 7.53-7.59(\mathrm{~m}, 4 \mathrm{H}), 7.68-7.73(\mathrm{~m}, 4 \mathrm{H}) ;{ }^{13} \mathrm{C}$ $\operatorname{NMR}\left(100 \mathrm{MHz}, \mathrm{CDCl}_{3}\right) \delta$ 9.7, 13.7, 27.4, 29.1, 110.7, 119.0, 126.5, 127.6, 132.6, 137.2, 138.6, 143.2, 145.8; HRMS (ESI) calcd for $\mathrm{C}_{25} \mathrm{H}_{35} \mathrm{NSnNa}\left[\mathrm{M}+\mathrm{Na}^{+}\right]$: 492.1684, found 492.1684 .

4'-Cyano-4-biphenylboronic acid pinacol ester (12). TLC $\mathrm{R}_{f} 0.43$ (hexane/EtOAc 5:1): ${ }^{1} \mathrm{H}$ NMR (400 MHz, $\left.\mathrm{CDCl}_{3}\right) \delta 1.37$ (s, $\left.12 \mathrm{H}\right), 7.59$ (d, J=8.0 Hz, $\left.2 \mathrm{H}\right), 7.67-7.73(\mathrm{~m}, 4 \mathrm{H}), 7.92$ $(\mathrm{d}, J=8.0 \mathrm{~Hz}, 2 \mathrm{H})$. The spectrum was in a good agreement with that of the previous report. ${ }^{[4]}$ 
<smiles>N#Cc1ccc(-c2ccc(-c3ccc(C#N)cc3)cc2)cc1</smiles>

Table S-3. Cross-Coupling Reactions of Stannyl Aryl Borate with 4-Iodobenzonitrile (10).

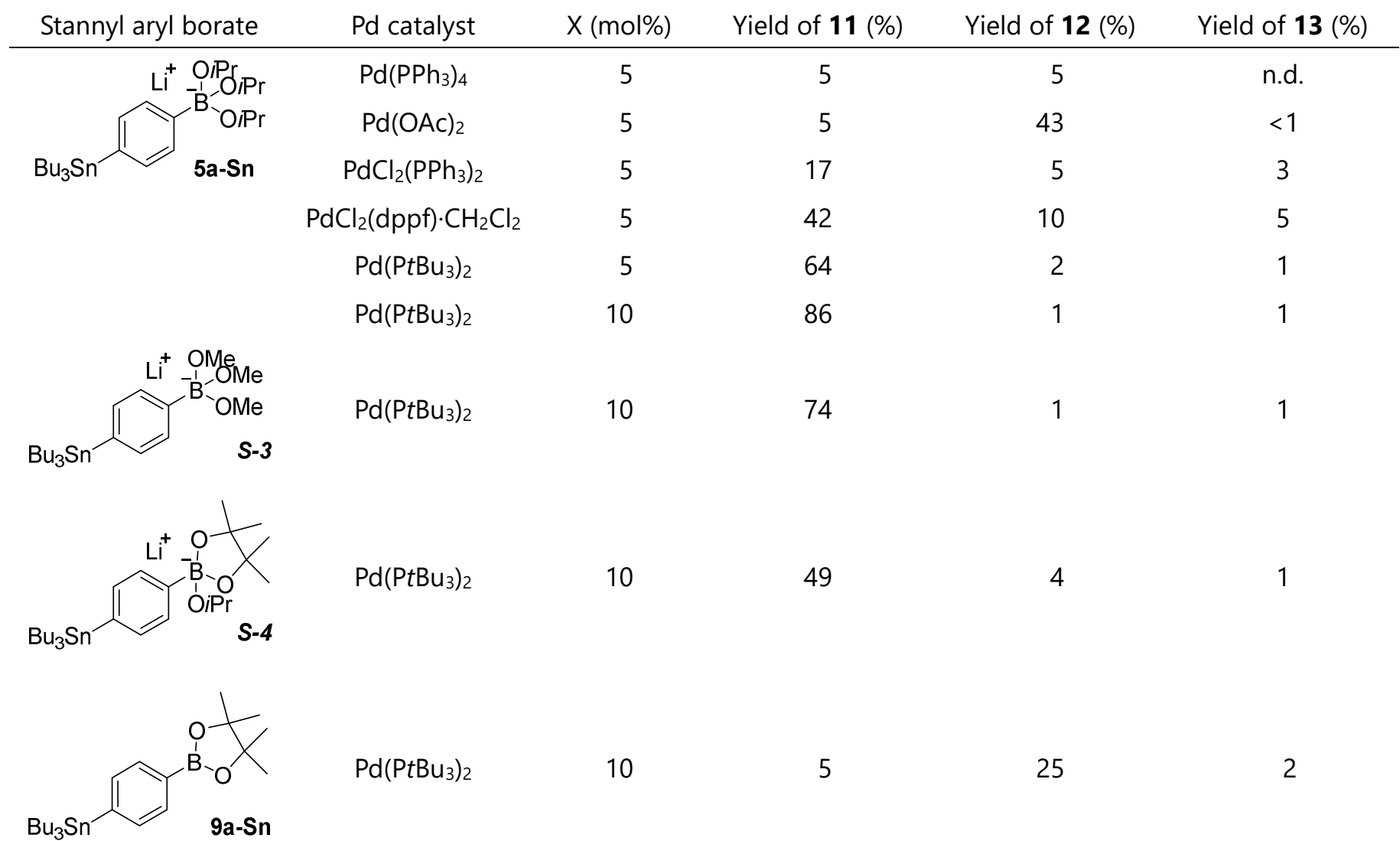

5-2. Cross Coupling Reactions of Stannyl Arylboron-ate Complexes with Aryl lodides.

Typical Procedure for Cross Coupling Reactions of Stannyl Arylboron-ate Complexes with Aryl lodides.

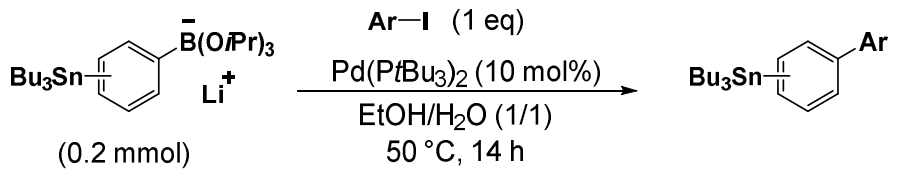

The concentration of stannyl arylboron-ate complexes synthesized by the procedure described in section 4-3 was calculated by a sampling of the solution with was reacted with pinacol to be converted to the corresponding pinacol esters. After concentration under a reduced pressure, the stannyl arylboron-ate complexes (approx. $0.2 \mathrm{mmol}$ ) was dissolved in $1 \mathrm{~mL} \mathrm{of} \mathrm{EtOH} / \mathrm{H}_{2} \mathrm{O}(50 / 50 \mathrm{v} / \mathrm{v}$, degassed by argon), and were added aryl iodide $(0.20 \mathrm{mmol})$ and $\mathrm{Pd}\left(\mathrm{P} t \mathrm{Bu}_{3}\right)_{2}(0.02 \mathrm{mmol})$. The mixture was stirred at $50{ }^{\circ} \mathrm{C}$ under argon atmosphere for 14 hours, then was allowed to be cooled to room temperature. The solutions were treated with $\mathrm{NH}_{4} \mathrm{Cl}(1 \mathrm{~mL})$. After addition of EtOAc $(2 \mathrm{~mL})$, brine $(2 \mathrm{~mL})$, and $n$-tetradecane as an internal standard, the organic phase was analyzed by GC to determine the product yields.<smiles>CCC(C)c1ccc(-c2ccccc2)cc1</smiles>

4-Tri-n-butylstannylbiphenyl (18). The reaction of $\boldsymbol{S}$-2 (0.199 mmol) with phenyl iodide (40.5 $\mathrm{mg}, 0.199 \mathrm{mmol}$ ) provided the title compound in $67 \%$ yield determined by GC; Colorless oil. TLC $\mathrm{R}_{f} 0.68$ (hexane/EtOAc 10:1): ${ }^{1} \mathrm{H}$ NMR (400 MHz, $\left.\mathrm{CDCl}_{3}\right) \delta 0.90(\mathrm{t}, J=7.2 \mathrm{~Hz}, 9 \mathrm{H})$, 
$1.08(\mathrm{dd}, J=8.0,8.0 \mathrm{~Hz}, 6 \mathrm{H}), 1.35(\mathrm{tq}, J=7.2,7.2 \mathrm{~Hz}, 6 \mathrm{H}), 1.47-1.66(\mathrm{~m}, 6 \mathrm{H}), 7.34(\mathrm{tt}, J=$ 2.0, 7.2 Hz, $1 \mathrm{H}), 7.44$ (t, $J=7.6 \mathrm{~Hz}, 2 \mathrm{H}), 7.53-7.58$ (m, $4 \mathrm{H}), 7.60$ (d, J=7.2 Hz, $2 \mathrm{H})$. The NMR spectrum was in a good agreement with the reported one. ${ }^{[6]}$<smiles>CCCCc1ccc(-c2ccc(C)cc2)cc1</smiles><smiles>CCCCc1ccc(-c2ccc(F)cc2)cc1</smiles><smiles>CCC[Sb]c1ccc(-c2cccc3ccccc23)cc1</smiles><smiles>CCC(C)c1cc(C(=O)OC(C)(C)C)cc(-c2ccc(C#N)cc2)c1</smiles>

4-Tri-n-butylstannyl-4'-methylbiphenyl (19). The reaction of $\boldsymbol{S}$-2 (0.199 mmol) with 4iodotoluene $(42.6 \mathrm{mg}, 0.195 \mathrm{mmol})$ provided the title compound in $66 \%$ yield determined by GC; Colorless oil. TLC R 0.68 (hexane/EtOAc 10:1): ${ }^{1} \mathrm{H}$ NMR (400 MHz, $\left.\mathrm{CDCl}_{3}\right) \delta 0.90$ (t, $J$ $=7.2 \mathrm{~Hz}, 9 \mathrm{H}), 1.07$ (dd, $J=8.0,8.0 \mathrm{~Hz}, 6 \mathrm{H}), 1.35$ (tq, $J=7.2,7.2 \mathrm{~Hz}, 6 \mathrm{H}), 1.53-1.60$ (m, 6 H), $2.39(\mathrm{~s}, 3 \mathrm{H}), 7.24$ (d, $J=8.0 \mathrm{~Hz}, 2 \mathrm{H}), 7.47-7.56(\mathrm{~m}, 6 \mathrm{H}) ;{ }^{13} \mathrm{C} \mathrm{NMR}\left(100 \mathrm{MHz}, \mathrm{CDCl}_{3}\right) \delta$ 9.6, 13.7, 21.1, 27.4, 29.1, 126.4, 126.9, 129.4, 136.8 136.9, 138.4, 140.4, 140.6; HRMS (APCI) calcd for $\mathrm{C}_{21} \mathrm{H}_{29} \mathrm{Sn}\left[(\mathrm{M}-\mathrm{Bu})^{+}\right]$: 401.1286 , found 401.1287 .

4-Tri-n-butylstannyl-4'-fluorobiphenyl (20). The reaction of $\boldsymbol{S}-\mathbf{2}(0.199 \mathrm{mmol})$ with 4fluoroiodobenzene $(44.1 \mathrm{mg}, 0.199 \mathrm{mmol})$ provided the title compound in $56 \%$ yield determined by GC; Colorless oil. ${ }^{1} \mathrm{H}$ NMR $\left(400 \mathrm{MHz}, \mathrm{CDCl}_{3}\right) \delta 0.90(\mathrm{t}, J=7.2 \mathrm{~Hz}, 9 \mathrm{H}), 1.08$ $(\mathrm{dd}, J=8.0,8.0 \mathrm{~Hz}, 6 \mathrm{H}), 1.35$ (tq, $J=7.2,7.2 \mathrm{~Hz}, 6 \mathrm{H}), 1.52-1.60(\mathrm{~m}, 6 \mathrm{H}), 7.12$ (dd, $J=8.8$, $8.8 \mathrm{~Hz}, 1 \mathrm{H}), 7.49-7.57(\mathrm{~m}, 6 \mathrm{H})$. The NMR spectrum was in a good agreement with the reported one. ${ }^{[7]}$

Tri-n-butyl-4-(1-naphthyl)phenylstannane (21). The reaction of $\boldsymbol{S}$-2 $(0.199 \mathrm{mmol})$ with 1iodonaphtalene $(50.3 \mathrm{mg}, 0.198 \mathrm{mmol})$ provided the title compound in $58 \%$ yield determined by GC; Colorless oil. ${ }^{1} \mathrm{H}$ NMR $\left(400 \mathrm{MHz}, \mathrm{CDCl}_{3}\right) \delta 0.92(\mathrm{t}, J=7.2 \mathrm{~Hz}, 9 \mathrm{H}), 1.18$ (dd, $J=8.0$, $8.0 \mathrm{~Hz}, 6 \mathrm{H}), 1.37$ (tq, $J=7.6,7.6 \mathrm{~Hz}, 6 \mathrm{H}), 1.51-1.70$ (m, $6 \mathrm{H}), 7.34-7.51$ (m, $6 \mathrm{H}), 7.58$ (d, $J$ $=8.0 \mathrm{~Hz}, 2 \mathrm{H}), 7.82(\mathrm{~d}, J=8.0 \mathrm{~Hz}, 1 \mathrm{H}), 7.87(\mathrm{~d}, J=8.0 \mathrm{~Hz}, 1 \mathrm{H}), 7.95(\mathrm{~d}, J=8.0 \mathrm{~Hz}, 1 \mathrm{H})$; ${ }^{13} \mathrm{C}$ NMR $\left(100 \mathrm{MHz}, \mathrm{CDCl}_{3}\right) \delta 9.6,13.7,27.4,29.1,125.4,125.7,125.9,126.1,126.9,127.5$, 128.2, 129.5, 131.6, 133.8, 136.3, 140.2, 140.3, 140.8; HRMS (ESI) calcd for $\mathrm{C}_{24} \mathrm{H}_{29} \mathrm{Sn}$ $\left[(\mathrm{M}-\mathrm{Bu})^{+}\right]:$437.1286, found 437.1282 .

3-tert-Butoxycarbonyl-5-tri-n-butylstannyl-4'-cyanobiphenyl (22). The reaction of lithium 3-tert-butoxycarbonyl-5-tri- $n$-butylstannylphenyl-triisopropylborate $(\boldsymbol{S}-5,0.199 \mathrm{mmol})$ with 4 iodobenzonitrile $(\mathbf{1 0}, 44.2 \mathrm{mg}, 0.193 \mathrm{mmol})$ provided the title compound in $76 \%$ yield determined by ${ }^{1} \mathrm{H}$ NMR; Colorless oil. ${ }^{1} \mathrm{H}$ NMR (400 MHz, $\left.\mathrm{CDCl}_{3}\right) \delta 0.90(\mathrm{t}, J=7.2 \mathrm{~Hz}, 9 \mathrm{H})$, $1.13(\mathrm{dd}, J=8.0,8.0 \mathrm{~Hz}, 6 \mathrm{H}), 1.35$ (tq, $J=7.2,7.2 \mathrm{~Hz}, 6 \mathrm{H}), 1.41-1.62$ (m, $6 \mathrm{H}), 1.63$ (s, $9 \mathrm{H})$, $7.70(\mathrm{~d}, J=8.4 \mathrm{~Hz}, 2 \mathrm{H}), 7.76(\mathrm{~d}, J=8.4 \mathrm{~Hz}, 2 \mathrm{H}), 7.78(\mathrm{dt}, J=0.4,1.6 \mathrm{~Hz}, 1 \mathrm{H}), 8.10(\mathrm{~d}, J=$ $2.0 \mathrm{~Hz}, 1 \mathrm{H}), .15(\mathrm{dd}, J=0.8,1.6 \mathrm{~Hz}, 1 \mathrm{H}) ;{ }^{13} \mathrm{C} \mathrm{NMR}\left(100 \mathrm{MHz}, \mathrm{CDCl}_{3}\right) \delta$ 9.7, 13.7, 27.3, 28.2, 29.0, 81.3, 111.0, 118.9, 127.9 (two carbons are overlapping), 131.8, 132.6, 137.2, 138.5, 138.8, 143.7, 145.4, 165.8; HRMS (ESI) calcd for $\mathrm{C}_{30} \mathrm{H}_{43} \mathrm{NO}_{2} \mathrm{SnNa}\left[(\mathrm{M}+\mathrm{Na})^{+}\right]$: 592.2208, found 592.2211 . 
5-3. Trial for Cross Coupling Reaction of Lithium Arylboron-Ate Complex 11a-Li.

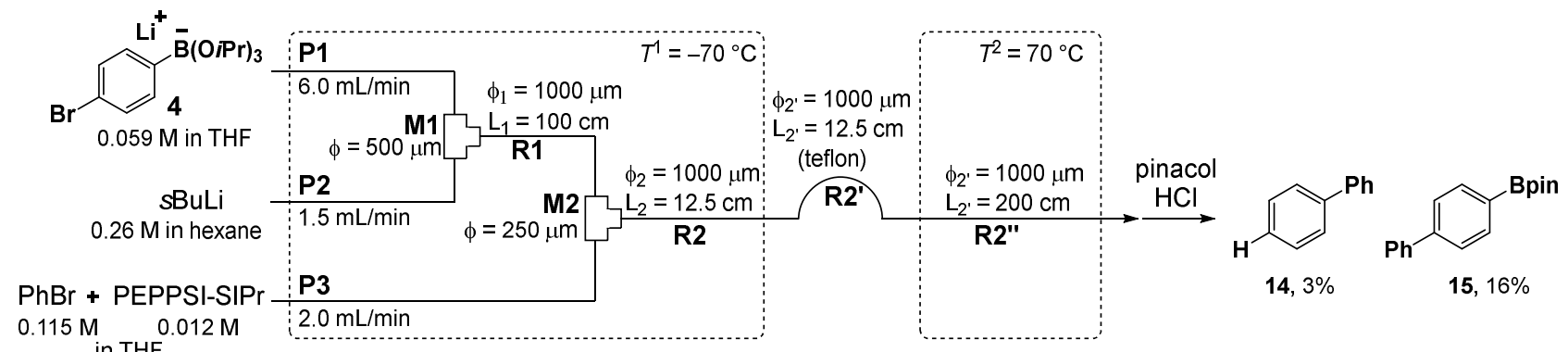

An integrated flow microreactor system consisting of two T-shaped micromixers (M1 and M2), microtube reactors (R1, R2, and R2"), and three pre-cooling units (P1 $(100 \mathrm{~cm}), \mathbf{P 2}(50 \mathrm{~cm})$, and $\mathbf{P 3}(50 \mathrm{~cm}))$ was used. The part of the flow microreactor system composed with P1, P2, P3, M1, M2, R1, and R2 was cooled at $-70{ }^{\circ} \mathrm{C}$ and the tube reactor R2" was heated at $70{ }^{\circ} \mathrm{C}$. Those two parts were connected by PTFE tube R2' $(12.5 \mathrm{~cm})$. Lithium triisopropyl 4-bromophenylborate (4) was synthesized according to the procedure described in section 3 as a $0.059 \mathrm{M}$ solution. The solution of 4 (flow rate: $6.0 \mathrm{~mL} / \mathrm{min}$ ) and a solution of sec-BuLi $(0.26 \mathrm{M}$ in hexane, flow rate: $1.5 \mathrm{~mL} / \mathrm{min})$ were introduced into $\mathbf{M 1}(\phi=500 \mu \mathrm{m})$ by syringe pumps, and the mixture was passed through R1 $\left(100 \mathrm{~cm},-70{ }^{\circ} \mathrm{C}, t^{R 1}=7.2 \mathrm{~s}\right)$. Thus-generated solution (flow rate: $6.5 \mathrm{~mL} / \mathrm{min}$ ) was introduced into $\mathbf{M 2}(\phi=250 \mu \mathrm{m})$ where a THF solution of bromobenzene $(0.115 \mathrm{M})$ with PEPPSI-SIPr $(0.012 \mathrm{M})$ was introduced (flow rate: $2.0 \mathrm{~mL} / \mathrm{min})$. The mixture was passed through $\mathbf{R 2}\left(12.5 \mathrm{~cm},-70{ }^{\circ} \mathrm{C}, t^{\mathrm{R} 2}=0.69 \mathrm{~s}\right)$ and $\mathbf{R 2}$ ' $\left(12.5 \mathrm{~cm}, t^{\mathrm{R} 2}=0.69 \mathrm{~s}\right)$, and was introduced to R2” (200 $\mathrm{cm}, t^{\mathrm{R} 2}$ " $=11 \mathrm{~s}$ ) which was heated at $70^{\circ} \mathrm{C}$. After a steady state was reached ( 30 seconds), an aliquot of the product solution was

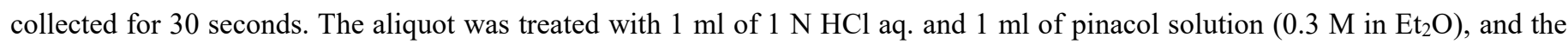
mixture was stirred at r.t. for 30 min to converted a triisopropoxy borate moiety to a pinacolboranyl group. After addition of EtOAc $(2 \mathrm{~mL})$ and brine $(2 \mathrm{~mL}), n$-tetradecane was added, and the organic phase was analyzed by GC to determine the yields of product $14(3 \%)$ and $15(16 \%)$. No multi-adduct was observed.

\section{5-4. Optimization of Cross Coupling Reactions of Zn-B Bimetallic Benzene S-1.}

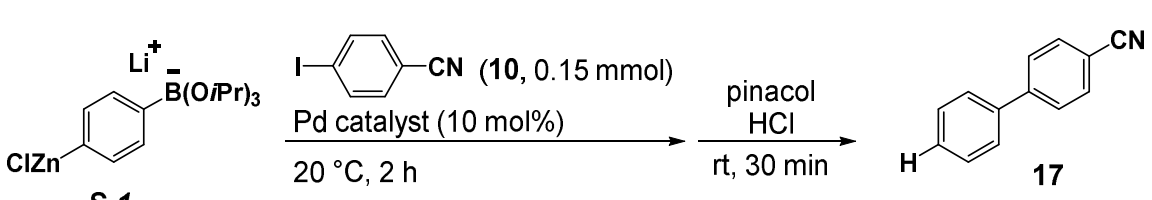

S-1 $20^{\circ} \mathrm{C}, 2 \mathrm{~h}$
$\mathrm{NC}$

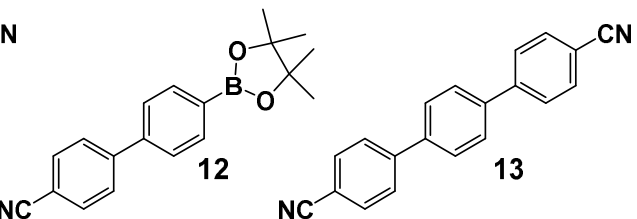

To a flame-dried schlenk tube, were added the aliquot $(6 \mathrm{~mL})$ of the B-Zn bimetallic benzene $\boldsymbol{S}-\mathbf{1}$ (generated by the procedure described in section 5-4), 4-iodobenzonitrile $(\mathbf{1 0}, 0.15 \mathrm{mmol})$, and Pd catalysts $(0.015 \mathrm{mmol})$. The mixture was stirred at $20{ }^{\circ} \mathrm{C}$ under argon atmosphere for 2 hours. Then the solutions were treated with $1 \mathrm{~mL}$ of $1 \mathrm{~N} \mathrm{HCl}$ aq. and $1 \mathrm{~mL}$ of pinacol solution $(0.75$ $\mathrm{M}$ in $\left.\mathrm{Et}_{2} \mathrm{O}\right)$, and were stirred for 30 minutes at room temperature. After addition of EtOAc $(2 \mathrm{~mL})$, brine $(2 \mathrm{~mL})$, and $n$-tetradecane as an internal standard, the organic phase was analyzed by GC to determine the product yields. The result is summarized in Table S-4.

Table S-4. Optimization of Cross-Coupling Reaction of $\boldsymbol{Z n - B}$ Bimetallic Benzene $\boldsymbol{S}$-1 with 4-Iodobenzonitrile (10).

\begin{tabular}{cccc} 
Pd catalyst & Yield of $\mathbf{1 7}(\%)$ & Yield of $\mathbf{1 2}(\%)$ & Yield of $\mathbf{1 3}(\%)$ \\
\hline $\mathrm{Pd}\left(\mathrm{PtBu}_{3}\right)_{2}$ & 1 & 37 & n.d. \\
$\mathrm{PEPPSI}-\mathrm{SIPr}$ & 1 & 23 & n.d. \\
$\mathrm{PdCl}_{2}(\mathrm{dppf}) \cdot \mathrm{CH}_{2} \mathrm{Cl}_{2}$ & 1 & 26 & n.d. \\
$\mathrm{Pd}(\mathrm{OAc})_{2}$ & 2 & 34 & n.d.
\end{tabular}




\section{5-5. Cross Coupling Reactions of Zn-B Bimetallic Arenes with Aryl lodides.}

Cross Coupling of S-6 with 10: Typical Procedure for Cross Coupling Reactions of Zincyl Arylboron-ate Complex with Aryl lodides.
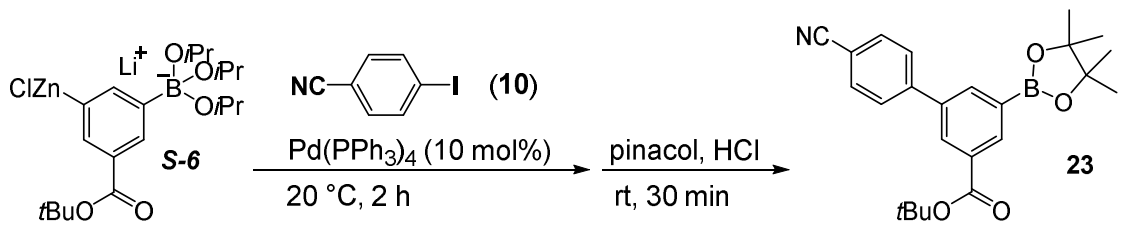

The solution of $\boldsymbol{Z n}-\boldsymbol{B}$ bimetallic arenes ( $8 \mathrm{~mL}$ ) was transferred to a flame-dried schlenk tube. Then, 4-iodobenzonitrile (10, $35.5 \mathrm{mg}$, $0.155 \mathrm{mmol})$ and $\mathrm{Pd}\left(\mathrm{PPh}_{3}\right)_{4}(17 \mathrm{mg}, 0.015 \mathrm{mmol})$ were added. The mixture was stirred at $20{ }^{\circ} \mathrm{C}$ under argon atmosphere for $2 \mathrm{hours}$, then was reacted with pinacol and $1 \mathrm{~N} \mathrm{HCl}$ at room temperature for 30 minutes. After addition of EtOAc $(2 \mathrm{~mL}), \mathrm{brine}(2 \mathrm{~mL})$, the NMR analysis indicated 3-tert-butoxycarbonyl-5-(4-cyanophenyl)phenylboronic acid pinacol ester (23) was obtained in 66\% yield; white solid; ${ }^{1} \mathrm{H}$ NMR (400 MHz, $\left.\mathrm{CDCl}_{3}\right) \delta 1.38(\mathrm{~s}, 12 \mathrm{H}), 1.63(\mathrm{~s}, 9 \mathrm{H}), 7.73-7.78(\mathrm{~m}, 4 \mathrm{H}), 8.18(\mathrm{dd}, J=0.8,2.0 \mathrm{~Hz}, 1 \mathrm{H})$, $8.30(\mathrm{~d}, J=1.6 \mathrm{~Hz}, 2 \mathrm{H}), 8.44(\mathrm{dd}, J=1.2,1.2 \mathrm{~Hz}, 1 \mathrm{H}) ;{ }^{13} \mathrm{C} \mathrm{NMR}\left(100 \mathrm{MHz}, \mathrm{CDCl}_{3}\right) \delta 24.8,28.2,81.5,84.3,111.2,118.8,127.8$, $130.7,132.3,132.6,135.6,137.2,138.6,144.7,165.4$ (one carbon attached to B atom is not visible); HRMS (ESI) calcd for $\mathrm{C}_{24} \mathrm{H}_{28} \mathrm{BNO}_{4} \mathrm{Na}\left[(\mathrm{M}+\mathrm{Na})^{+}\right]:$428.2004, found 428.2002 .

\section{Synthetic Utility of Stannyl Biphenyl 11 and Boryl Biphenyl 12.}

\section{6-1. Iodination of 11.}

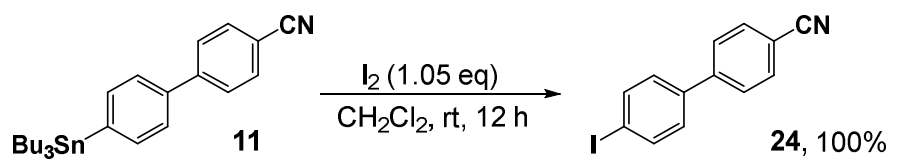

To a $50 \mathrm{~mL}$ round-bottom flask were added 4-tri- $n$-butylstannyl-4'-cyanobiphenyl (11, $92.5 \mathrm{mg}, 0.197 \mathrm{mmol})$, iodine (51.9 mg, $0.204 \mathrm{mmol})$, and dichloromethane $(2 \mathrm{~mL})$. The mixture was stirred at room temperature for 12 hours, and then concentrated under reduced pressure. Dichloromethane $(20 \mathrm{~mL})$ and $\mathrm{Na}_{2} \mathrm{~S}_{2} \mathrm{O}_{3}$ aq $(20 \mathrm{~mL})$ was added, and the mixture was extracted by dichloromethane $(15 \mathrm{~mL} \times 3)$. The combined organic phase was washed by brine $(10 \mathrm{~mL} \times 3)$, and was dried over $\mathrm{Na}_{2} \mathrm{SO}_{4}$. After removal of the solvent under reduced pressure, the desired product, 4-cyano-4'-iodobiphenyl (24) was obtained in quantitative yield (59.9 mg, $0.196 \mathrm{mmol}):{ }^{1} \mathrm{H} \mathrm{NMR}\left(400 \mathrm{MHz}, \mathrm{CDCl}_{3}\right) \delta 7.32(\mathrm{~d}, J=8.4 \mathrm{~Hz}, 2 \mathrm{H}), 7.64(\mathrm{~d}, J=8.4 \mathrm{~Hz}, 2 \mathrm{H}), 7.73(\mathrm{~d}, J=8.4 \mathrm{~Hz}, 2 \mathrm{H}), 7.81(\mathrm{~d}$, $J=8.4 \mathrm{~Hz}, 2 \mathrm{H})$. The NMR analysis was in a good agreement with the reported one. ${ }^{[8]}$

\section{6-2. Stille Coupling Reaction of 11.}
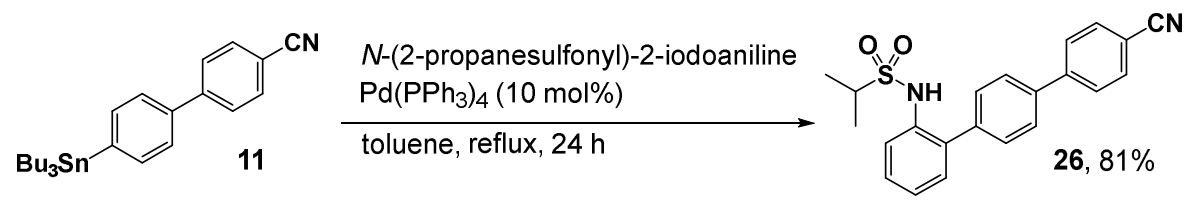

To a $10 \mathrm{~mL}$ schlenk tube, were added 4-tri- $n$-butylstannyl-4'-cyanobiphenyl (11, $94.4 \mathrm{mg}, 0.202 \mathrm{mmol}), N$-(2-propanesulfonyl)-2iodoaniline $(\mathbf{2 5}, 74.5 \mathrm{mg}, 0.229 \mathrm{mmol})$, and dry toluene $(1 \mathrm{~mL})$. After degasification of the mixture by argon gas, 
tetrakis(triphenylphosphine) palladium (0) $(23.8 \mathrm{mg}, 0.021 \mathrm{mmol})$ was added, and the mixture was stirred at $110{ }^{\circ} \mathrm{C}$ for 24 hours under argon atmosphere. Then the reaction mixture was allowed to be cooled at room temperature, and was passed through a silica plug using $2 \% \mathrm{MeOH} / \mathrm{CH}_{2} \mathrm{Cl}_{2}$ as an eluent. After purification by flash chromatography (0 to $\left.1 \% \mathrm{MeOH} / \mathrm{CH}_{2} \mathrm{Cl}{ }_{2}\right), \mathrm{N}$-Isopropyl-(4'"cyano-[1,1';4',1']terphenyl-2-yl)sulfonamide (26). was obtained in 81\% yield as a white solid (61.7 mg, 0.164 mmol); TLC $\mathrm{R}_{f}$ $0.77\left(\mathrm{CH}_{2} \mathrm{Cl}_{2} / \mathrm{MeOH} 50: 1\right):{ }^{1} \mathrm{H} \mathrm{NMR}\left(400 \mathrm{MHz}, \mathrm{CDCl}_{3}\right) \delta 1.27(\mathrm{~d}, J=7.2 \mathrm{~Hz}, 6 \mathrm{H}), 3.28$ (sept, $\left.J=6.8 \mathrm{~Hz}, 1 \mathrm{H}\right), 6.37$ (br, s, $1 \mathrm{H}$ ), $7.20(\mathrm{dt}, J=1.2,7.6 \mathrm{~Hz}, 1 \mathrm{H}), 7.28(\mathrm{dd}, J=1.2,7.6 \mathrm{~Hz}, 1 \mathrm{H}), 7.39(\mathrm{dt}, J=2.0,8.0 \mathrm{~Hz}, 1 \mathrm{H}), 7.49$ (d, $J=7.6 \mathrm{~Hz}, 2 \mathrm{H}), 7.68-7.79$ $(\mathrm{m}, 7 \mathrm{H}) ;{ }^{13} \mathrm{C} \mathrm{NMR}\left(100 \mathrm{MHz}, \mathrm{CDCl}_{3}\right) \delta 16.3,52.8,111.3,118.8,119.1,124.3,127.7,128.2,129.1,129.8,130.6,131.4,132.7$, 134.4, 137.8, 139.1, 144.6; HRMS (ESI) calcd for $\mathrm{C}_{22} \mathrm{H}_{20} \mathrm{~N}_{2} \mathrm{SO}_{2} \mathrm{Na}\left[\mathrm{M}+\mathrm{Na}^{+}\right]$: 399.1138, found 399.1141.

\section{6-3. Hydroxylation of 12.}
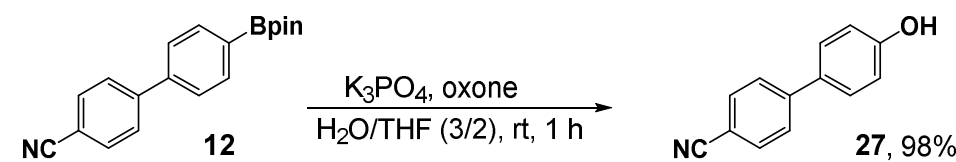

To a vial, were added 4'-cyano-4-biphenylboronic acid pinacol ester (12, $48.8 \mathrm{mg}, 0.160 \mathrm{mmol})$, oxone (246 mg, $0.4 \mathrm{mmol}), \mathrm{K}_{3} \mathrm{PO}_{4}$ (102 $\mathrm{mg}, 0.48 \mathrm{mmol})$, THF $(0.8 \mathrm{~mL})$, and water $(1.2 \mathrm{~mL})$. The mixture was stirred at room temperature for 1 hour under air vigorously, and then the reaction was quenched by the addition of $\mathrm{Na}_{2} \mathrm{~S}_{2} \mathrm{O}_{5}$. The organic layer was extracted with EtOAc, was dried over $\mathrm{MgSO}_{4}$, and was concentrated in vacuo. The crude solid was washed with hexane twice, and then dissolved in chloroform. The solution was filtered by a celite plug, and was concentrated in vacuo to afford 4-hydroxy-4'-cyanobiphenyl (27, 30.7 mg, 0.157 mmol) in 98\% yield as a white solid; ${ }^{1} \mathrm{H}$ NMR (400 MHz, $\left.\mathrm{CDCl}_{3}\right) \delta 5.08$ (br, $\left.1 \mathrm{H}\right), 6.94(\mathrm{~d}, J=8.4 \mathrm{~Hz}, 2 \mathrm{H}), 7.50(\mathrm{~d}, J=8.8 \mathrm{~Hz}, 2$ $\mathrm{H}), 7.63(\mathrm{~d}, J=8.4 \mathrm{~Hz}, 2 \mathrm{H}), 7.70(\mathrm{~d}, J=8.8 \mathrm{~Hz}, 2 \mathrm{H})$. The NMR spectrum was in a good agreement with the reported one. ${ }^{[9]}$

\section{6-4. Azidation of 12 .}
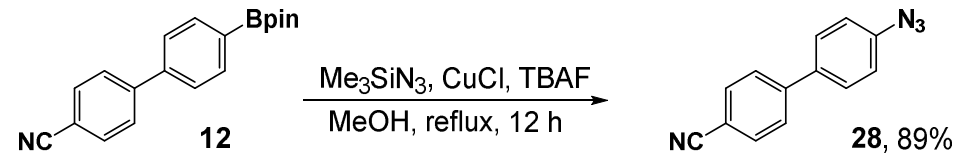

To a $50 \mathrm{~mL}$ round-bottomed flask, were added 4'-cyano-4-biphenylboronic acid pinacol ester (12, $46.0 \mathrm{mg}, 0.151 \mathrm{mmol})$, trimethylsilyl azide (27 $\mu \mathrm{L}, 0.205 \mathrm{mmol}), \mathrm{CuCl}(2 \mathrm{mg}, 0.02 \mathrm{mmol}), \mathrm{TBAF}(1 \mathrm{M}$ in THF, $0.2 \mathrm{~mL}, 0.2 \mathrm{mmol})$, and methanol (1 mL). The mixture was stirred at $80{ }^{\circ} \mathrm{C}$ for 12 hours. The reaction mixture was concentrated, and was passed through a silica plug with 10\% EtOAc/hexane as an eluent. After removal of the solvent under reduced pressure, the desired product 4-azido-4'cyanobiphenyl (28) was obtained in $89 \%$ yield $(29.5 \mathrm{mg}, 0.134 \mathrm{mmol})$ as a yellowish solid; ${ }^{1} \mathrm{H} \mathrm{NMR}\left(400 \mathrm{MHz}, \mathrm{CDCl}_{3}\right) \delta 7.14(\mathrm{~d}$, $J=8.8 \mathrm{~Hz}, 2 \mathrm{H}), 7.59(\mathrm{~d}, J=8.8 \mathrm{~Hz}, 2 \mathrm{H}), 7.66(\mathrm{~d}, J=8.8 \mathrm{~Hz}, 2 \mathrm{H}), 7.72(\mathrm{~d}, J=8.8 \mathrm{~Hz}, 2 \mathrm{H})$. The NMR spectrum was in a good agreement with the reported one. ${ }^{[10]}$

\section{References.}

[1] Wrackmeyer, B. Prog. Nucl. Magn. Reson. Spectrosc. 1979, 12, 227.

[2] Yamazaki, Y.; Ajioka, N.; Yokoyama, A.; Yokozawa, T. Macromolecules 2009, 42, 606.

[3] Tsoi, Y.-T.; Zhou, Z.; Yu, W.-Y. Org. Lett. 2011, 13, 5370.

[4] Lindner, M.; Valášek, M.; Mayor, M.; Frauhammer, T.; Wulfhekel, W.; Gerhard, L. Angew. Chem. Int. Ed. $2017,56,8290$.

[5] Ismail, M. A.; Arafa, R. K.; Brun, R.; Wenzler, T.; Miao, Y.; Wilson, W. D.; Generaux, C.; Bridges, A.; Hall, J. E.; Boykin, D. 
W. J. Med. Chem. 2006, 49, 5324.

[6] Furuya, T.; Strom, A. E.; Ritter, T. J. Am. Chem. Soc. 2009, 131, 1662.

[7] Yue, H.; Zhu, C.; Rueping, M. Org. Lett. 2018, 20, 385.

[8] Schiek, M.; Al-Shamery, K.; Lützen, A. Synthesis 2007, 613.

[9] Dutronc, T.; Terazzi, E.; Guénée, L.; Buchwalder, K.-L.; Spoerri, A.; Emery, D.; Mareda, J.; Floquet, S.; Piguet, C. Chem. Eur. J. 2013, $19,8447$.

[10] Hommersom, C. A.; Matt, B.; van der Ham, A.; Cornelissena, J. J. L. M.; Katsonis, N. Org. Biomol. Chem. 2014, 12, 4065. 
8. ${ }^{1} \mathrm{H}$ and ${ }^{13} \mathrm{C}$ NMR Spectra

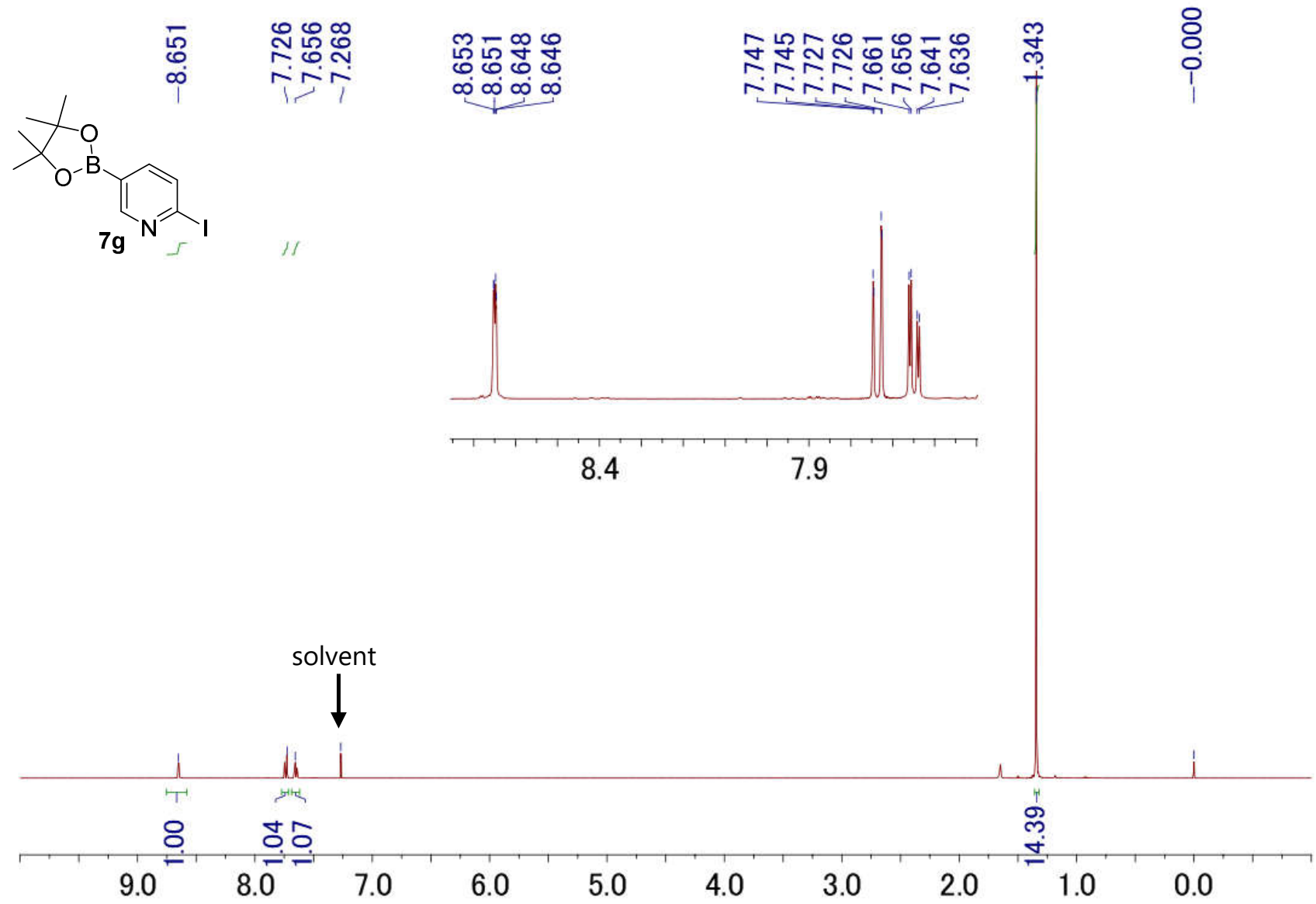

${ }^{1} \mathrm{H}$ NMR spectrum of 2-iodopyridyl-5-boronic acid pinacol ester (7g) $\left(400 \mathrm{MHz}, \mathrm{CDCl}_{3}\right)$.
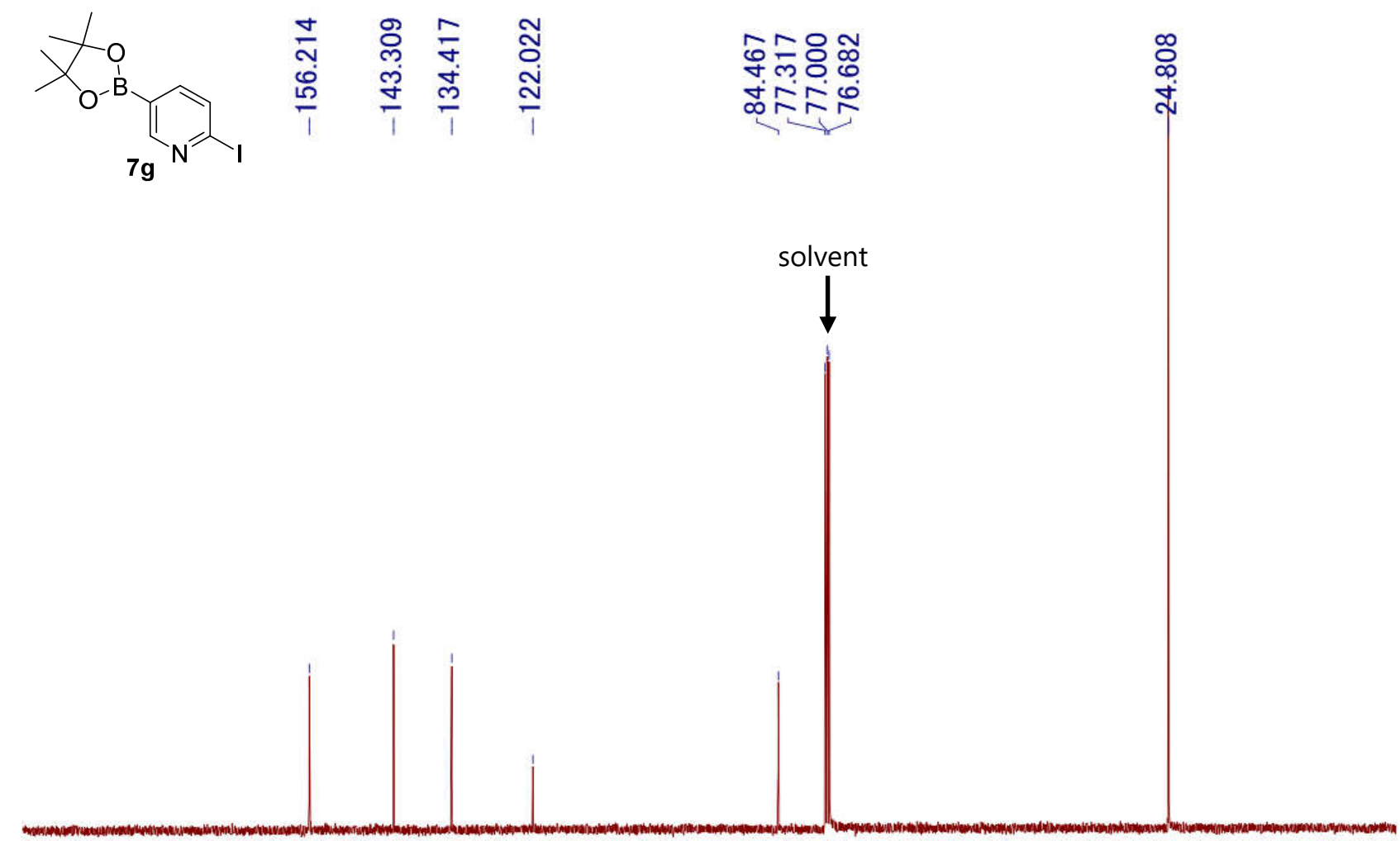

00 180 160 140 120 100

80

60

40

20

0

${ }^{13} \mathrm{C}$ NMR spectrum of 2-iodopyridyl-5-boronic acid pinacol ester $(7 \mathrm{~g})\left(100 \mathrm{MHz}, \mathrm{CDCl}_{3}\right)$. 


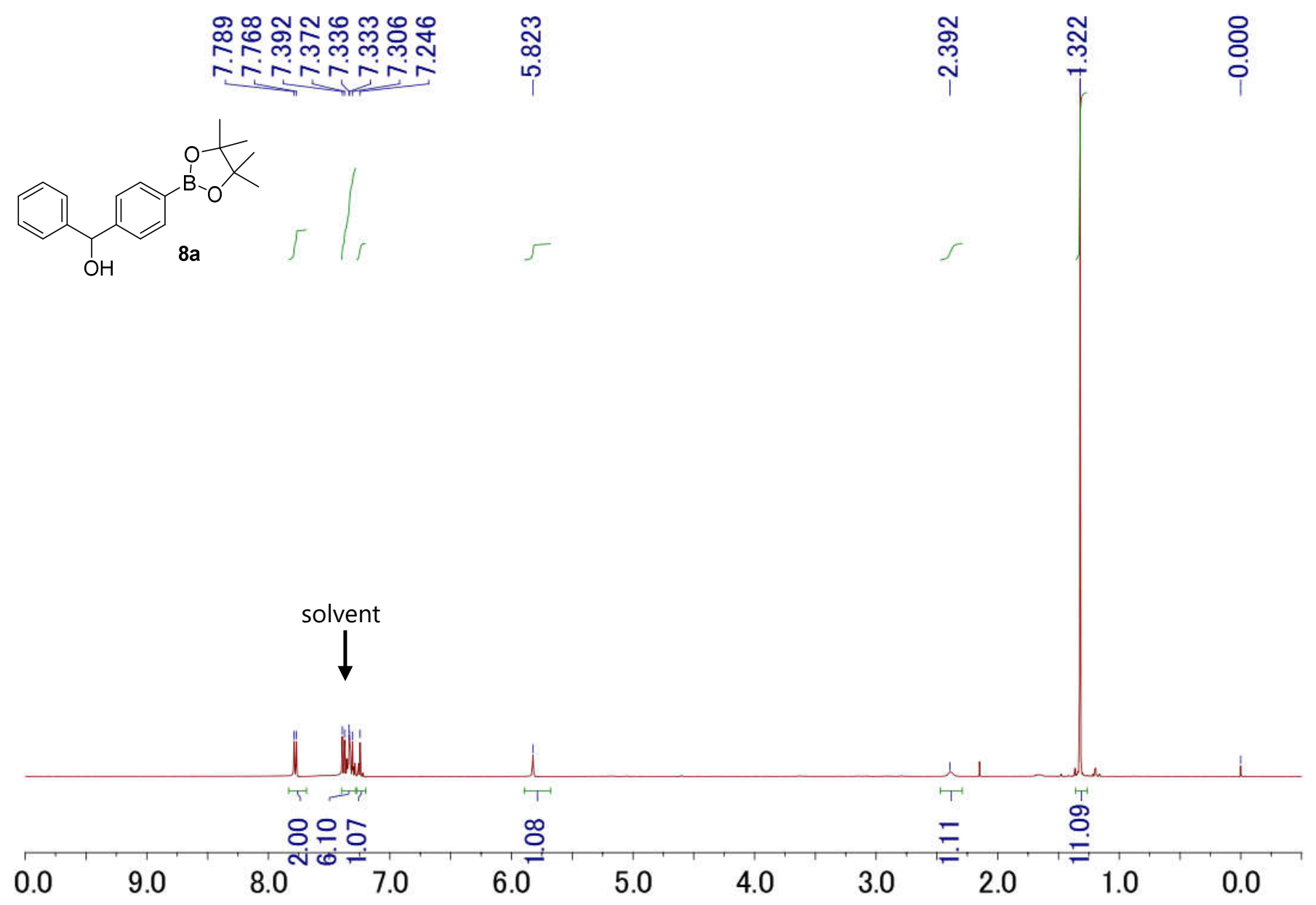

${ }^{1} \mathrm{H}$ NMR spectrum of 4-(4,4,5,5-Tetramethyl-1,3,2-dioxaborolan-2-yl)benzhydrol (8a) (400 $\left.\mathrm{MHz} \mathrm{CDCl}_{3}\right)$.
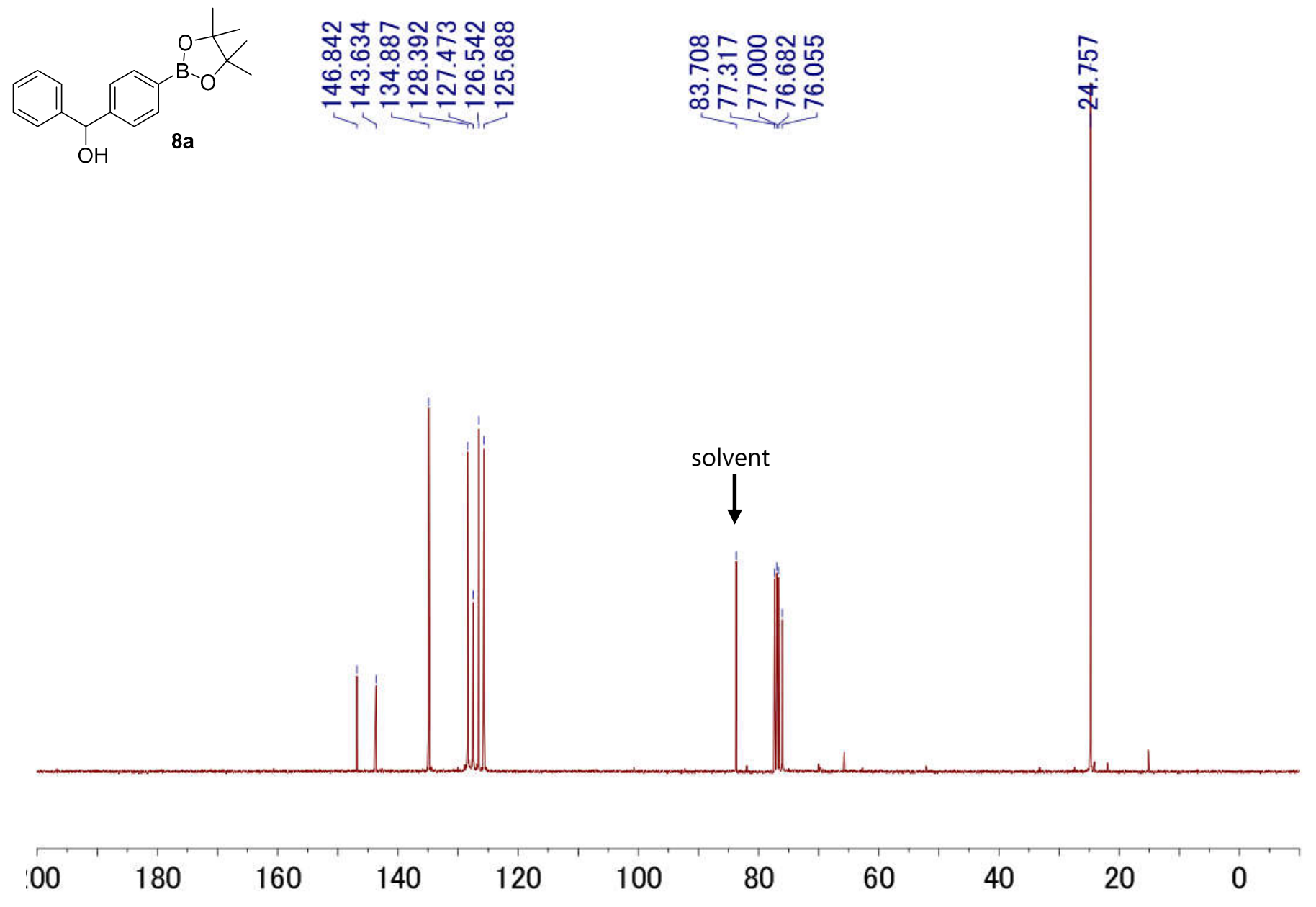

${ }^{13} \mathrm{C}$ NMR spectrum of 4-(4,4,5,5-Tetramethyl-1,3,2-dioxaborolan-2-yl)benzhydrol (8a) (100 $\left.\mathrm{MHz}, \mathrm{CDCl}_{3}\right)$. 


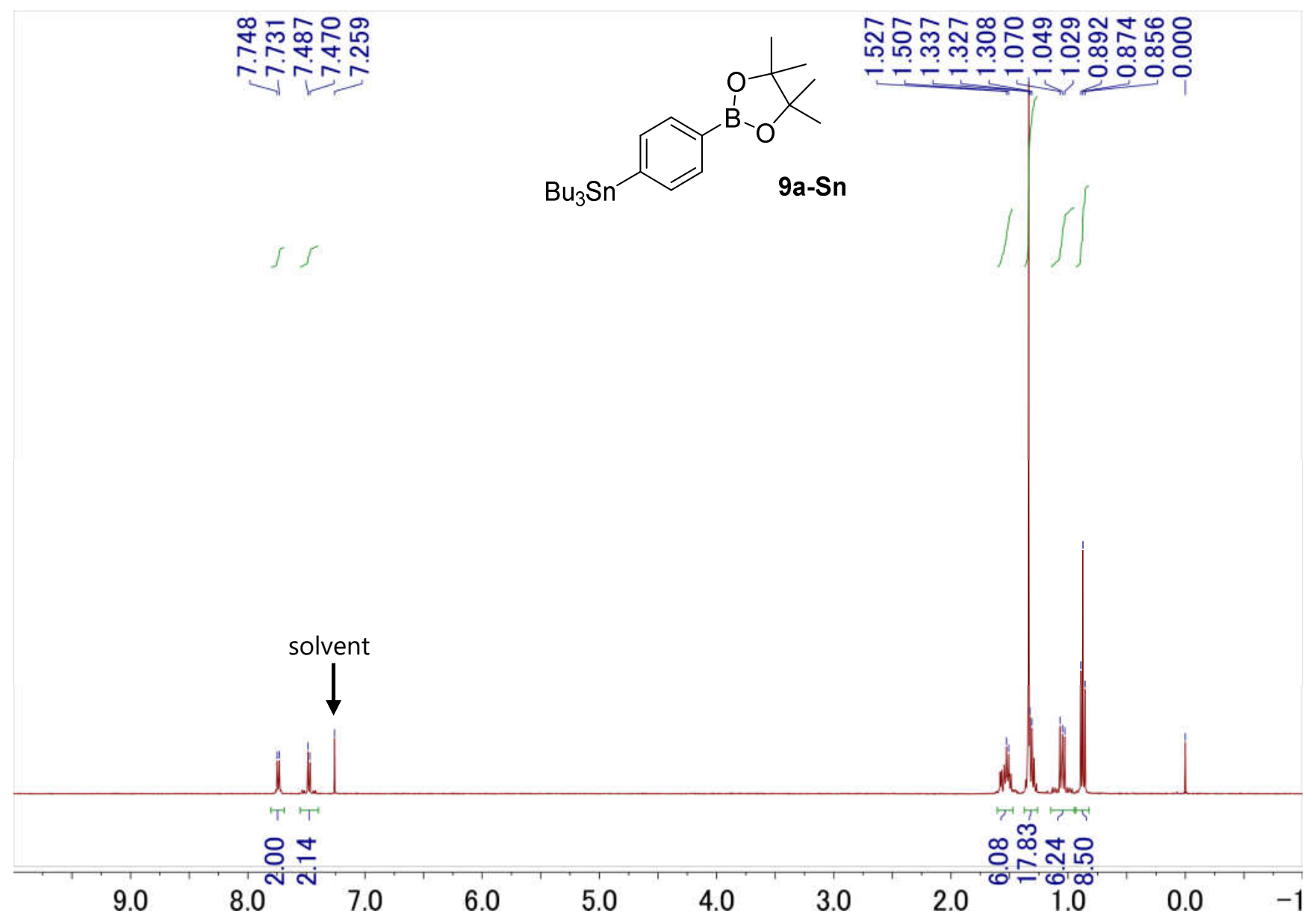

${ }^{1} \mathrm{H}$ NMR spectrum of 4-tri-n-butylstannylphenylboronic acid pinacol ester (9a-Sn) (400 $\left.\mathrm{MHz}, \mathrm{CDCl}_{3}\right)$.
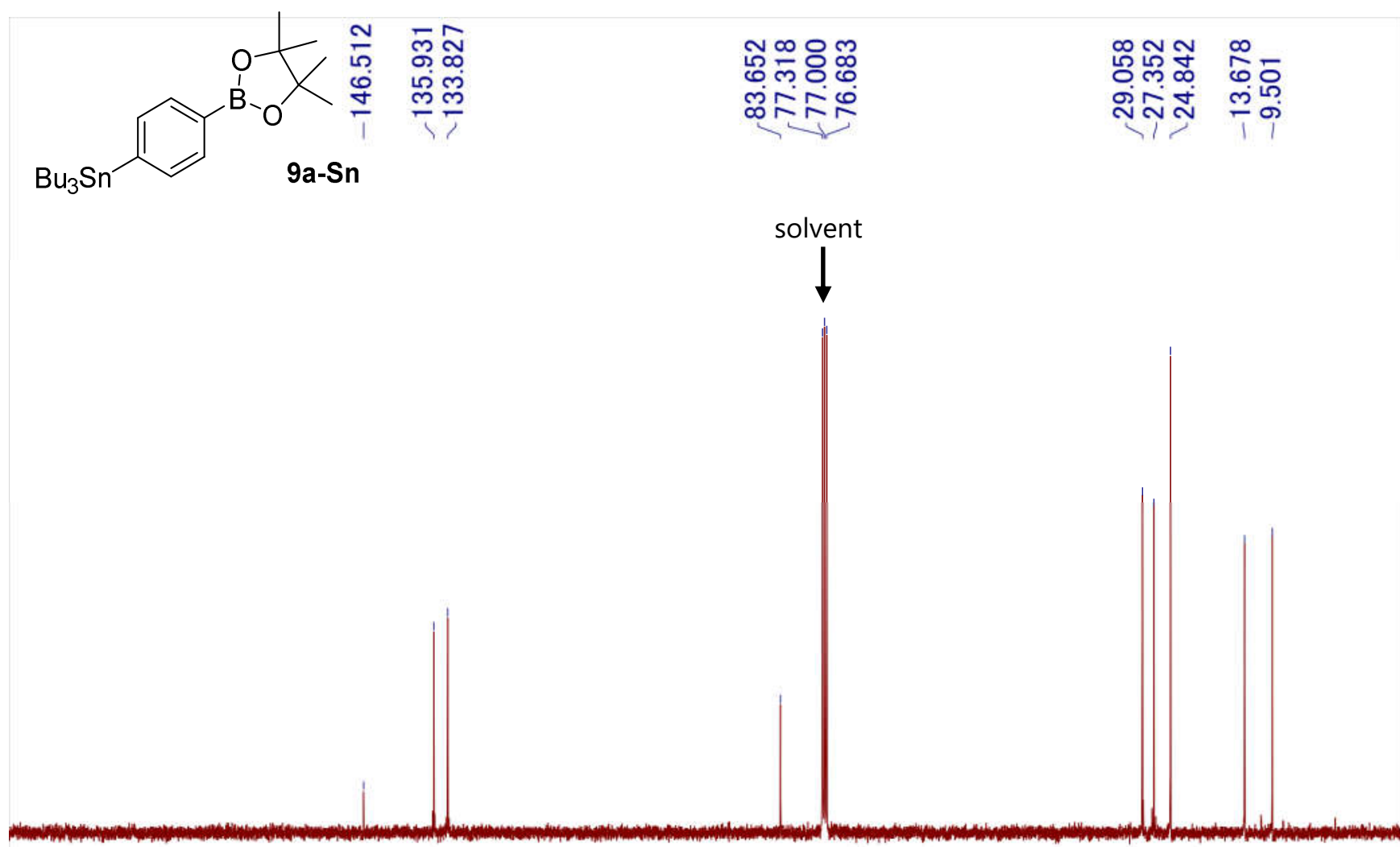

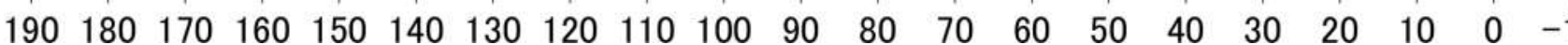

${ }^{13} \mathrm{C}$ NMR spectrum of 4-tri-n-butylstannylphenylboronic acid pinacol ester (9a-Sn) (100 $\left.\mathrm{MHz}, \mathrm{CDCl}_{3}\right)$. 


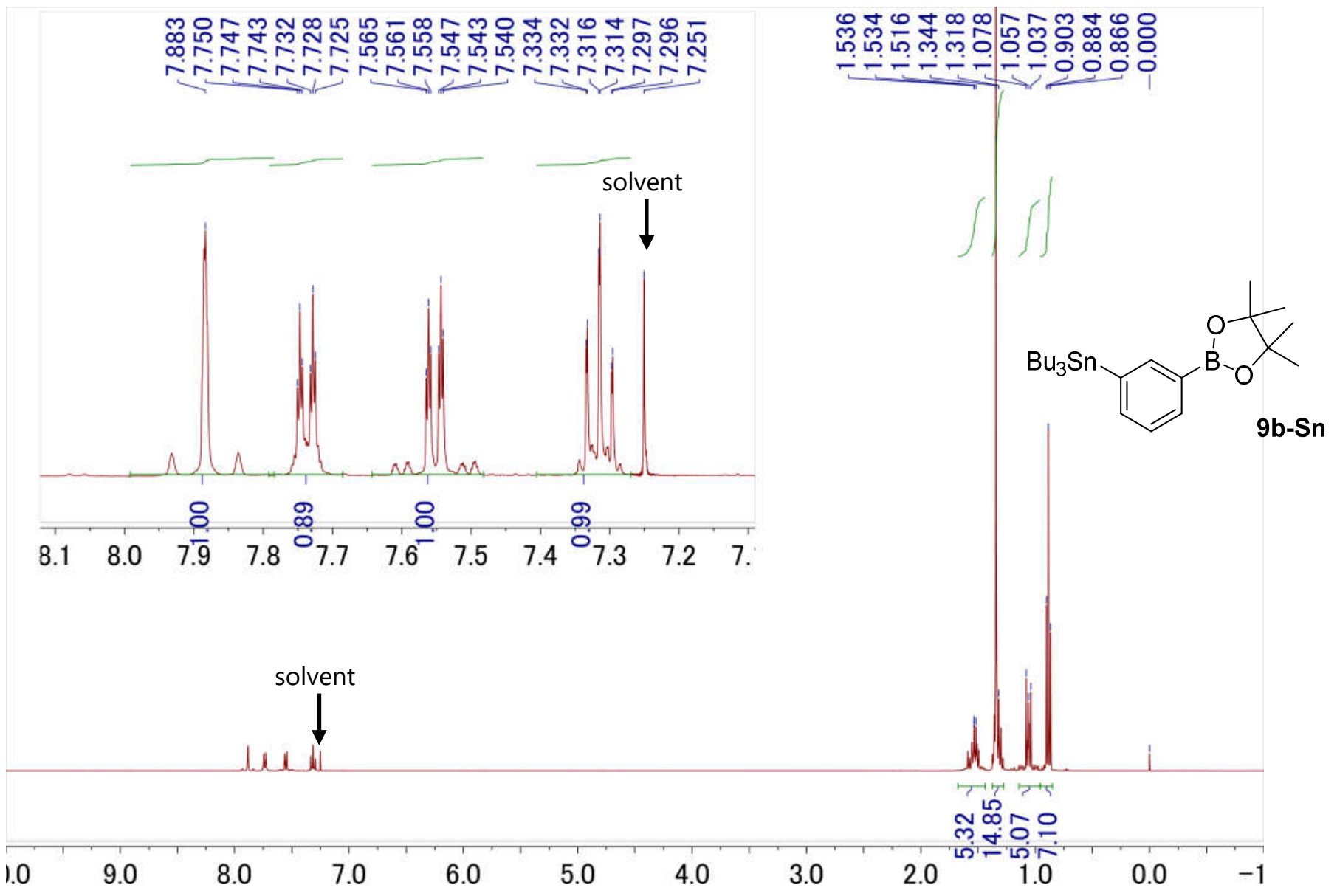

${ }^{1} \mathrm{H}$ NMR spectrum of 3-tri-n-butylstannylphenylboronic acid pinacol ester (9b-Sn) (400 MHz, $\left.\mathrm{CDCl}_{3}\right)$.

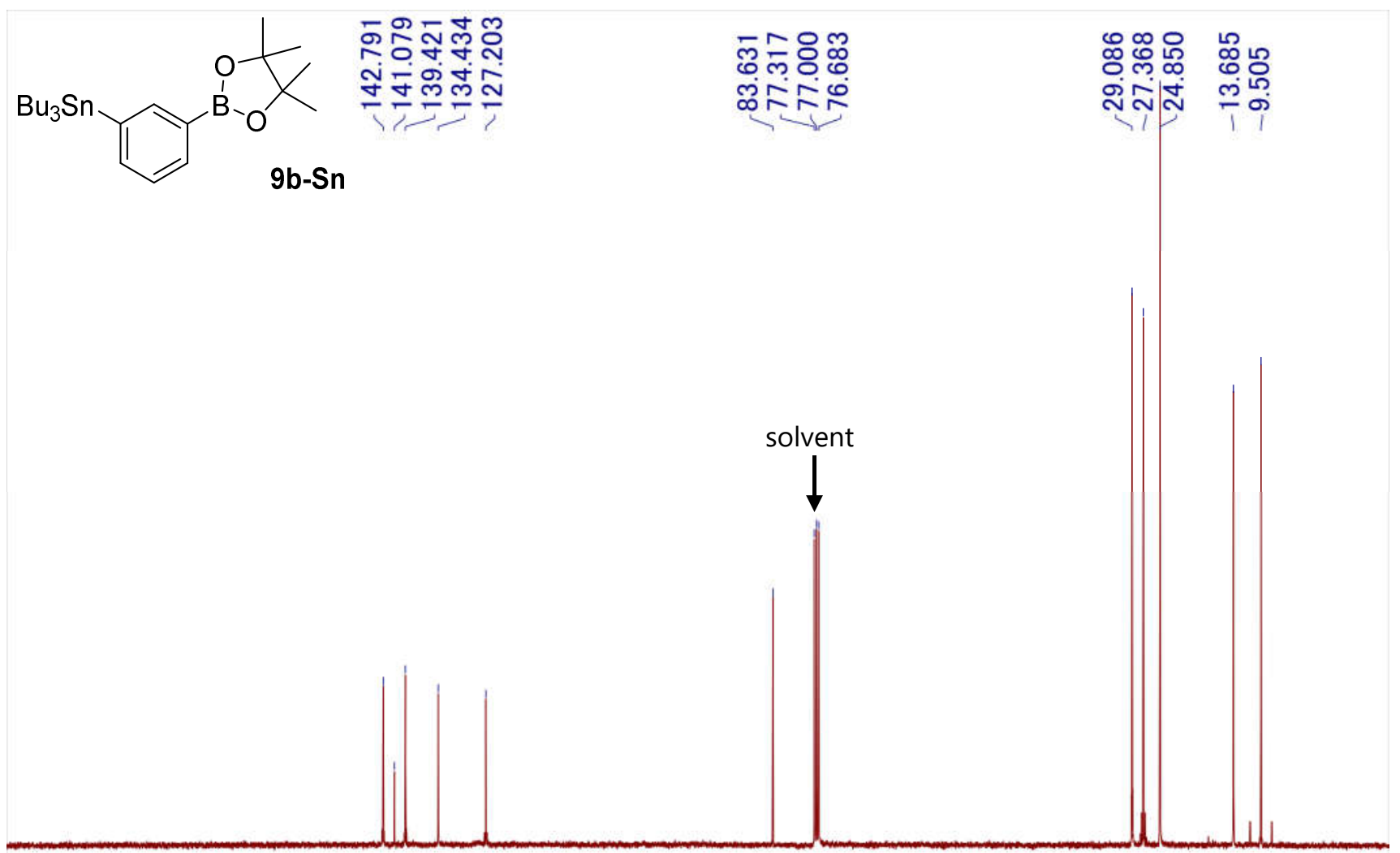

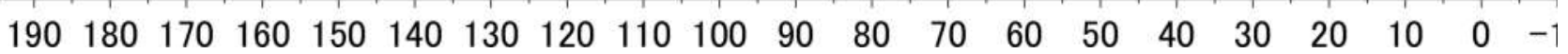

${ }^{13} \mathrm{C}$ NMR spectrum of 3-tri-n-butylstannylphenylboronic acid pinacol ester (9b-Sn) (100 $\left.\mathrm{MHz}, \mathrm{CDCl}_{3}\right)$. 


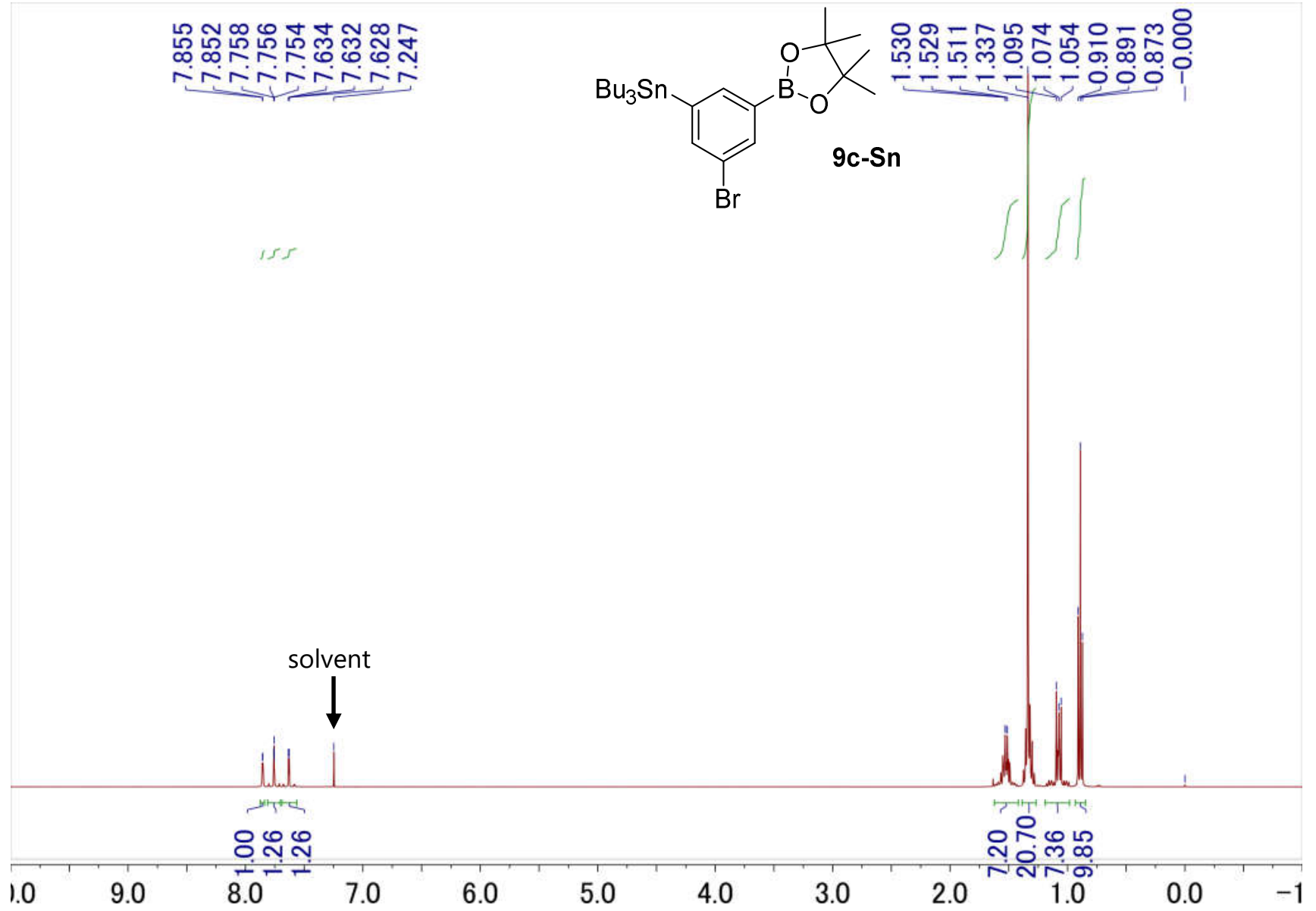

${ }^{1} \mathrm{H}$ NMR spectrum of 3-bromo-5-tri-n-butylstannylphenylboronic acid pinacol ester (9c-Sn) (400 $\left.\mathrm{MHz}, \mathrm{CDCl}_{3}\right)$.

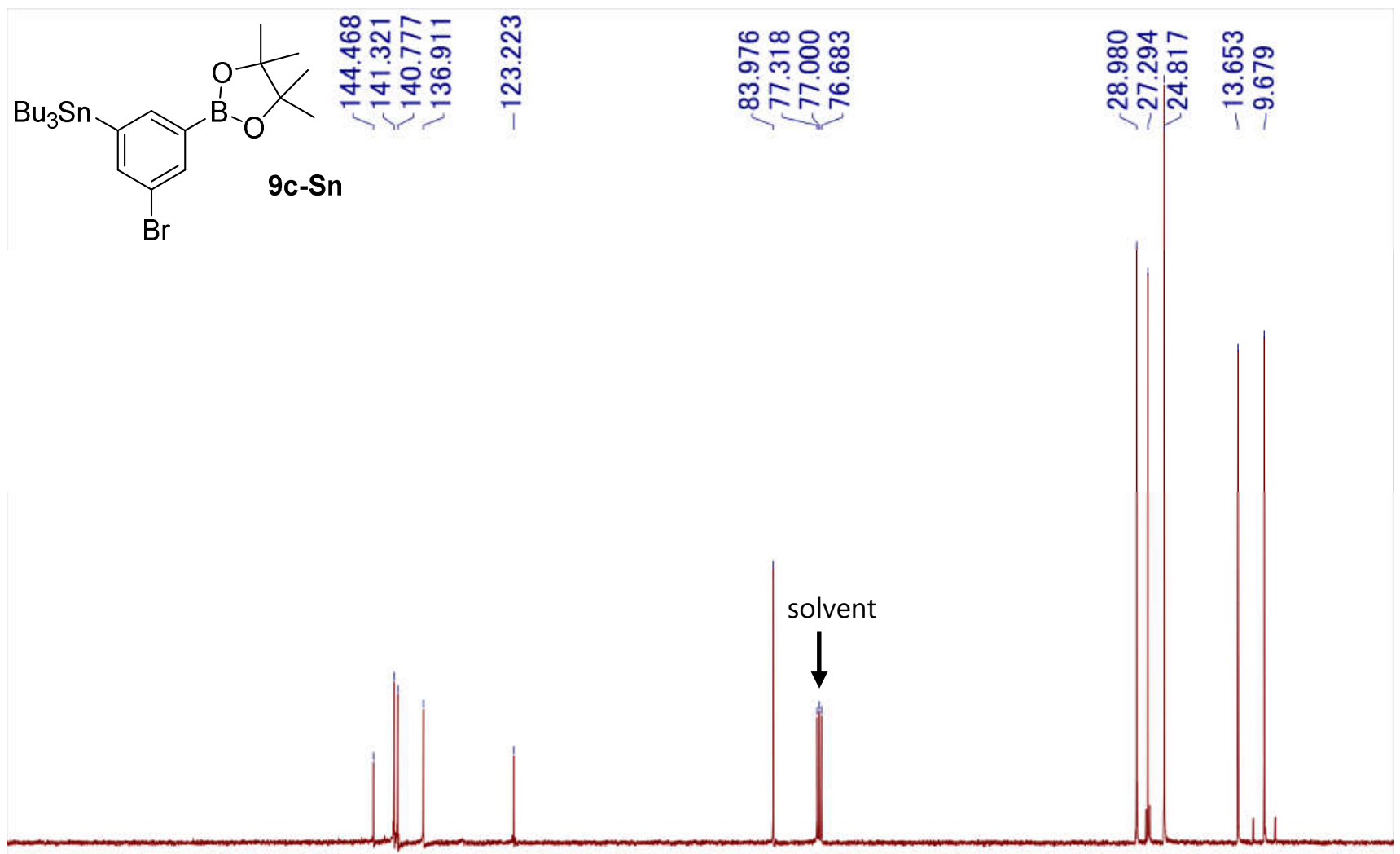

$\begin{array}{lllllllllllllllllllll}190 & 180 & 170 & 160 & 150 & 140 & 130 & 120 & 110 & 100 & 90 & 80 & 70 & 60 & 50 & 40 & 30 & 20 & 10 & 0 & -1\end{array}$

${ }^{13} \mathrm{C}$ NMR spectrum of 3-bromo-5-tri-n-butylstannylphenylboronic acid pinacol ester (9c-Sn) (100 $\mathrm{MHz}_{\mathrm{CDCl}} \mathrm{CD}_{3}$ 


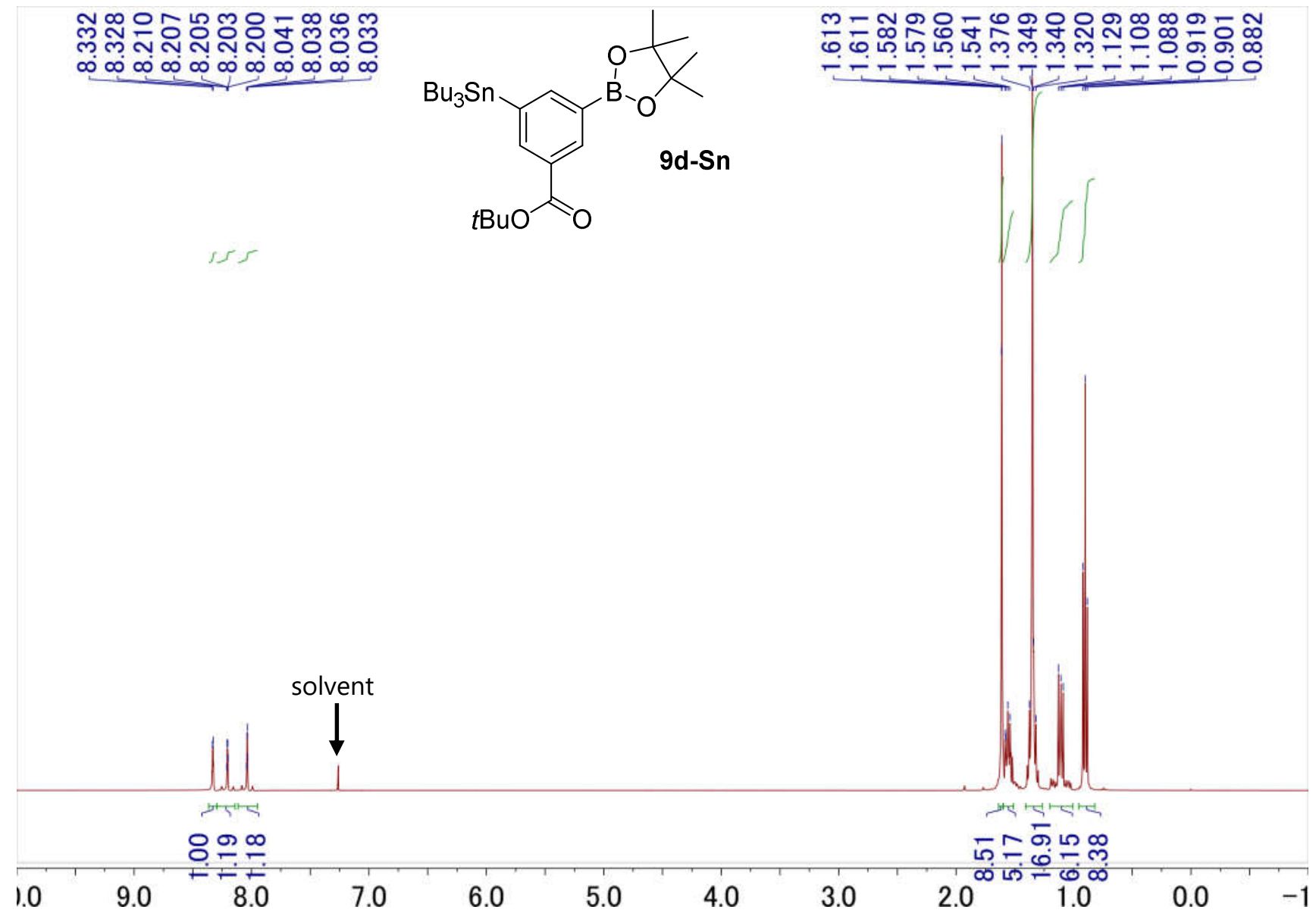

${ }^{1} \mathrm{H}$ NMR spectrum of 3-tert-butyl-5-tri-n-butylstannylphenylboronic acid pinacol ester (9d-Sn) (400 $\left.\mathrm{MHz} \mathrm{CDCl}_{3}\right)$.

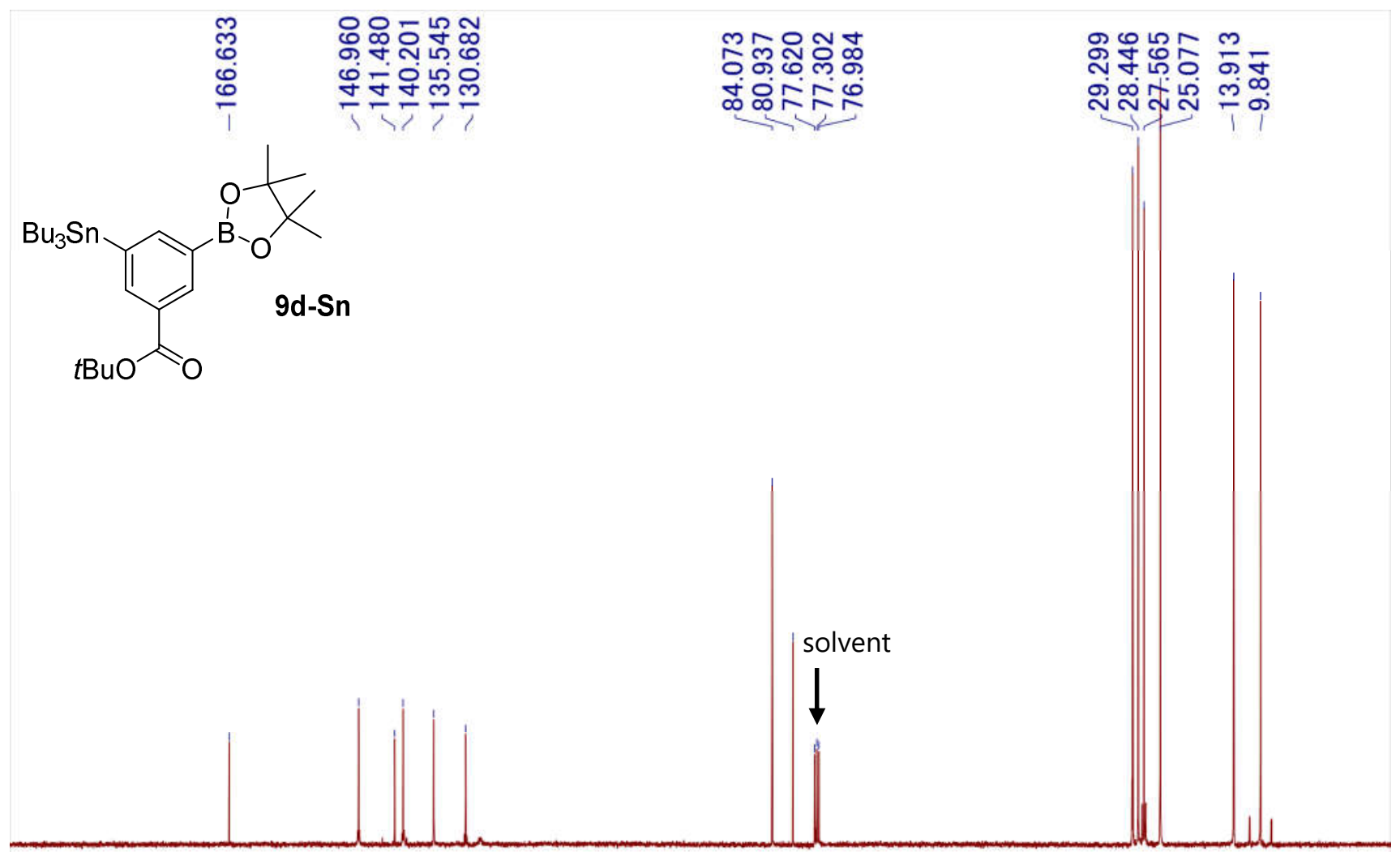

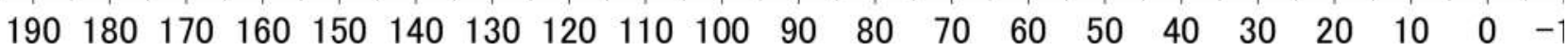

${ }^{13} \mathrm{C}$ NMR spectrum of 3-tert-butyl-5-tri-n-butylstannylphenylboronic acid pinacol ester (9d-Sn) (100 $\left.\mathrm{MHz} \mathrm{CDCl}_{3}\right)$. 


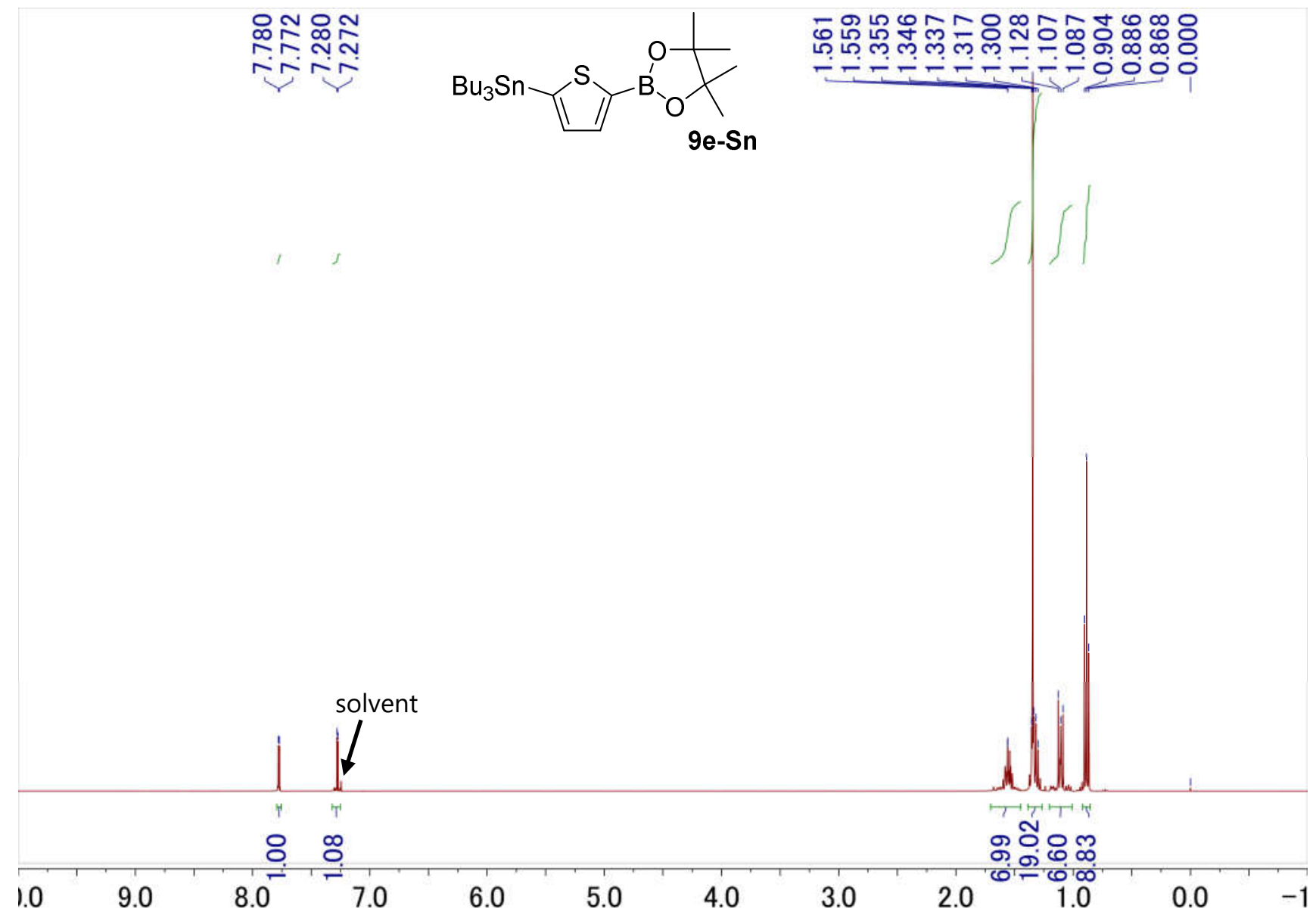

${ }^{1} \mathrm{H}$ NMR spectrum of 5-tri-n-butylstannyl-2-thiopheneboronic acid pinacol ester (9e-Sn) (400 $\mathrm{MHz}^{\left.-\mathrm{CDCl}_{3}\right)}$

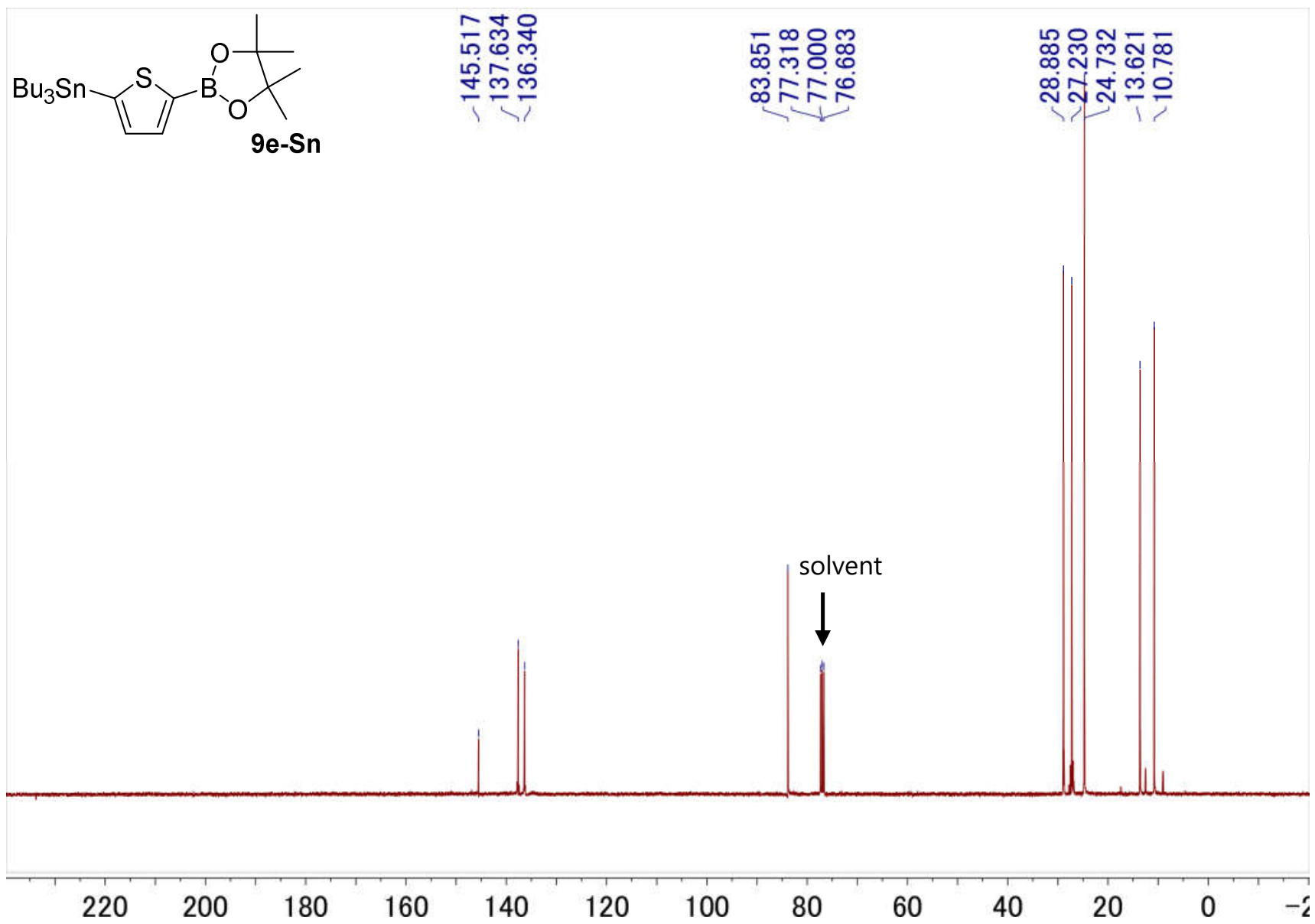

${ }^{13} \mathrm{C}$ NMR spectrum of 5-tri-n-butylstannyl-2-thiopheneboronic acid pinacol ester (9e-Sn) (100 $\left.\mathrm{MHz}, \mathrm{CDCl}_{3}\right)$. 


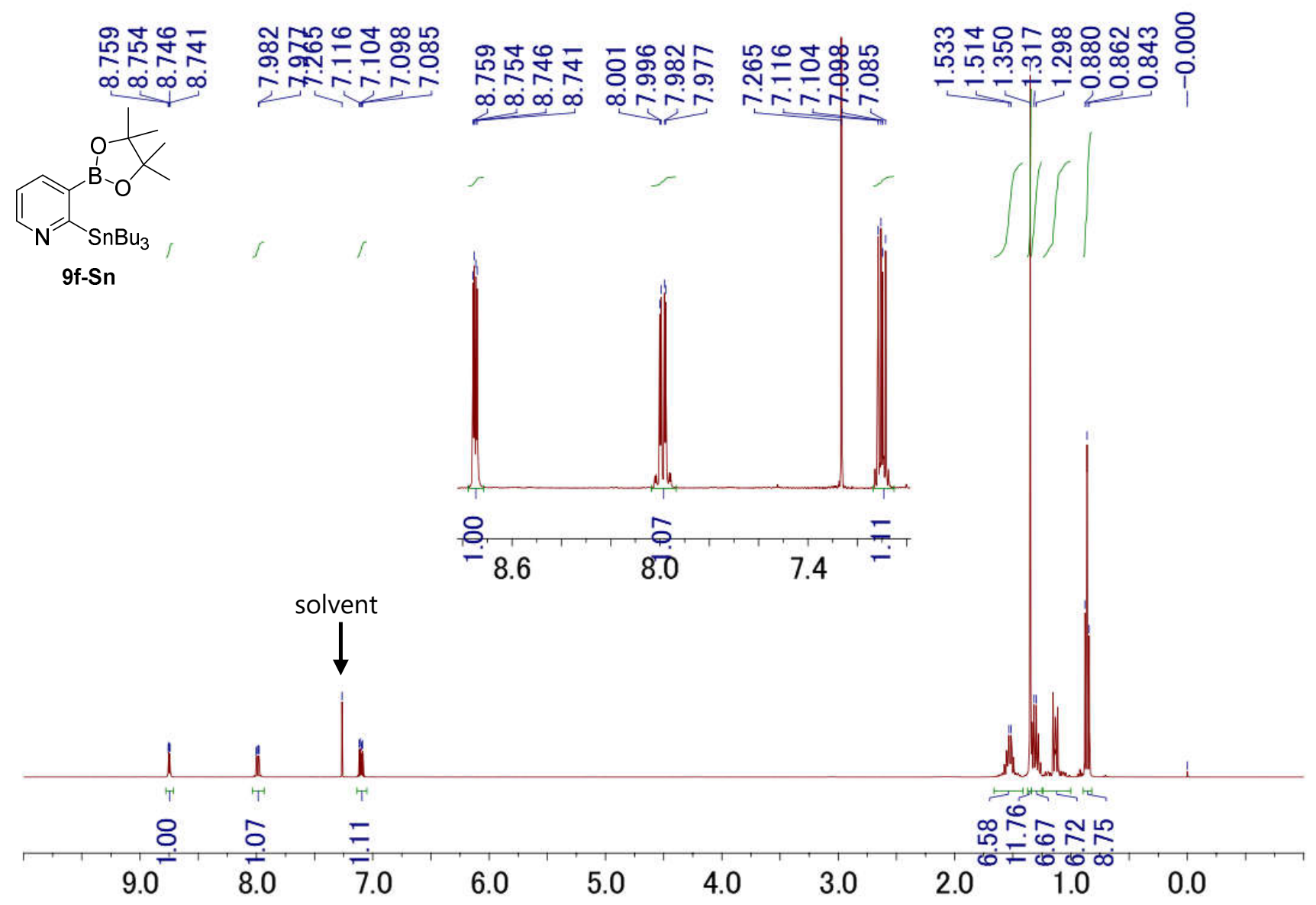

${ }^{1} \mathrm{H}$ NMR spectrum of 2-tri-n-butylstannylpyridin-3-boronic acid pinacol ester (9f-Sn) (400 $\left.\mathrm{MHz}_{3} \mathrm{CDCl}_{3}\right)$.

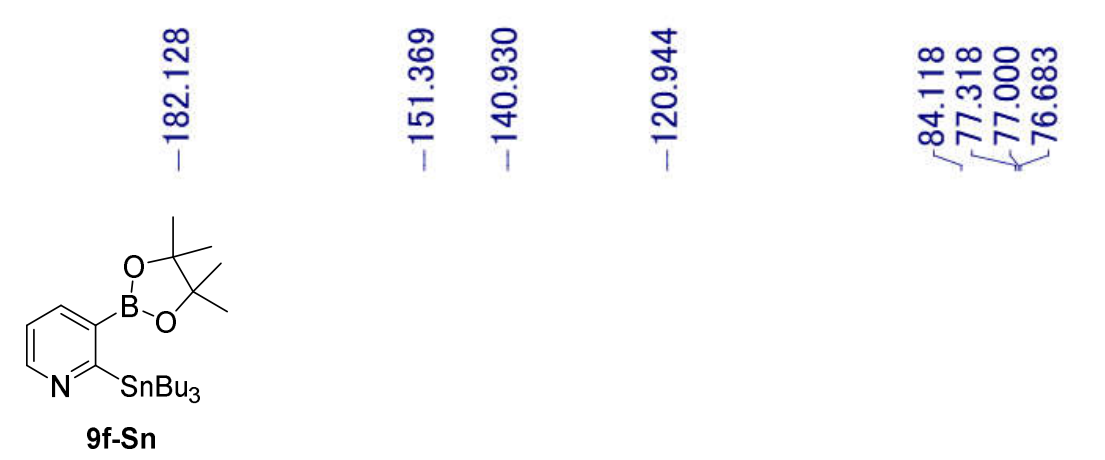




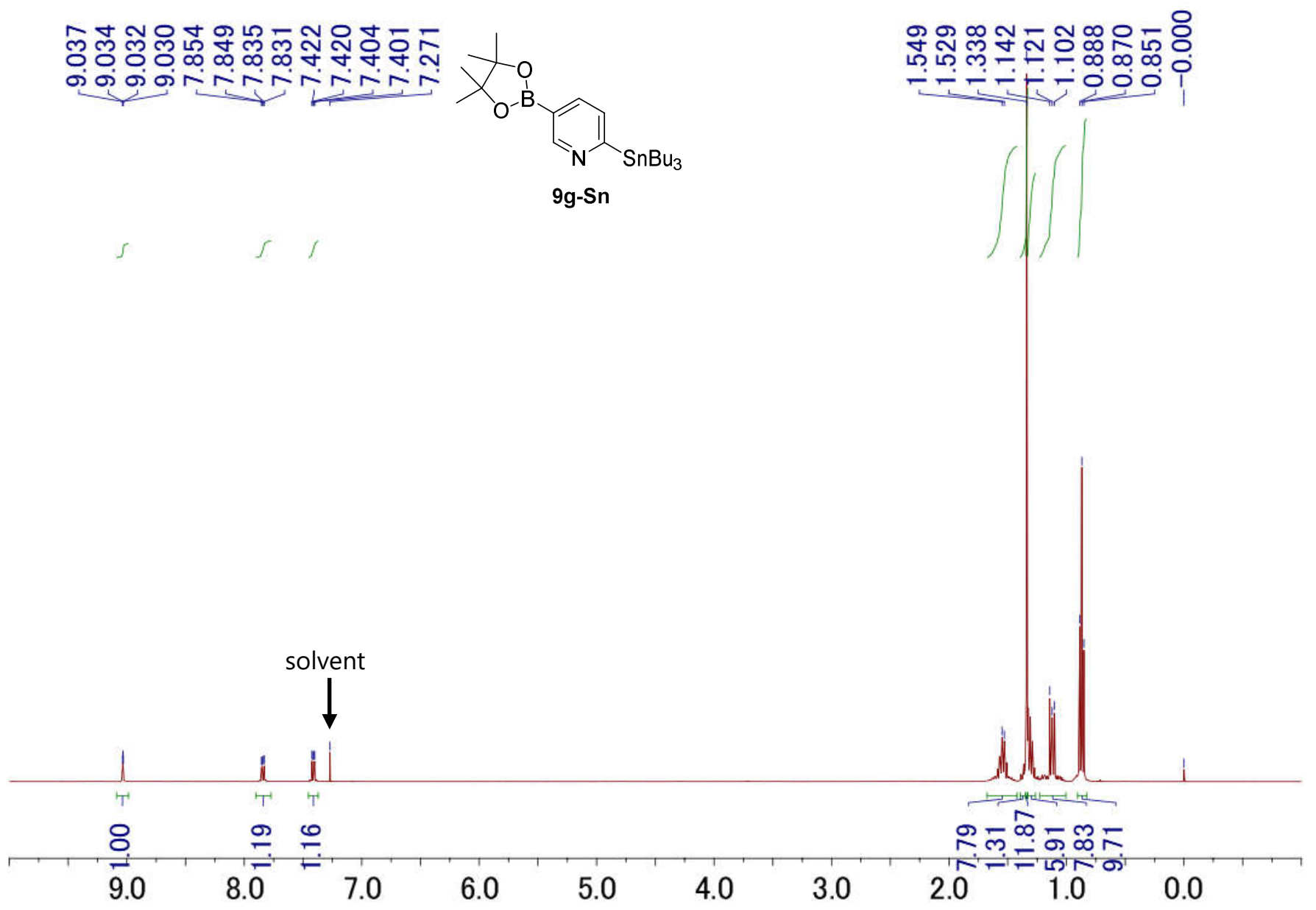

${ }^{1} \mathrm{H}$ NMR spectrum of 2-tri-n-butylstannylpyridin-5-boronic acid pinacol ester (9g-Sn) (400 $\left.\mathrm{MHz}, \mathrm{CDCl}_{3}\right)$.
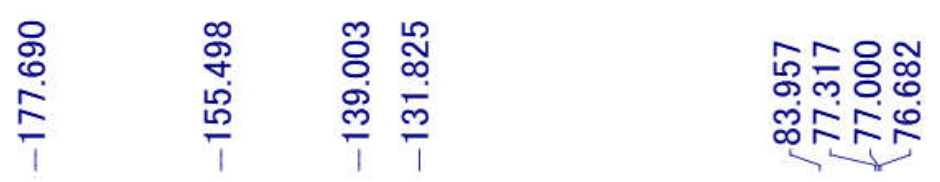

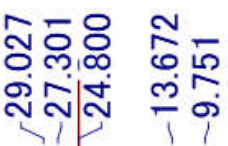

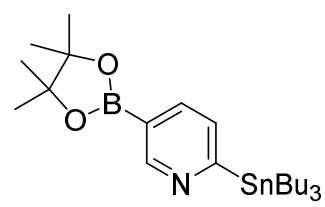

$9 g-S n$

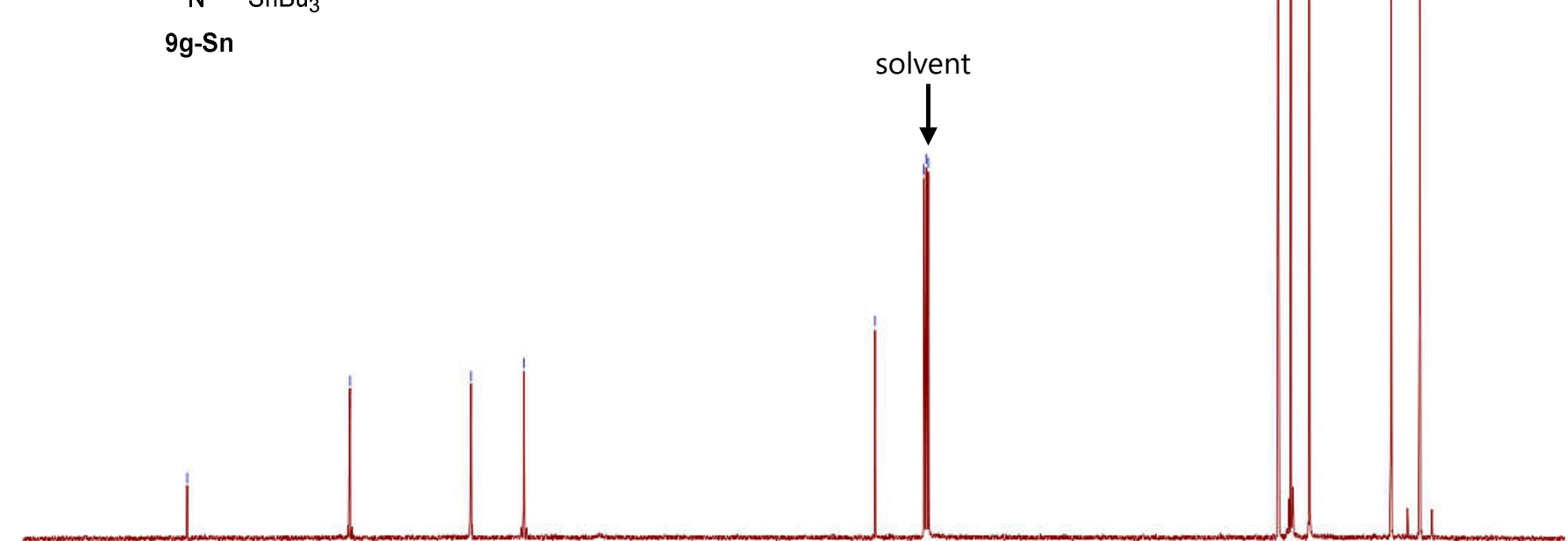

$\begin{array}{lllllllllll}00 & 180 & 160 & 140 & 120 & 100 & 80 & 60 & 40 & 20 & 0\end{array}$

${ }^{13} \mathrm{C}$ NMR spectrum of 2-tri-n-butylstannylpyridin-5-boronic acid pinacol ester (9g-Sn) (100 $\left.\mathrm{MHz} \mathrm{CDCl}_{3}\right)$. 


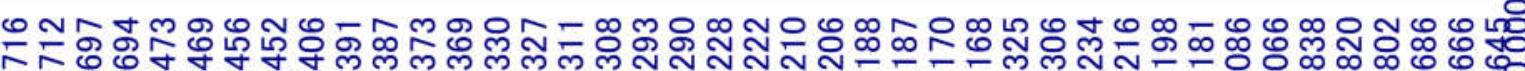

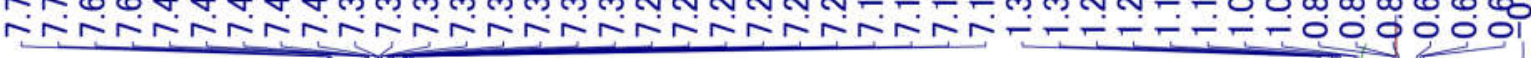
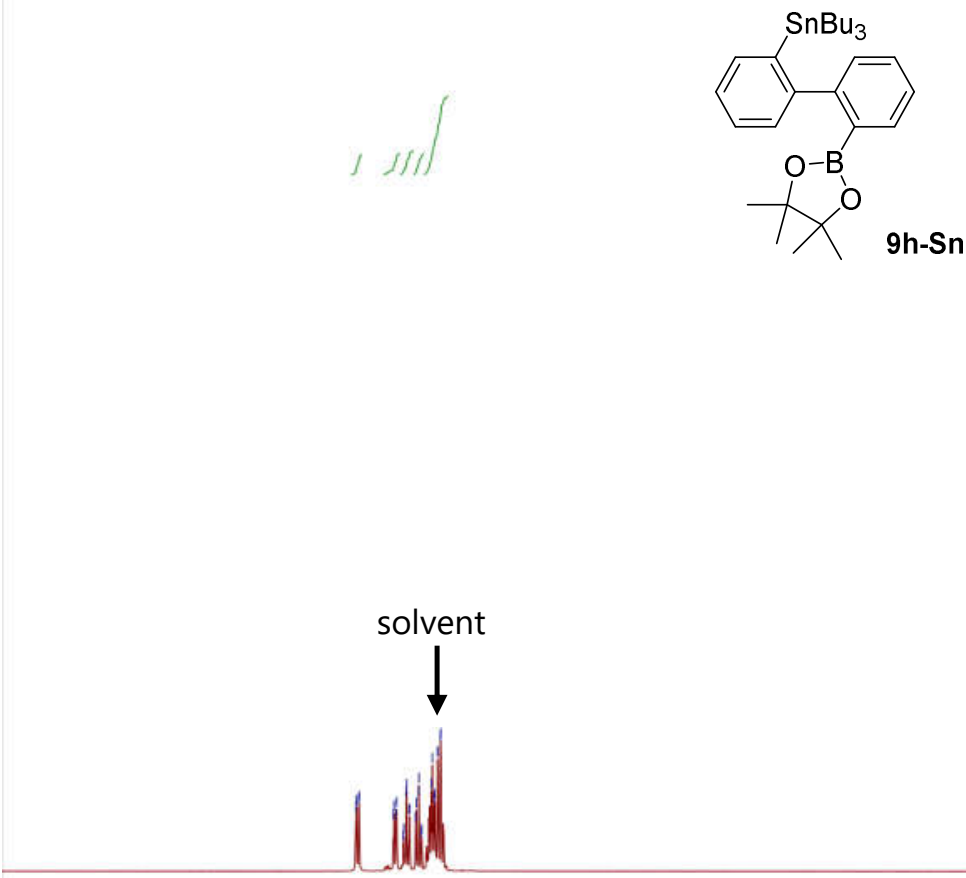

৪ะํㅇำ

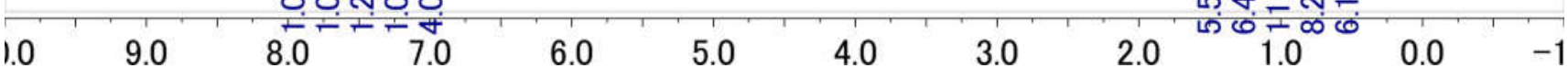

${ }^{1} \mathrm{H}$ NMR spectrum of 2'-tri-n-butylstannylbiphenyl-2-boronic acid pinacol ester (9h-Sn) (400 $\left.\mathrm{MHz} \mathrm{CDCl}_{3}\right)$.

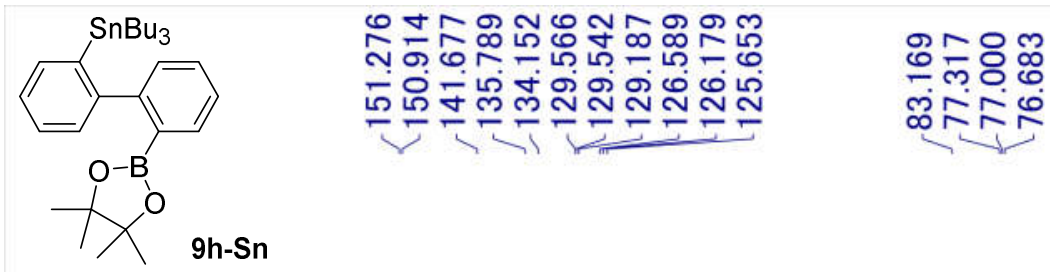

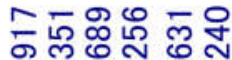

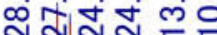

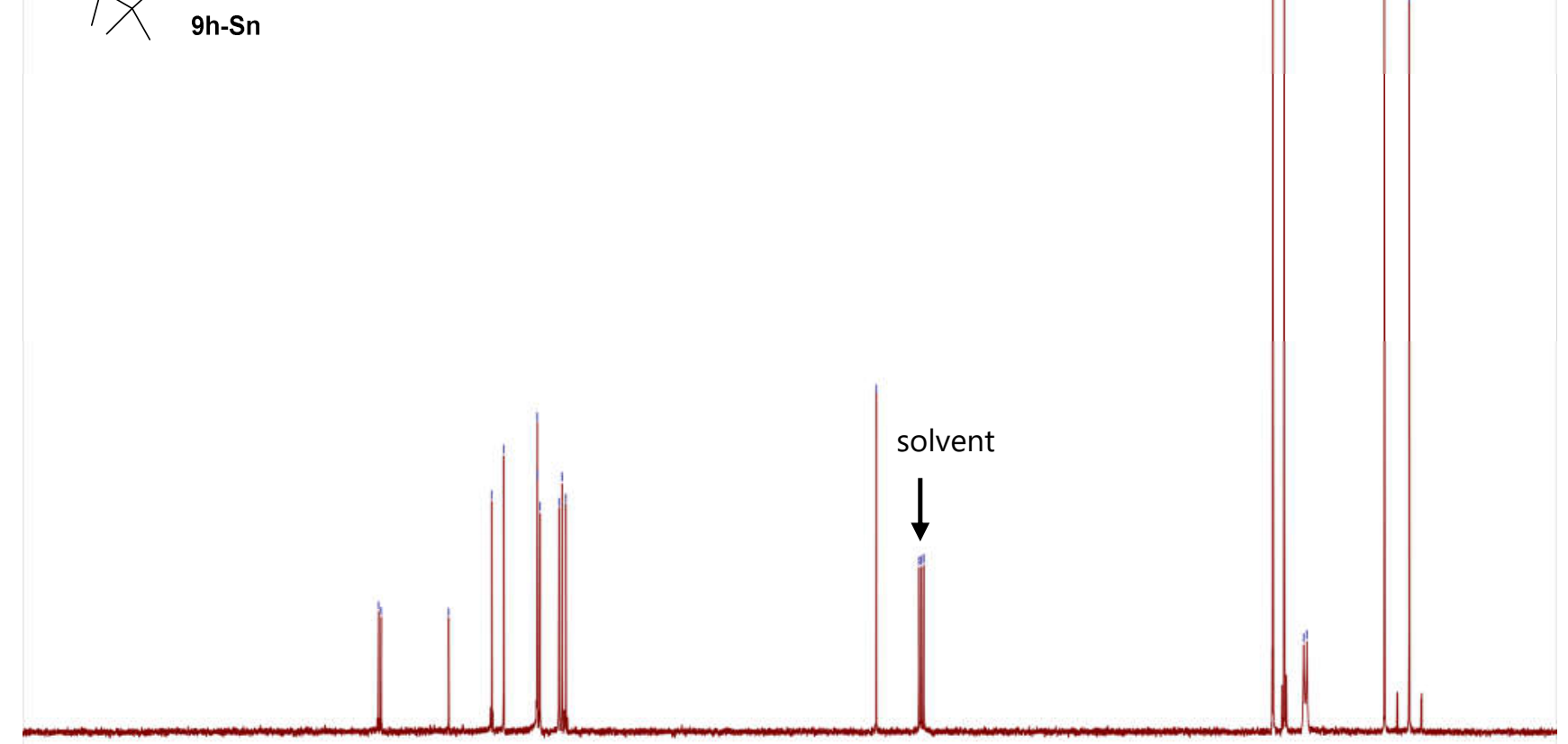

$\begin{array}{llllllllllllllllllll}190 & 180 & 170 & 160 & 150 & 140 & 130 & 120 & 110 & 100 & 90 & 80 & 70 & 60 & 50 & 40 & 30 & 20 & 10 & 0\end{array}$

${ }^{13} \mathrm{C}$ NMR spectrum of 2'-tri-n-butylstannylbiphenyl-2-boronic acid pinacol ester (9h-Sn) (100 $\left.\mathrm{MHz}, \mathrm{CDCl}_{3}\right)$. 


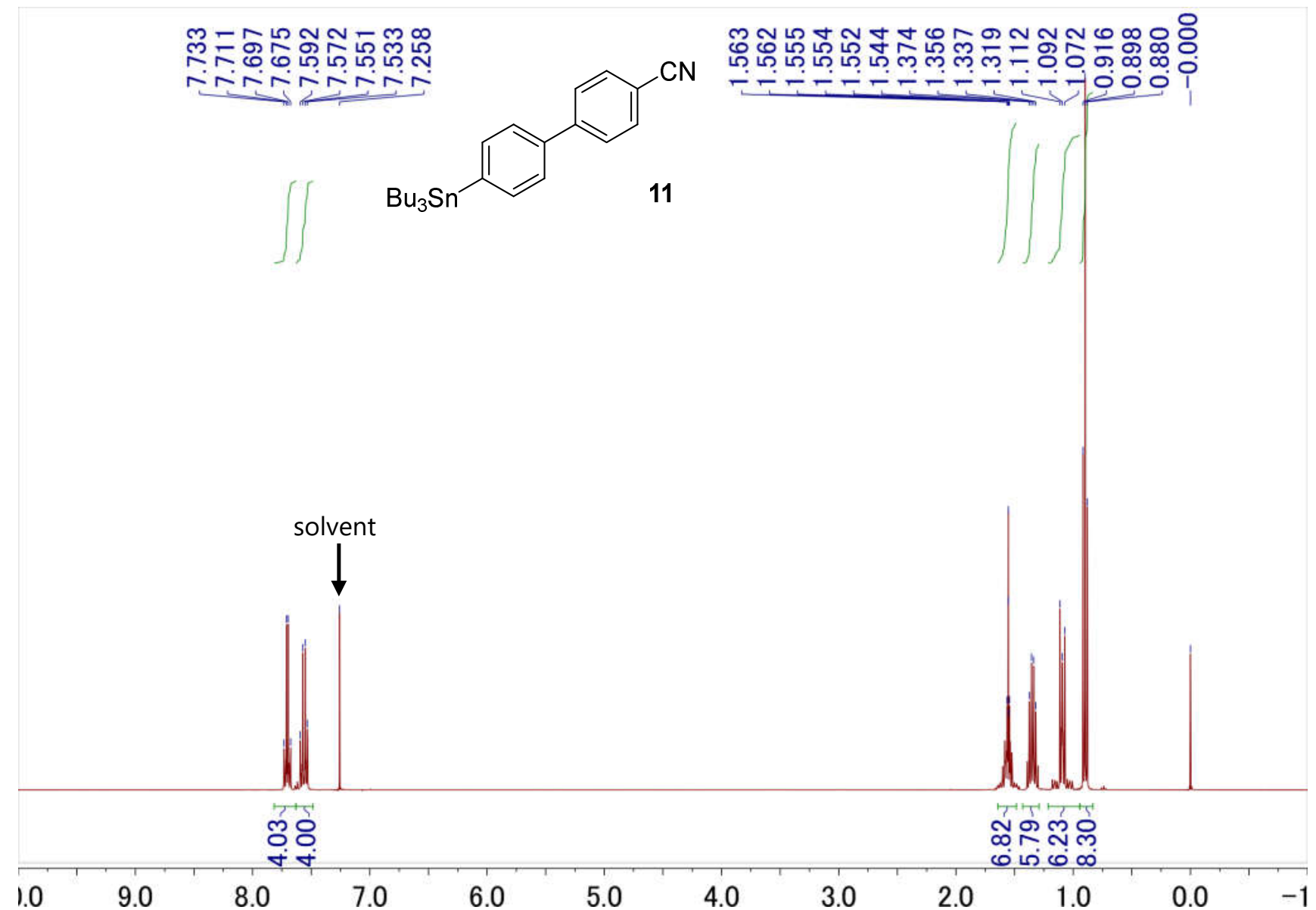

${ }^{1} \mathrm{H}$ NMR spectrum of 4-tri-n-butylstannyl-4'-cyanobiphenyl (11) (400 $\left.\mathrm{MHz}, \mathrm{CDCl}_{3}\right)$.
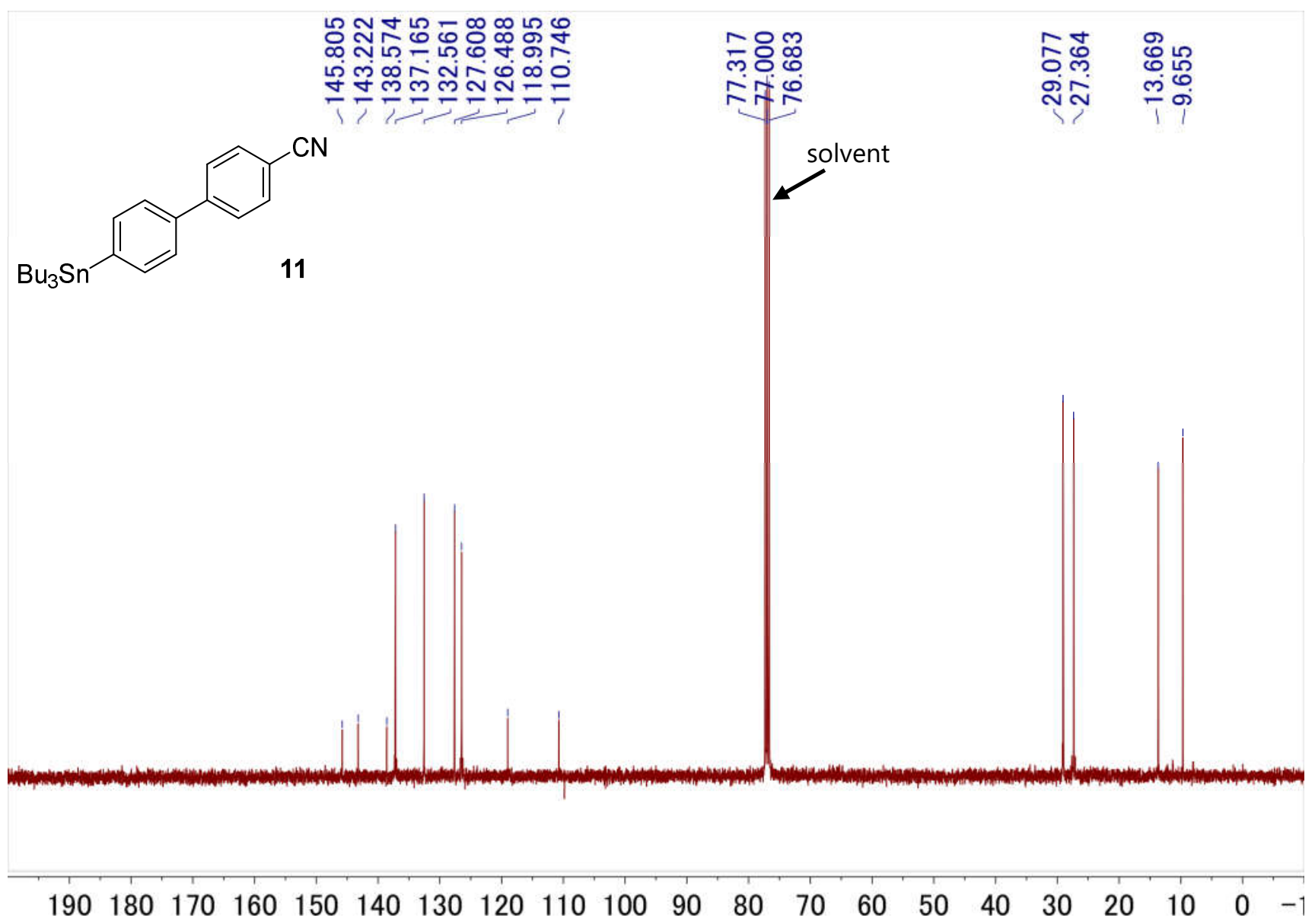

${ }^{13} \mathrm{C}$ NMR spectrum of 4-tri-n-butylstannyl-4'-cyanobiphenyl (11) (100 $\left.\mathrm{MHz}, \mathrm{CDCl}_{3}\right)$. 


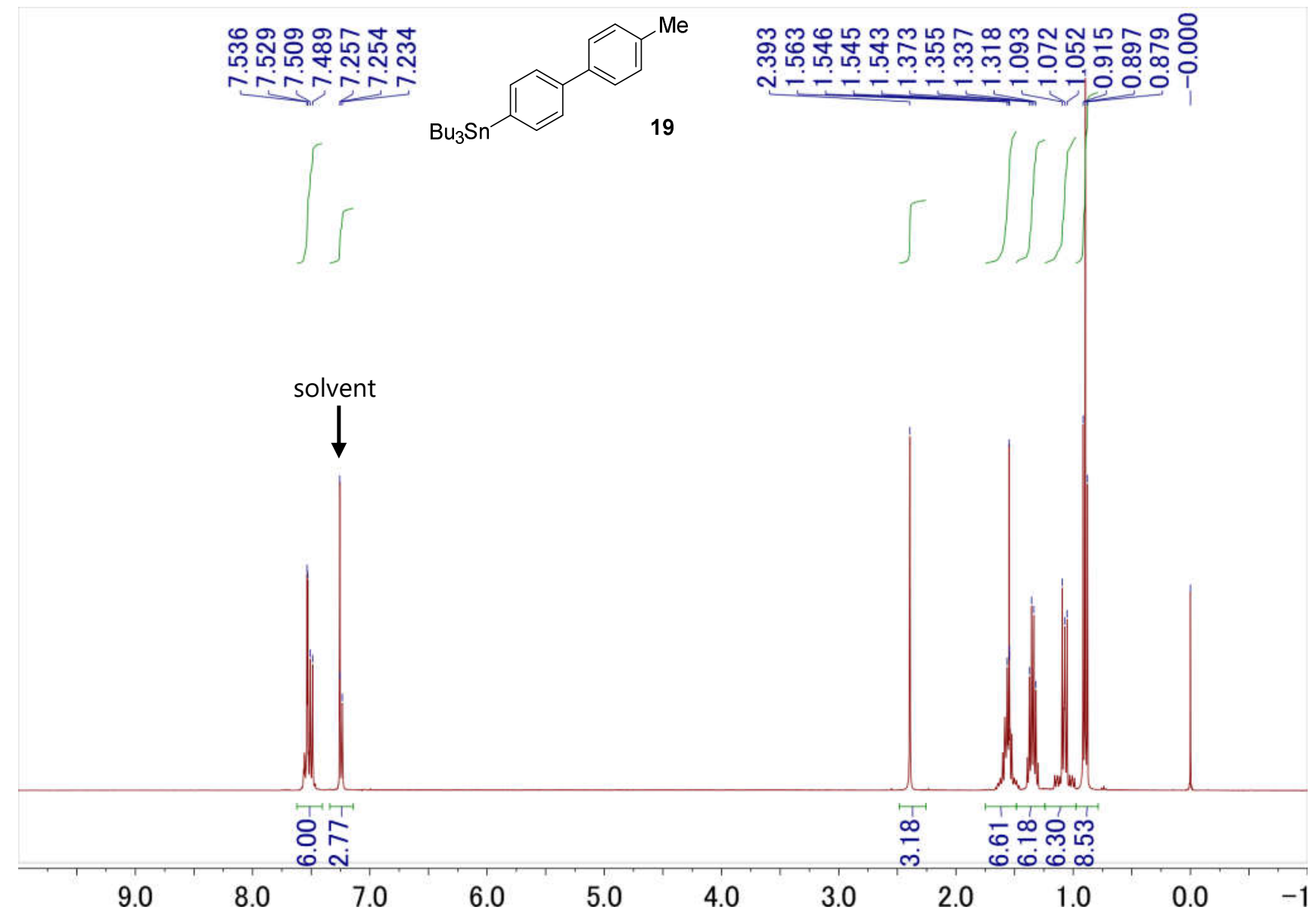

${ }^{1} \mathrm{H}$ NMR spectrum of 4-tri-n-butylstannyl-4'-methylbiphenyl (19) (400 $\mathrm{MHz}, \mathrm{CDCl}_{3}$ ).

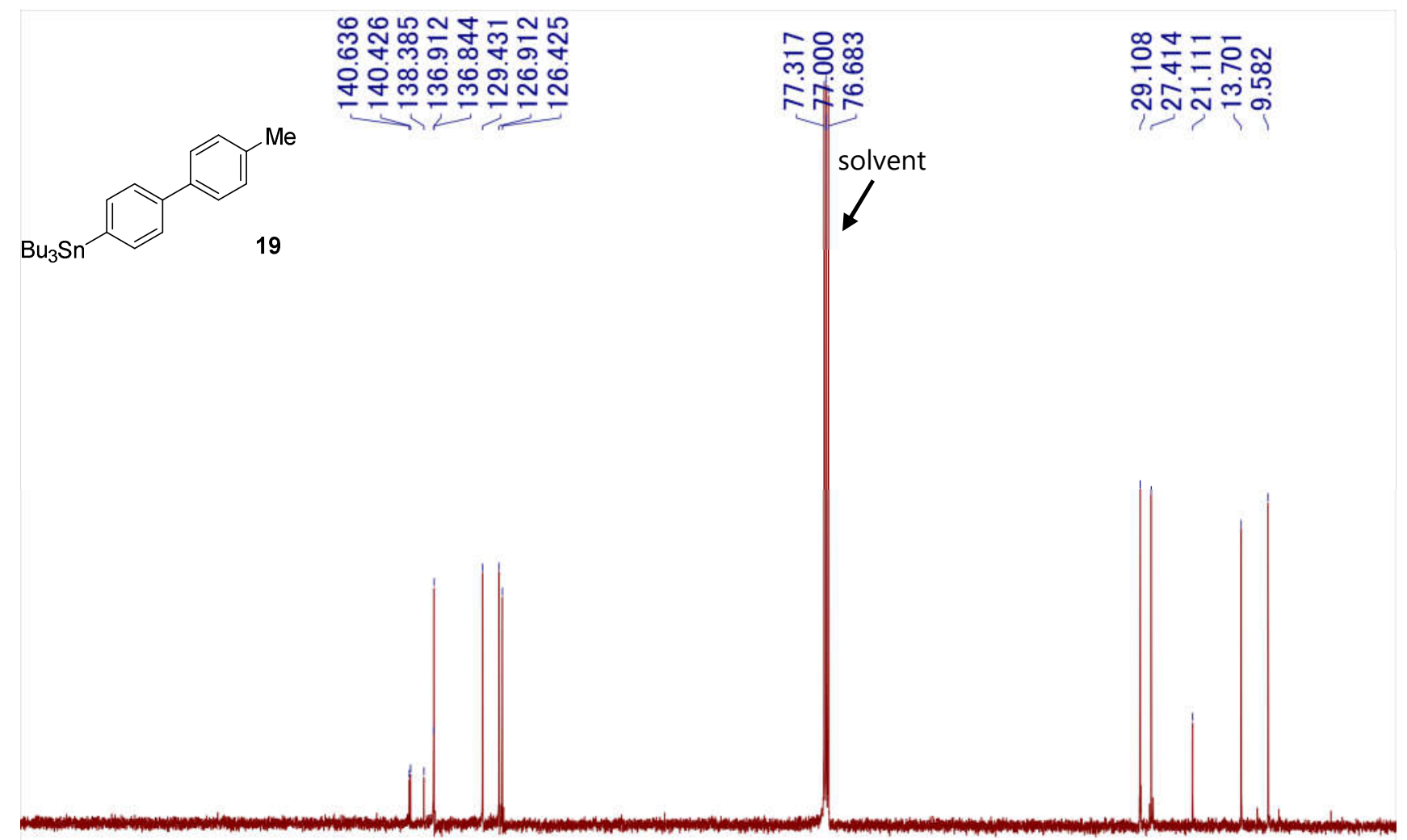

$\begin{array}{lllllllllllllllllllll}190 & 180 & 170 & 160 & 150 & 140 & 130 & 120 & 110 & 100 & 90 & 80 & 70 & 60 & 50 & 40 & 30 & 20 & 10 & 0 & -1\end{array}$

${ }^{13} \mathrm{C}$ NMR spectrum of 4-tri-n-butylstannyl-4'-methylbiphenyl (19) (100 MHz, CDCl 3$)$. 


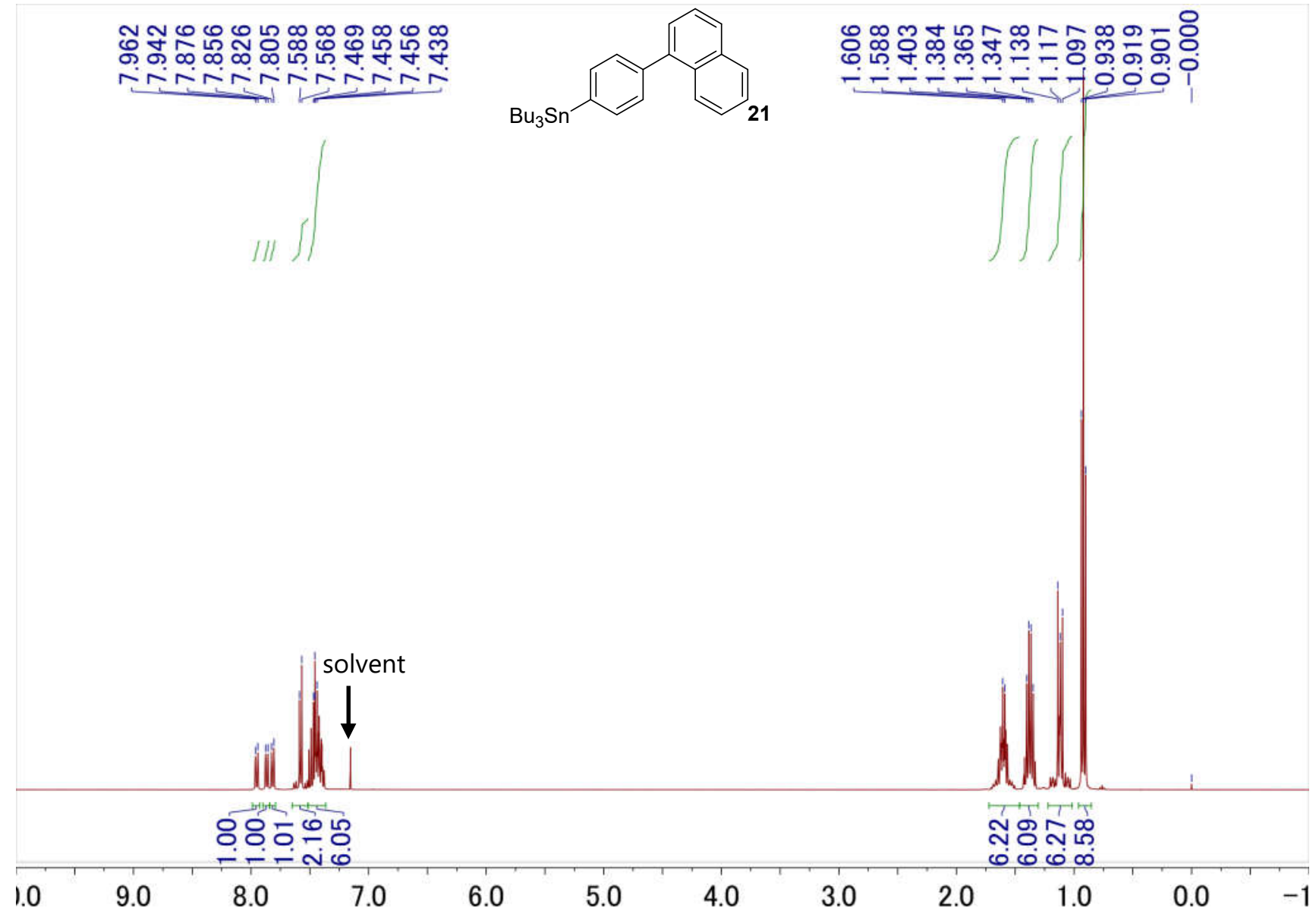

${ }^{1} \mathrm{H}$ NMR spectrum of tri-n-butyl-4-(1-naphthyl)phenylstannane (21) (400 $\mathrm{MHz}, \mathrm{CDCl}_{3}$ ).

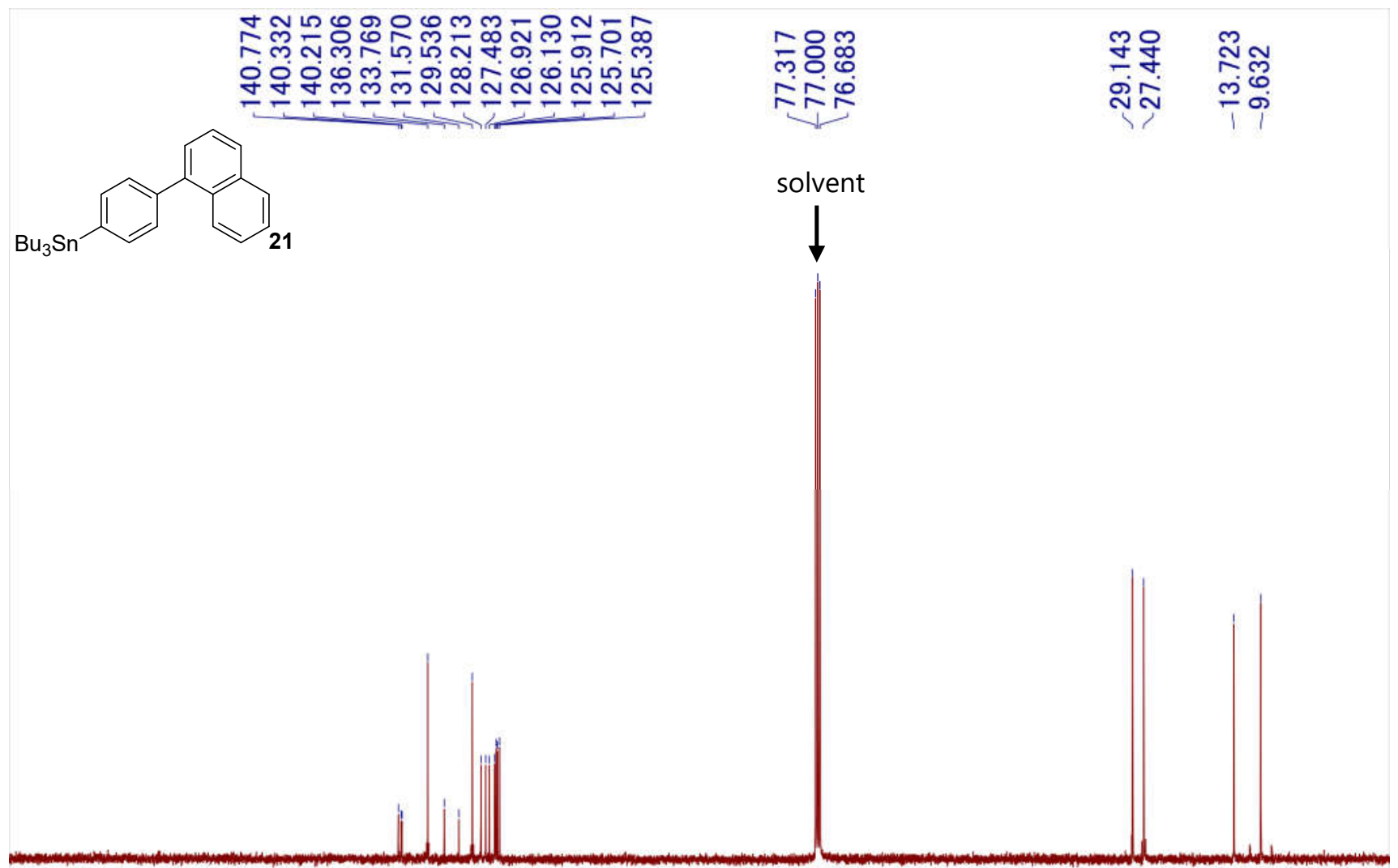

$\begin{array}{lllllllllllllllllllll}190 & 180 & 170 & 160 & 150 & 140 & 130 & 120 & 110 & 100 & 90 & 80 & 70 & 60 & 50 & 40 & 30 & 20 & 10 & 0 & -1\end{array}$

${ }^{13} \mathrm{C}$ NMR spectrum of tri-n-butyl-4-(1-naphthyl)phenylstannane (21) (100 MHz, CDCl 3$)$. 


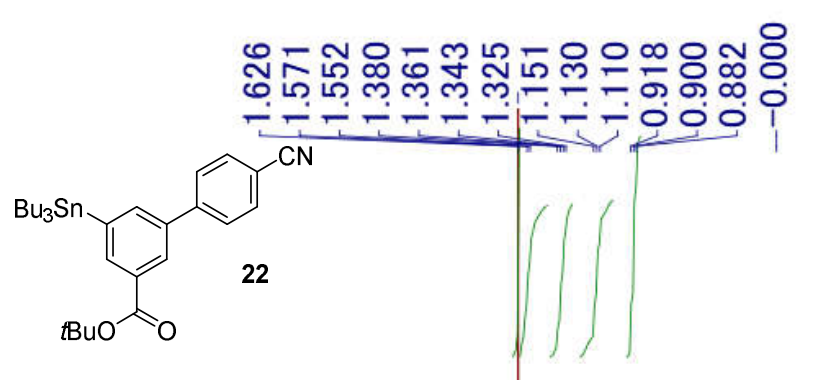

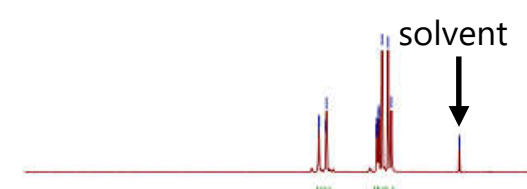

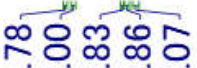

O-O-N

\section{0}

7.0

6.0

5.0

4.0

3.0

2.0

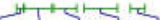

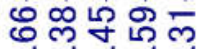

क०ण 0 \%

${ }^{1} \mathrm{H}$ NMR spectrum of 3-tert-butoxycarbonyl-5-tri-n-butylstannyl-4'-cyanobiphenyl (22) (400 $\left.\mathrm{MHz}, \mathrm{CDCl}_{3}\right)$.
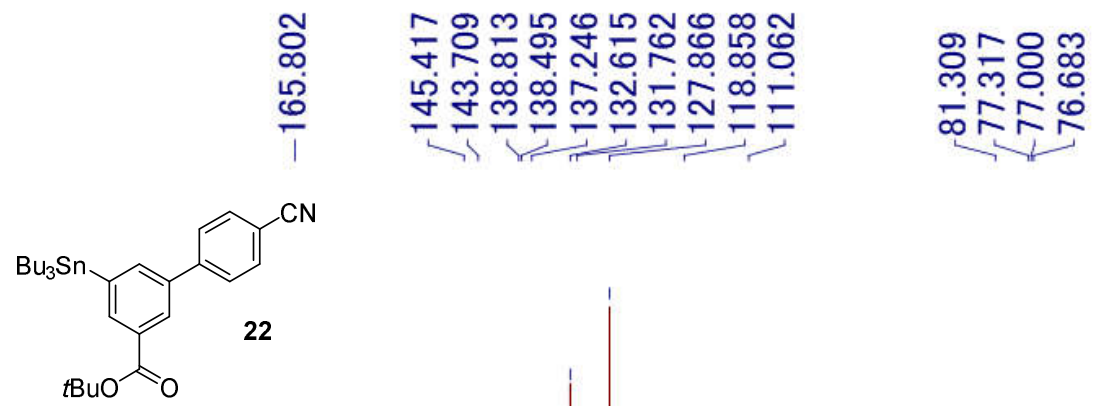

00

180

160

140

120

100

80

60

40

20

0

${ }^{13} \mathrm{C}$ NMR spectrum of 3-tert-butoxycarbonyl-5-tri-n-butylstannyl-4'-cyanobiphenyl (22) (100 $\mathrm{MHz}^{\mathrm{CDCl}}$ ). 


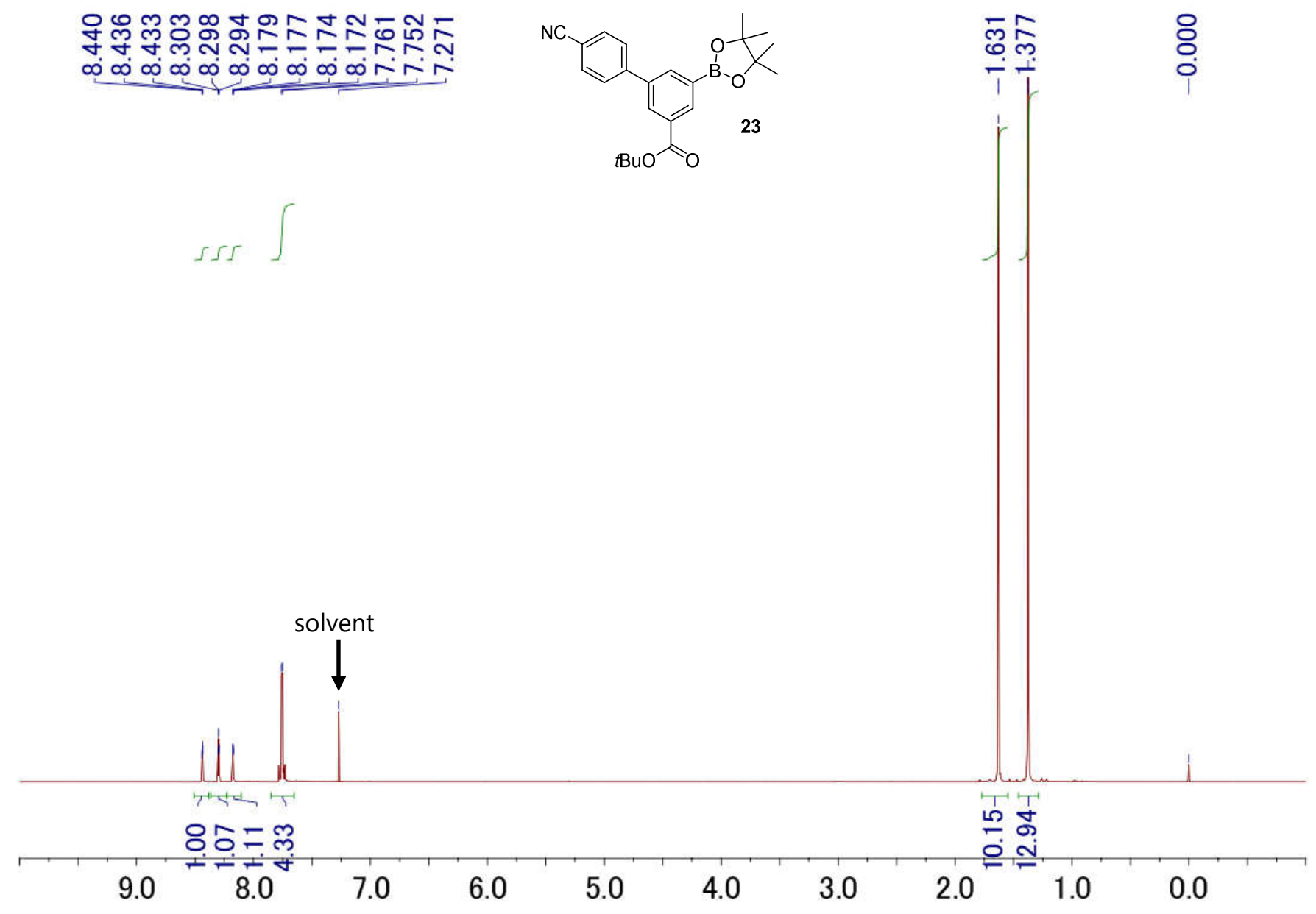

${ }^{1} \mathrm{H}$ NMR spectrum of 3-tert-butoxycarbonyl-5-(4-cyanophenyl)phenylboronic acid pinacol ester (23) (400 $\left.\mathrm{MHz}, \mathrm{CDCl}_{3}\right)$.

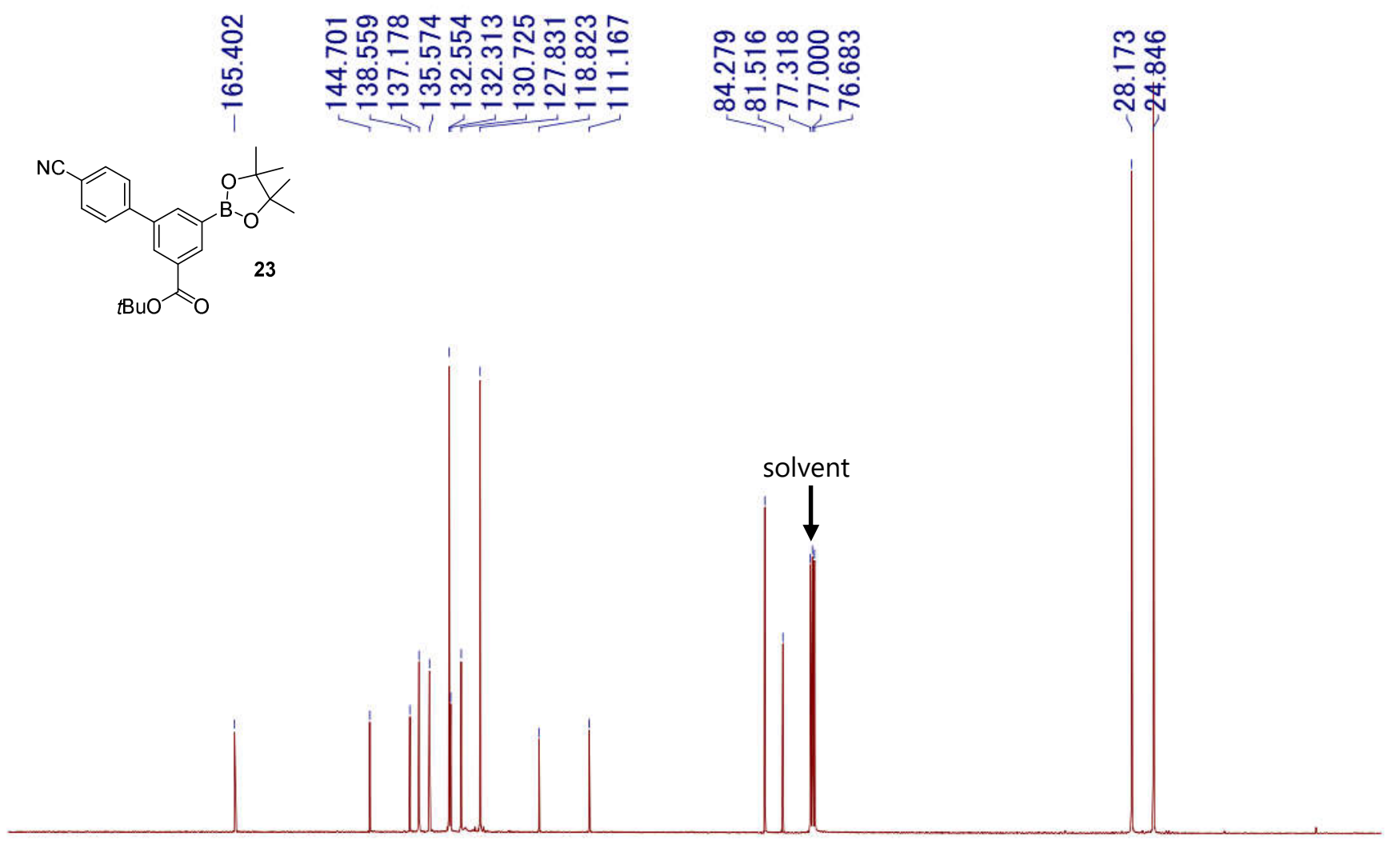

\begin{tabular}{lllllllllll}
\hline 0 & 180 & 160 & 140 & 120 & 100 & 80 & 60 & 40 & 20 & 0
\end{tabular}

${ }^{13} \mathrm{C}$ NMR spectrum of 3-tert-butoxycarbonyl-5-(4-cyanophenyl)phenylboronic acid pinacol ester (23) (100 MHz, $\left.\mathrm{CDCl}_{3}\right)$. 


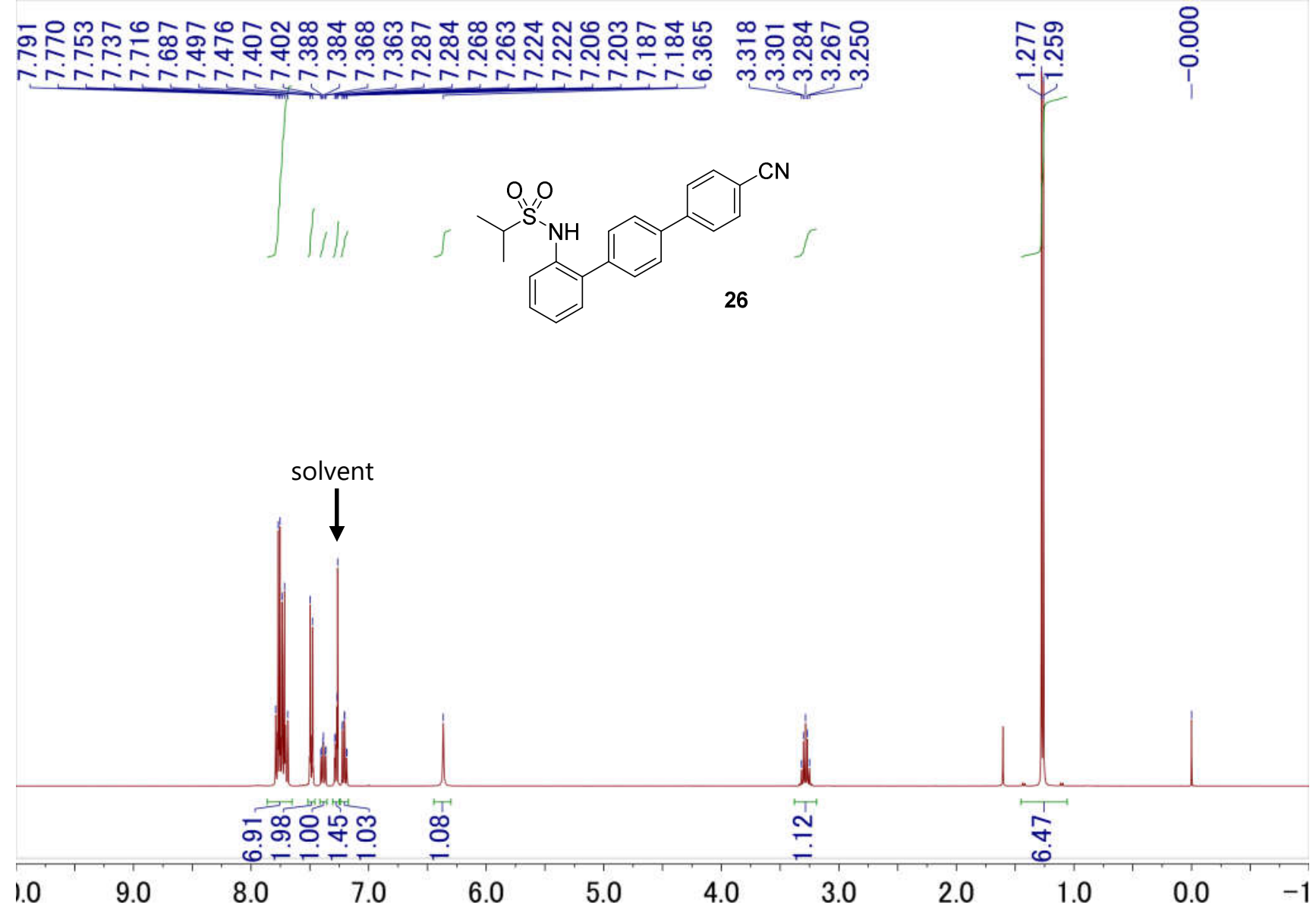

${ }^{1} \mathrm{H}$ NMR spectrum of $\mathrm{N}$-isopropyl(4"-cyano-[1,1';4',1"']terphenyl-2-yl)sulfonamide (26) (400 $\left.\mathrm{MHz}^{\prime} \mathrm{CDCl}_{3}\right)$.

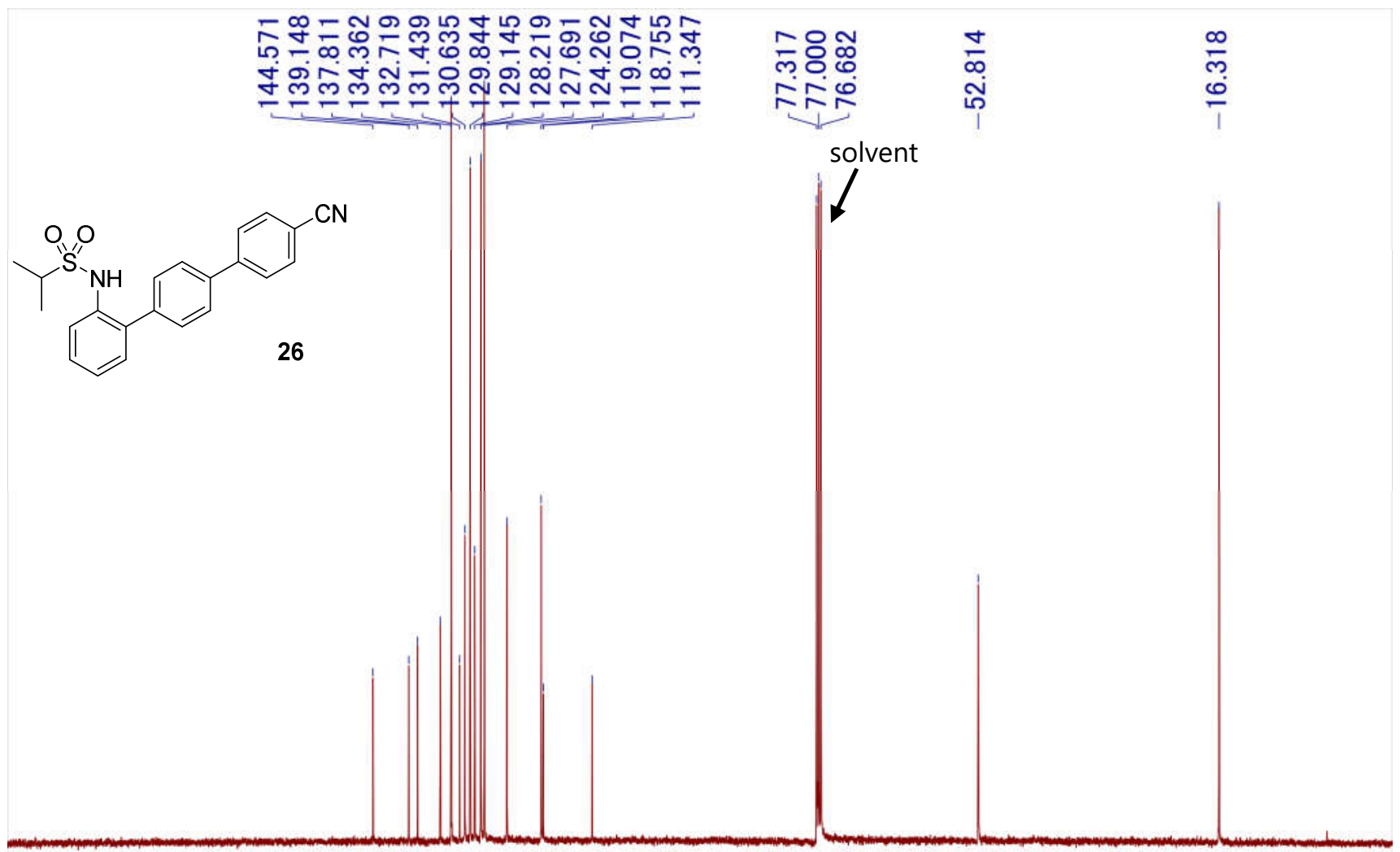

$\begin{array}{lllllllllllllllllllll}190 & 180 & 170 & 160 & 150 & 140 & 130 & 120 & 110 & 100 & 90 & 80 & 70 & 60 & 50 & 40 & 30 & 20 & 10 & 0 & -1\end{array}$

${ }^{13} \mathrm{C}$ NMR spectrum of $\mathrm{N}$-isopropyl(4"'-cyano-[1,1';4',1"']terphenyl-2-yl)sulfonamide (26) (100 $\left.\mathrm{MHz}, \mathrm{CDCl}_{3}\right)$. 